\title{
Extrañas ausencias: las fiestas marítimas en el calendario litúrgico griego
}

\author{
Mirella Romero Recio*
}

El origen de este trabajo tiene su génesis en la sorpresa que siempre me ha producido comprobar cómo existe entre los historiadores un cierto rechazo a admitir -especialmente en los últimos años- la influencia del mundo marino en la praxis religiosa de la Grecia antigua. Mientras que el consenso es absoluto a la hora de presentar al pueblo griego volcado en el mar desde una época muy antigua por la propia necesidad que imponía su medio geográfico, como quedaría plasmado en una mitología rica en dioses y héroes relacionados con este espacio, las reticencias son mayores a la hora de admitir la faceta marina que tuvieron la mayor parte de las divinidades, la protección que éstas ejercieron sobre todos aquellos vinculados de una manera u otra al mar y, por encima de todo, la presencia de elementos asociados a este medio en los rituales y fiestas religiosas.

Se recurre constantemente a los textos homéricos buscando la esencia de los dioses que se contrasta con la información que arroja la arqueología para el mundo griego de época micénica y de los siglos oscuros, pero se relega a un segundo plano el hecho de que Homero muestre, por ejemplo, a una diosa como Atenea auxiliando a Odiseo en la navegación y que los micénicos, en cuyas tablillas hemos encontrado la mayor parte de los nombres de los dioses que forman el panteón heleno, establecieran frecuentes relaciones con el mundo mediterráneo, por mar por supuesto. ¿No necesitarían la ayuda de las divinidades en este medio cuando sí la necesitaban para comerciar, conquistar nuevos territorios, cultivar sus campos o, por ejemplo, garantizar la reproducción? Y si todas estas actividades debían ser protegidas por los dioses y éstos exigían a cambio, además de culto en sus santuarios, un conjunto amplio de rituales y fiestas

* Universidad Carlos III de Madrid - mmromero@hum.uc3m.es. Este trabajo es producto de la tareas realizadas por el grupo de investigación "Historiografía e Historia de las Religiones" de la UC3 $\mathrm{M}$, reconocido y financiado por la Comunidad de Madrid. 
conmemorativas en su honor ¿por qué habrían de conformarse con menos las deidades protectoras de los navegantes? Dado que sabemos que éstas disponían de santuarios y eran veneradas por aquellos que emprendían habitual o circunstancialmente la navegación $^{1}$ ¿por qué los dioses protectores de esta actividad, de importancia vital en las comunicaciones durante la Antigüedad, habrían de contar tan sólo con dos fiestas -las Cibernesias o fiesta de los pilotos y las ploiaphesia o Navigium Isidis- a lo largo de todo el año y en todo el mundo griego? ¿no sería motivo de celebración, además del inicio y el fin de la temporada naviera, la ayuda de los dioses en los viajes marítimos tan peligrosos y al mismo tiempo imprescindibles durante la Antigüedad?

El hecho de que en las Panateneas, que es considerada una de las fiestas atenienses más antiguas y de mayor prestigio de Atenas, el peplo de la diosa Atenea se traslade en un barco no parece ser un elemento al que se otorgue demasiada importancia, al menos no en relación con la navegación. Tampoco que aparezca la procesión de un dios en otro barco, en este caso Dioniso, en otra fiesta antigua, las Antesterias de Atenas y Esmirna, es considerado un elemento que haya invitado a vincular esta fiesta de una manera especial con el mar o la navegación. Y estos ejemplos entre los más conocidos, pero sin olvidar otros muchos, como las fiestas de Ártemis Muniquia conmemorando la victoria naval en Salamina, las procesiones desde los santuarios hasta la playa donde se bañan en las aguas del mar las estatuas de diosas como la Hera de Samos, o las celebraciones, por otra parte desconocidas, vinculadas al culto de Palemón -rescatado de las aguas por un delfín- en el Istmo de Corinto, por ejemplo.

Se tiene la impresión de que, si la investigación admite el carácter marino de algunas divinidades y fiestas, está rechazando otras facetas, lo cual, como veremos, no es cierto porque casi todas son compatibles, como son compatibles las diversas advocaciones de un mismo dios. Que los Dioscuros estén vinculados a la guerra no implica que deba rechazarse su vinculación con el mar y los navegantes, algo ampliamente constatado, como no lo es que Posidón sea el dios del mar y los terremotos y los caballos.... Creo que, en general, las funciones de los dioses tienden a compartimentarse demasiado haciendo que unas excluyan a otras. Del mismo modo que, como dice Ileana Chirassi Colombo, a propósito de la religión en el mundo emergente de las poleis, "habría que hablar de muchos mitos distintos más que de una mitología; de varias "religiones" más que de una experiencia religiosa única y global” ${ }^{2}$, creo que, también, habría que hablar

I M. Romero Recio, Cultos maritimos y religiosidad de navegantes en el mundo griego antiguo, BAR 897, Oxford, 2000; J. Alvar, M. Romero Recio, «La vie religieuse en mer», Dialogues d'histoire ancienne, suppl. I, 2005, 167-189.

2 I. Chirassi Colombo, La religión griega. Dioses, héroes, ritos y misterios, Madrid, 2005, 31. 
de un número considerable de divinidades flexibles en sus atribuciones que ejercen, cada una de ellas, su protección, sobre un número aún más extenso de ámbitos que pueden ser bien diferentes entre sí.

Y esto, evidentemente, afecta a las fiestas en honor de estos dioses. Como trataré de mostrar a lo largo de este trabajo, que una fiesta sea fundamentalmente agraria no impide que pueda tener elementos relacionados con el mar y la navegación. En primer lugar, porque se trata de festividades asociadas a la fertilidad y también se busca la "fertilidad" en el mar y, en segundo lugar, porque que el hecho de que sean agrarias cuando las conocemos a través de fuentes textuales o arqueológicas no impide que en su génesis se mezclasen elementos muy variados y mucho menos delimitados de lo que estarán a posteriori y desde luego, mucho menos que como se empeñan en mostrar algunos investigadores actuales tan dados a los compartimentos estanco. Por ejemplo, existe un especial empeño en defender el carácter agrario de las Oscoforias pasando por alto que el aition de esta festividad era la llegada de Teseo y la muerte de Egeo arrojándose al mar -e incluso toda la aventura cretense- lo que provocaba el duelo de los asistentes, y que la fiesta se realizaba como charisterion en honor de Dioniso y Atenea, según Proclo, o de Dioniso y Ariadna según Demón, deidades sobradamente relacionadas con el mar y los viajes. No comprendo, por tanto, y más adelante abundaré en ello, por qué se niega todo derecho de representación al elemento marino en esta fiesta directamente vinculada al retorno de Teseo desde Creta.

Así pues, las cuestiones que se pueden plantear a la hora de abordar este tema son numerosas y de diferente índole, pero tres de ellas me parecen especialmente interesantes y sugerentes:

1. ¿realmente en el calendario religioso ateniense no hubo apenas espacio para fiestas relacionadas con el mar y la navegación? o

2. ¿el propio rechazo de los griegos a la actividad marítima encontró reflejo en sus fuentes escritas que infravaloraron o ignoraron la faceta marina de sus fiestas? o

3. ¿tal vez haya sido la historiografía contemporánea la que ha infravalorado la actividad marítima/comercial -y, en consecuencia, la dimensión marina de las fiestas del calendario litúrgico- ejercida por una clase social que no podía competir con la aristocracia, propietaria de la tierra y, por tanto, promotora de una actividad mucho más digna, la agricultura -perfectamente representada en el calendario? Este tipo de prejuicios han sido denunciados por otros autores a propósito de variadas cuestiones, entre ellas, también el comercio ${ }^{3}$.

3 Véanse, por ejemplo, los artículos de M.E. Aubet, «El comercio fenicio en Homero», en S.F. Ramallo Asensio (ed.), Estudios de arqueología dedicados a la profesora Ana Ma Muñoz Amilibia, Murcia, 2003, 99, y J. Alvar, «El contraideal del comercio: entre la ficción histórica y el uso historiográfico», en D. Plácido 
Por tanto, y descartando la respuesta afirmativa a la primera cuestión planteada, creo que puede relacionarse la posible vinculación de algunas fiestas con la guerra o el reclutamiento, por ejemplo, con la valoración positiva que se hace de la navegación en las fuentes escritas cuando ésta se relaciona con la actividad bélica -no con la comercial- y, sobre todo, con el éxito en las batallas navales. Humphreys ya ha subrayado que a la hora de estudiar las festividades del mundo griego no debemos olvidar que, en su mayor parte, se trata de rituales muy antiguos que van sufriendo diferentes cambios a lo largo del tiempo ${ }^{4}$, por lo que no podemos ofrecer una interpretación monolítica de las mismas.

Así pues, creo que las conexiones con el mar y la navegación que aparecen en algunas celebraciones antiguas podrían tener su origen en un momento -del que poseemos escasos documentos escritos- en el que no existía una diferencia neta entre guerra/piratería-comercio prexis ${ }^{5}$. Ambas actividades estarían entonces íntimamente relacionadas, se desarrollarían con los mismos objetivos -obtención de recursos- y sus protagonistas serían los mismos -los aristócratas. Sin embargo, durante la época arcaica se habría producido una separación entre actividad bélica en el mar y actividad comercial. Creo que, como trataré de exponer, el motivo "naval" de las fiestas perderá entonces protagonismo pues ya no se vinculará directamente con la armada y sí con el movimiento comercial. Tal vez por eso las Cibernesias no son fiestas ni muy conocidas, se sabe poco de ellas, ni de amplia participación ciudadana. Sí son, por el contrario, mucho más frecuentadas otras como la celebrada en honor de Ártemis Muniquia en conmemoración de la victoria de Salamina, festividad que por otra parte, como veremos, parece tener relación con la actividad marítima desde una época anterior según muestra, entre otras cosas, la iconografía sobre Teseo. Pero es que además, algunas fiestas podrían haberse relacionado, en principio, con cultos privados de familias aristocráticas -cuando la posesión de barcos estaba en manos de los aristoi que las

\footnotetext{
et alii, La construcción ideológica de la ciudadanía. Identidades culturales y sociedad en el mundo griego antiguo, Madrid, 2006, 179-186. Sin duda uno de los ataques más directos y polémicos contra modelos generados por la historiografía fue el realizado por M. Bernal: Atenea negra: las raíces afroasiáticas de la civilización clásica. .I. La invención de la Antigua Grecia: 1785-1985, Barcelona, 1993; Black Athena. The Afroasiatic Roots of Classical Civilization. II. The Archaeological and Documentary Evidence, Londres, I991; Black Athena writes back. Martin Bernal responds to his critics, S.C.H. Moore (ed.), Londres, $200 \mathrm{I}$. 4 S.C. Humphreys, The Strangeness of Gods. Historical perspectives on the interpretation of Athenian religion, Oxford, 2004, 223.

5 Siguiendo a A. Mele en su ya clásico Il commercio Greco Arcaico, Praxis ed emporie, Nápoles, 1979, trabajo que fue replicado por B. Bravo, «Remarques sur les assises sociales. Les formes d'organisation et la terminologie du commerce maritime grec à l'époque archaïque», $D H_{3}, 1977, \mathrm{I}-59$
} 
empleaban en sus razzias y también como medio de obtención de riquezas- que después entrarían en la esfera pública y se convertirían en cultos oficiales bien cambiando alguno de sus rituales originarios o bien perdiendo u olvidando su carácter primigenio. Será por tanto también necesario tener en cuenta que, como han destacado algunos especialistas, entre la época arcaica y clásica el emporion deja de ser un espacio controlado por las aristocracias que ejercen un comercio basado en la amistad y el hospedaje, para convertirse en un establecimiento altamente burocratizado y visitado por comerciantes profesionales, lo cual evidentemente debía afectar a los cultos allí desarrollados ${ }^{6}$.

Por lo que se refiere al tercer interrogante, creo que resulta necesario al menos cuestionarse por qué existe una tendencia a minimizar el papel de los cultos marítimos y sobre todo de las festividades asociadas a los mismos si, como presumo, existen datos que apuntan en otra dirección.

Sobre éstas, fundamentalmente, pero también sobre otras cuestiones, girará el presente trabajo.

\section{Fiestas vinculadas al mar}

Como ya he adelantado, dos son las fiestas que se vinculan sin dificultad al mar y la actividad náutica: las Cibernesias y las Ploiaphesia o Navigium Isidis.

\section{I.I. Cibernesias}

Según Plutarco -siguiendo a Filócoro (FGrH 328 F i8)-, Teseo había tomado en casa de Esciro en Salamina al piloto (kybernetes) y al jefe de proa o vigía (proreus) -Nausítoo y Feacio- que le acompañarían en su viaje a Creta ${ }^{7}$. A su regreso, el héroe había erigido en honor de éstos un monumento en Falero, donde se les rendía culto junto a Esciro, e instituido en su honor las Cibernesias o fiesta de los pilotos ( $F G r H$ 328 F III = Plu. Thes. 17.6-7). Más adelante Plutarco también cuenta (Thes. 23.I; cf. Call. Del. 314) que el barco con el que Teseo viajó a Creta se guardó en Atenas hasta la

6 P. Dupont, «Trafics méditerranéens archaïques: quelques aspects», F. Krinzinger (ed.), Die Ägäis und das Westliche Mittelmeer. Beziehungen und Wechselwirkungen 8. bis 5. Jh. V. Chr., Viena, 2000, 445; A. Domínguez Monedero, «La Religión en el emporion», Gerión, 19, 2001, 223 ss.

7 Paus. I.35.3. Sobre los puertos del Ática, incluido el de Salamina: Psd. Scyl. 57 GGM. Al sur de la isla se ha localizado un puerto que debió de ser operativo desde época micénica, véase, Y.G. Lolos, «Notes on Salaminian harbours», en H. Tzalas (Ed.), Tropis III. $3^{\text {rd }}$ International Symposium on Ship Construction in Antiquity, Athens 1989, Atenas, 1995, 291-308. Sobre el Teseo de Plutarco: C. García Gual, «El mito de Teseo en Isócrates y Plutarco», en R. Olmos (coord..), Coloquio sobre Teseo y la copa de Aison. Anejos del Archivo Español de Arqueología, I2, Madrid, 1992, 217-226. 
época de Demetrio Falereo, a pesar de que era necesario realizar constantes labores de restauración. C. Calame no duda en vincular esta ofrenda, que debió de ser presentada en Falero junto con los monumentos del piloto y el proreo a la vuelta del héroe, con la fundación de las Cibernesias y con el barco que se utilizaba en la theoria delia ${ }^{8}$. Es importante tener en cuenta que, tanto en Grecia como en Roma, existió la costumbre de conservar aquellas naves que hubiesen prestado un especial servicio a la comunidad o que hubiesen pertenecido a algún personaje ilustre? ${ }^{9}$ También en Atenas una de las trirremes sagradas llevaba el nombre del héroe ático Páralo, hijo de Posidón e inventor de las naves de guerra ${ }^{\mathrm{IO}}$.

La noticia de Plutarco sobre la fundación de las Cibernesias se ha vinculado a la inscripción del decreto del genos de los salaminios (363/362 a.C.) donde se menciona el sacrificio de un cerdo a Posidón Hippodromios -cuyo espacio sacro no ha sido localizado-, y de cochinillos en honor de Phaeax, Teucer y Nauseiros en Boedromión (septiembre/ octubre $)^{\text {II }}$; asimismo, se destaca la ofrenda de una oveja preñada a Atenea Escírada y un carnero a Esciro en Maimacterión (noviembre/diciembre) ${ }^{12}$. El héroe Phaeax es con toda probabilidad el proreo de Teseo, Feacio, y Nauseiros podría ser el piloto Nausítoo, al que también se conocería con este nombre más común por coincidir con el del primer rey de los feacios en la Odisea $^{13}$. Por otra parte, dos sacrificios celebrados en honor de Posidón también en Boedromión, y uno de ellos en Sunio, se mencionan también en el calendario de Tórico -una de las doce poleis que, según Filócoro, fueron fundadas por

8 C. Calame, Thésée et l'imaginaire athénien. Légende et culte en Grèce antique, Lausana, 1990, 127, I 48 ss.; F. Salviat, «Le bateau de Thésée, le vase François et les Triacontoroi», en H. Tzalas (Ed.), Tropis

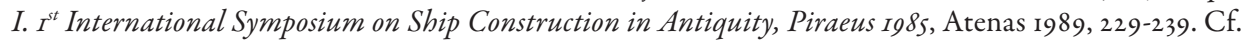
Pl. Cri. 43d; Phd. 58a-b; Xen. Mem. 4.8.2; Plu. Thes. 23.I; Paus. I.31.2.

9 Sobre esta cuestión y la ofrenda de barcos: Romero Recio, Cultos marítimos ..., 2-22.

Io Plin. nat. 7.56, 207; 35.I0I; Cic. Verr. 4.60.135; schol. Dem. 8.29; 21.570. Cf. Th. 3.33; 8.73-74, 86.

II W.S. Ferguson, «The Salaminioi of Heptaphylai and Sounion», Hesperia 7, 1938, I-5, n. I, 1. 21-22, 4I-50, 6I-65; F. Sokolowski, Lois sacrées des cités grecques (LSCG), París, 1962, n. 19, 1. 90 y 92. Cf. R. Parker, Athenian Religion: A History, Oxford, 1996, 57-59. E. Kearns (The Heroes of Attica, Londres, 1989, 38-40) encuentra dificultades en esta identificación y prefiere pensar en una manipulación de los mitos para estrechar los lazos entre los héroes salaminios y los atenienses. Sobre la actividad cultual de los salaminios y sus "reivindicaciones" territoriales a través de fiestas como las oscoforias: R. Osborne, «Archaeology, the Salaminioi, and the Politics of Sacred Space in Archaic Attica», en S.E. Alcock, R. Osborne (Eds.) Placing the Gods. Sanctuaries and Sacred Space in Ancient Greece, Oxford, 1994 (reimpr. 200I), I 43-160. I2 Ferguson, «The Salaminioi of Heptaphylai...», I-5, n. I, 1. 2I-22, 4I-50, 6I-65; Sokolowski, LSCG, n. $19,1.90$ y 92 .

13 Od. 6.7; 7.56, 62; 8.564. Según otras tradiciones, Nausítoo habría sido un hijo de Odiseo y Calipso (Hes. Theog. I017) o de Odiseo y Circe (Hyg. Fab. 125). 
el mítico rey del Ática Cécrope ${ }^{14}$, cuya tradición algunos autores han hecho remontar hasta época micénica ${ }^{15}$, y que la arqueología ha datado en el s.X a.C. ${ }^{16}$-, que se ha fechado entre el 440-430/430-420 a.C. según unos investigadores, y entre el 380-375 a.C. según $\operatorname{otros}^{17}$. Debemos tener en cuenta que, como ya señalase E. Vanderpool, existe una estrecha relación entre los cultos de Sunio -considerado ya como un promontorio de Atenas en Od., 3.278- y Tórico, y especialmente en torno a Posidón ${ }^{18}$.

Como decía, en el decreto de los salaminios se menciona una ofrenda a Atenea Escírada y Esciro, y Plutarco contaba que Teseo había reclutado a Feacio y Nausítoo en la casa de Esciro en Salamina. En la zona costera que engloba Ática, Salamina, Eleusis y Nisea (Mégara) se tejió una red de correspondencias simbólicas y rituales en torno a Teseo, personajes con el nombre de Esciro ${ }^{19}$, héroes navegantes y cultos relacionados con Atenea ${ }^{20}$. Pausanias cuenta que cuando los de Eleusis hacían la guerra contra Erecteo, les llegó un adivino de Dodona llamado Esciro, el cual erigió en Falero -de nuevo el antiguo puerto de Atenas- el santuario de Atenea Escírada ${ }^{21}$. Otra versión decía que había sido Teseo quien había moldeado la imagen de Atenea con arcilla blanca

I4 FGrH 328 F 94; Str. 9.I.20. Cf. M. Moggi, I sinecismo interstatali Greci, Pisa, 1976, I-10, 44 ss.

I5 C.G. Thomas, «Theseus and Synoicism», Studi Micenei ed Egeo Anatolici, 23, 1983, 337-349; J.M. Hurwit, The Athenian Acropolis. History, Mythology, and Archaeology from the Neolithic era to the Present, Cambridge, 1999, 79.

I6 J.N. Coldstream, Geometric Greece, Londres, 1977, 35, 78; A.M. D’Onofrio, «Sanctuari “rurali” e dinamiche insediative in Attica tra el protogeometrico e l'orientalizzante (1050-600 a.C.)», B. D'Agostino, D. Ridgway (Eds.), AПOIKIA, Scritti in onore di Giorgio Buchner, Annali di Archeologia e Storia Antica, N.S. I, Nápoles, 1994, 69, 86; « The $7^{\text {th }}$ century B.C. in Attica: the Basis of Political Organization», Urbanization in the Mediterranean in the $9^{\text {th }}$ to the $6^{\text {th }}$ Centuries B.C., Acta Hyperborea, 7, 1997, 63-88.

17 SEG, XXXIII.r47; G. Daux, «Le calendrier de Thorikos au Musée J. Paul Getty», $A C$, 52, 1983, 152-154, L. 19-20, 23-24; E. Lupu, Greek Sacred Law. A collection of New documents, Leiden-Boston, 2005, I2I-I22, I33-I34.

I8 E. Vanderpool, «A South Attic Miscelany», en H. Mussche, P. Spitaels, F. Goemaere-De Poerck (eds.), Miscellanea Graeca I: Thorikos and the Laurion in Archaic and Classical Times: papers and contributions of the colloquium held in March, 1973, at the State University of Ghent, Ghent, 1975, 33 ss.

19 O. Jahn, «Theseus, Skiron und Sinis», Archäologische Zeitung, 1865-1866, 22-31; Kearns, The Heroes of Attica, 197-198.

20 F. de Polignac, «Divinités régionales et divinités communautaires dans les cités archaïques», en V. Pirenne-Delforge (ed.), Les Panthéons des cités des origines à la Périégèse de Pausanias, (Kernos supp. 8), Lieja, 1998, 28-32.

21 Paus. I.I.4, 36.4. IG II $^{2} .1236,1$. 15-16, 23; Ferguson, «The Salaminioi of Heptaphylai...», I-5, n. I, 1. 8-IO, 5I-52. Volveremos a mencionar este santuario al abordar la fiesta de las Oscoforias en las que el templo de Atenea era el destino de la procesión. 
-precisamente el color que se atribuye a las divinidades fosfóricas de los navegantes en los promontorios $\operatorname{costeros}^{22}$ - y había construido el templo de la diosa en Falero ( $E M$, 718.6). En un promontorio de la propia Salamina había un templo de Atenea Escírada ${ }^{23}$ y Plutarco alude a un promontorio salaminio llamado Esciradio hacia donde se dirigió Solón cuando iba a conquistar la isla (Plu. Sol. 9.6-7). En Mégara, Escirón tiraba al mar a los extranjeros hasta que él mismo fue arrojado a las aguas por $\mathrm{Teseo}^{24}$, pero también en esta ciudad estaba la roca de Atenea Etía (Ai[quia) ${ }^{25}$, donde se encontraba el heroon de Pandión (Paus. I.5.3, 41.6). Estas correspondencias aluden a la existencia de un espacio de navegación común en el que la seguridad dependía de las referencias visuales que se pudiesen encontrar en la costa. Por tanto, las idas y venidas entre estos lugares con ocasión de la celebración de ciertos cultos podrían poner de manifiesto una frecuentación común de los santuarios, así como de sus fiestas, situados en puntos destacados del litoral ${ }^{26}$.

En época clásica las Cibernesias eran probablemente administradas por el genos de los phoinikes ${ }^{27}$. Dionisio de Halicarnaso (Din. I0.312, ${ }_{4} \mathrm{R}$ ) alude a un enfrentamiento entre los falereos $(\Phi а \lambda \eta \rho \in ́ \omega v)$ y los fenicios (Фоі́vıкаs) por el sacerdocio de Posidón, divinidad que, como veíamos, aparece recibiendo las ofrendas de los fieles en el decreto de los salaminios y en el calendario de Tórico. El término, como otros mencionados por las fuentes, aludiría a una presencia fenicia, o de origen fenicio, en suelo griego

\footnotetext{
22 Sobre estas divinidades -Leucotea, Leucosia- y las «Rocas blancas» que orientaban a los navegantes y se identificaban con una actuación divina benévola: G. Nenci, «Leucopetrai Tarentinorum (Cic., Att., 16, 6, I) e l'itinerario di un progettato viaggio ciceroniano en Grecia», $A S N P$, s. III, 3.2, 1973, 387-396; «ФО $\Phi \Omega P O \Sigma$ AKTH», ASNP, s. III, 5.2, 1975, 99-Ior; M. Giangiulio, «Appunti di storia dei culti», en: Neapolis. Atti del XXV Convegno di Studi sulla Magna Grecia, Taranto 1985, Tarento, 1988, I29 ss.; «Tra mare e terra. L'orizzonte religioso del paesaggio costiero», en: La Magna Grecia e il mare. Studi di storia maritima, Prontera, F. (Ed.), Tarento, 1996, 260 ss.

23 Hdt. 8.94.2; Str. 9.1.9; Plu. Sol. 9.6.7; mor. 87Id; cf. N. Robertson, «Athena and early Greek society: Palladium shrines and promontory shrines», en M. Dillon (Ed.), Religion in the Ancient World. New themes and approaches, Amsterdam, 1996, 450-451.

24 Paus. I.3.I; 44.8. Este enfrentamiento aparece también representado en algunas cerámicas como en la copa de Aison que se conserva en el Museo Arqueológico Nacional, donde encontramos en el medallón central a Atenea contemplando el triunfo de Teseo sobre el Minotauro (s. V a.C.): R. Olmos, «Introducción a la copa de Aison», en Olmos (coord..), Coloquio sobre Teseo y la copa de Aison, 28-29, 33-35.

25 Sobre las funcionas de Atenea bajo este apelativo: C. Anti, «Athena marina e alata», MonAL, 26, 1920, col. 278 ss.

26 Polignac, «Divinités regionales...», 32.

27 Ferguson, «The Salaminioi of Heptaphylai...», 27.
} 
durante la época arcaica y clásica, lo que ha suscitado no pocas polémicas ${ }^{28}$. A mi modo de ver, no creo que sea extraño encontrar la huella fenicia en algunos ámbitos de la cultura griega como, por ejemplo, la religión y más aún en relación con cultos asociados a la navegación. Los fenicios habían establecido contactos comerciales con el mundo griego desde una época muy antigua como claramente ponen de manifiesto los textos homéricos donde, asociados a un tipo de actividad comercial ajena a los métodos de intercambio ejercidos por la aristocracia, son calificados como "rapaces" (Od. 15.415), "ladinos" (Od. 15.459), "falaces e intrigantes" (Od. 14.288), "mentirosos" (Od. 14.295) y "portadores de mil baratijas" (Od. 15.416) ${ }^{29}$. Por su parte, Heródoto atribuye a los fenicios, además de avances tan importantes como la introducción del alfabeto (5.58), la fundación de algunos santuarios precisamente orientados hacia el ámbito marino, como el de Afrodita en Citera (I.IO5.3) ${ }^{30}$ y el de Heracles en Tasos (2.44.4-5; cf. Paus. 5.25.I2). Del mismo modo, la arqueología ha corroborado la presencia de comerciantes griegos en ciudades fenicias y, en general, en la zona levantina ${ }^{31}$, así como la comunión de intereses griegos y fenicios en su expansión hacia occidente, bien reflejados en algunas colonias como Pitecusa ${ }^{32}$.

El santuario de Afrodita en Citera estaba situado en una montaña y también se vincula con una fundación fenicia en la obra de Pausanias, el cual nos dice, al hablar del

28 Sin duda es de nuevo Bernal quien ha defendido con mayor intensidad la herencia fenicia de la cultura griega: Atenea negra..., 99 ss., 311 ss.

29 Cf. D. Musti, «Modi e fasi della rappresentazione dei Fenici nelle fonti letterarie greche», Atti del II Congresso Internazionale di Studi Fenici e Punici, I, Roma, 1991, I6I-I68; I.J. Winter, «Homer's Phoenicians: History, Ethnography, or Literary Trope? [A Perspective on Early Orientalism]», The Ages of Homer. A Tribute to Emily Townsend Vermeule, Austin, 1995, 247-27I.

30 Según otra versión (D.H. I.50.I) el santuario habría sido fundado por Eneas después de huir de Troya. 3I J.N. Coldstream, P.M. Bikai, «Early Greek Pottery at Tyre and Cyprus: Some preliminary comparisons», $R D A C$, 1988, 35-44; P.J. Riis, «Les problèmes actuels de l'établissement pré-hellénistique de Grecs sur la côte phénicienne (lieux, dates, modalités)», Atti del II Congresso Internazionale di Studi Fenici e Punici, I, 203-2II; J.C. Waldbaum, «Early Greek contacts with the southern Levant, c. Iooo600 B.C. The Eastern perspective», BASOR, 293, 1994, 53-66; R.A. Kearsley, «Greeks Overseas in the $8^{\text {th }}$ century B.C.: Euboeans, Al Mina and Assyrian Imperialism», en G.R. Tsetskhladze (ed.), Ancient Greeks West and East, Leiden, 1999, I09-134; Domínguez Monedero, «La Religión en el emporion», 23 I ss.; J. Boardman, «Greeks in Syria: Pots and People», en G.R. Tsetskhladze, A.M. Snodgrass (eds.), Greek Settlements in the Eastern Mediterranean and the Black Sea, Oxford, 2002, I-16; J. Luque, Ports of Trade. Al Mina and Geometric Greek Pottery in the Levant, Oxford, 2003.

32 D. Ridgway, «Phoenicians and Greeks in the West: a view from Phitekoussai», en G.R. Tsetskhladze, F. de Angelis (eds.), The Archaeology of Greek Colonisation. Essays dedicated to Sir John Boardman, Oxford, 1994, 35-46; Domínguez Monedero, «La Religión en el emporion», 234 ss. 
templo de Afrodita Urania en el ágora de Atenas ${ }^{33}$, que los primeros que veneraron a Urania fueron los asirios, y posteriormente los de Pafos, los fenicios de Ascalón y los de Citera que lo aprendieron de estos últimos. Se conserva además un decreto, datable en el 333, que permitía a los comerciantes de Kition construir un hieron dedicado a Afrodita Urania en el $\mathrm{Pireo}^{34}$. Asimismo, una inscripción confirma la existencia de un thiaso de Afrodita en el Pireo, lo que sin duda debe vincularse con la diosa de los comerciantes de Kition ${ }^{35}$. La relación de Afrodita con la navegación y con Citera aparece ya en los textos homéricos, donde se la denomina KuӨ́éfєa (Od. 8.288; 18.193) $)^{36}$. Sin duda, uno de los mayores estimulantes del culto de Afrodita en la isla debió de ser la frecuente llegada de barcos a sus costas ya desde mediados del III milenio a.C. ${ }^{37}$. Los restos arqueológicos del templo de Afrodita Urania no van más allá del siglo VI a.C., aunque es muy posible que un estudio sistemático ofreciese una fecha anterior ${ }^{38}$. Desde luego, todos los datos indican que el culto de esta divinidad en Citera es muy antiguo.

En cuanto al templo de Heracles en Tasos, existen ciertas reticencias a admitir el origen fenicio subrayado por Heródoto por lo que la mayor parte de los autores prefiere remontar la antigüedad del culto a la llegada de los colonos parios hacia el primer cuarto del siglo VII a.C. ${ }^{39}$. Según una estela hallada en el puerto que data de la primera mitad

33 Cf. T.L. Shear Jr., «The Athenian Agora: Excavations of 1980-1982», Hesperia, 53, 1984, 24-40; V. Pirenne-Delforge, «Épithètes cultuelles et interprétation philosophique. À propos d'Aphrodite Ourania et Pandémos à Athènes», $A C, 57,1988$, 142-157; L'Aphrodite grecque. Contribution à l'étude de ses cultes et de sa personnalité dans le panthéon archä̈que et classique, Atenas-Lieja, 1994, I5 ss. También se daba el culto de Afrodita Urania cerca de los Jardines (Paus. I.19.2).

$34 I G \mathrm{II}^{2} 337$. Cf. J. Pouilloux, «Étrangers à Kition et Kitiens à l'étranger», $R D A C$, I988 II, 96.

$35 I G \mathrm{II}^{2}$ I26I; P. Foucart, «Décrets d'un thiase d'Aphrodite», $B C H, 3$, I879, $510-515$.

36 También es Citerea en el Himno homérico a Afrodita (5.6, 175, 287; 6.18; 10.I) y en la Teogonía de Hesíodo (19i-20I). Cf. D.S. 5.77.5.

37 J. Yakar, «Cythera and the Ancient East», Anatolica, 4, 1971-1972, 135 (analiza la presencia de exvotos que muestran la llegada de navegantes egipcios y cananeos). También había en la isla un santuario dedicado a Apolo (Th. 7.26).

38 H. Plommer, «Kythera: the doric fragments preserved in Ayios Kosmas», en J.N. Coldstream, G.L. Huxley, (Eds.), Kythera. Excavations and Studies conducted by the University of Pennsylvania Museum and the British School at Athens, Londres, 1972, 311-313.

39 M. Launey, Le sanctuaire et le culte d'Héraklès à Thasos, Études Thasiennes I, París, 1944, I30 ss.; J. Pouilloux, Recherches sur l'histoire et les cultes de Thasos I, Études Thasiennes 3, París, 1954, 27 ss.; B. Bergquist, Herakles on Thasos. The Archaeological, Literary and Epigraphic Evidence for his Sanctuary, Status and Cult Reconsidered, Uppsala, 1973: 32-39; J. des Courtils, A. Pariente, «Excavation in the Heracles Sanctuary at Thasos», en R. Hägg, N. Marinatos, G.C. Nordquist (Eds.), Early Greek Cult Practice. Proceedings of the Fifth International Symposium at the Swedish Institute at Athens, Ig86, Estocolmo, 1988, I2I-I23; «Problèmes topographiques et religieux à l'Héracléion de Thasos», en 
del siglo V a.C., hubo una vía que unía el templo de Heracles con el puerto por la que transcurrían las procesiones ${ }^{40}$. La inscripción indica que había toda una serie de prohibiciones que afectaban al estado de esta vía sacra durante las ceremonias, por lo que es posible deducir que el santuario de Heracles se integró en las celebraciones asociadas al puerto. Una de las disposiciones establece que las mujeres no pueden asomarse a las ventanas mientras está pasando la comitiva, lo cual se ha relacionado, por una parte, con la exclusión de las mujeres en el culto de Heracles Tasio -que se conoce gracias a un reglamento relativo al culto del dios que se data hacia la segunda mitad del siglo $\mathrm{VI}^{41}$-, y por otra, con las figurillas y representaciones de mujeres en las ventanas que, en general, se asocian a la prostitución sagrada ${ }^{42}$. Esta práctica se vincula en Oriente a Ishtar-Astarté ${ }^{43}$ y también en Chipre, donde la divinidad se identificó con Afrodita ${ }^{44}$.

Pero volviendo a la interpretación de phoinikes como un genos de fenicios, me gustaría recordar que la epigrafía ha confirmado la existencia de este tipo de términos en otros lugares del mundo griego. Tenemos constatada, por ejemplo, la existencia de un mes Фоциккаîos en Corinto, Corcira, Butroto, Dodona, Ambracia y Caradros ${ }^{45}$. De etimología discutida, una parte considerable de la investigación ha optado por relacionar el término con una alusión a la púrpura y al color rojo y no con los fenicios. Sin embargo, creo que, además de que el vínculo entre la púrpura y los fenicios es evidente por la comercialización que éstos hicieron del múrice, en algunos de los lugares que

R. Étienne, M.Th. Le Dinahet (Eds.), L’espace sacrificiel dans las civilisations méditerranéennes de l'antiquité, Lyon, 1991, 67-73.

40 H. Duchêne, La stèle du port. Fouilles du port I. Recherches sur une nouvelle inscription thasienne, Études Thasiennes 14, París, 1992, esp. 4I ss.

4I Duchêne, La stèle du port..., cat. n. 23 y pp. 52-54. En contra de la lectura de Duchêne, pero interpre-

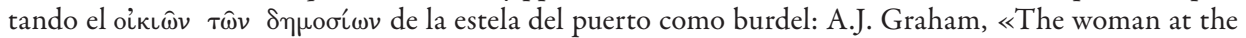
window: observations on the "stele from the harbour" of Thasos», JHS, i18,1998, 22-40.

42 W. Fauth, Aphrodite Parakyptusa. Untersuchungen zum Erscheinungsbild der vorderasiatischen Dea Prospiciens, Wiesbaden, 1967; «Sakrale Prostitution im vorderen Orient und im Mittelmeerraum», JbAC, 31, 1988, 24-39; W. Helck, reseña al libro de W. Fauth, Aphrodite Parakyptuse, en: Gnomon, 40.2, 1968, 217-220; K. Schauenburg, «Frauen im Fenster», $M D A I(R)$, 79, 1972, I-15.

43 J. Karageorghis, «Chypre et Aphrodite», Chypre, Les Dossiers d'Archéologie, 205, 1995, 80-83; A. Aloni, «Osservazioni sul rapporto tra schiavitù, commercio e prostituzione sacra nel mondo arcaico», Index, II, 1982, 259-261; A.J. Domínguez Monedero, «Las esclavas sagradas de Afrodita», ARYS, 4, 200I, III-I 40.

44 S. Dow, «Corinthiaca. I. The month Phoinikaios», AJA, 46, 1942, 69-72; P. Cabanes, «Recherches sur le calendrier corinthien en Épire et dans les régions voisines», $R E A$, I05, 2003, 86-88, 93-94.

45 M.A.V. Gill, «Some observations of marine animals in Minoan art, and their identification», en: L'iconographie Minoenne, supp. XI BCH, París, 1985, 77-81. Cf. sobre este tipo de ofrenda: Romero Recio, Cultos maritimos..., 70 ss. 
hemos mencionado existen otros lazos con el ámbito fenicio y a su vez con una religiosidad asociada al mar que veremos a continuación.

La aparición de conchas se asocia, ya desde época minoica, con la Diosa del Mar y con el deseo de asegurar una continuidad de las actividades relacionadas con este medio ${ }^{46}$. Se constata la ofrenda de múrice en el santuario de Afrodita en Cnido (Plin. nat. 9.80; cf. 32.5-6), lo cual puede relacionarse con el epíteto de «purpúrea» que le otorga Anacreonte (Page, $P M G, 357.3$ ). Según Plinio (nat. 9.80) las conchas que había en el santuario de Cnido tenían la facultad de inmovilizar los barcos, como mostraron al frenar la nave de Periandro que conducía a unos jóvenes nobles para ser castrados ${ }^{47}$. La existencia de un templo dedicado a Afrodita Euplea en Cnido aparece mencionada en varias fuentes y ha sido localizado por la arqueología. Se trata de un edificio redondo con dieciocho columnas dóricas ubicado en la parte más alta de la ciudad dominando los puertos ${ }^{48}$. El epíteto que lleva la diosa pone claramente de manifiesto que la Afrodita de Cnido era venerada por su faceta de protectora de los navegantes. Aunque el templo data del siglo IV, los restos arqueológicos demuestran que en esta área existía ya un culto desde época arcaica, si bien parece que el epíteto Euplea no puede remontarse más allá del siglo VI. De hecho, Pausanias (I.I.3) señala que los cnidios veneraban especialmente a Afrodita y que tenían santuarios dedicados a esta divinidad: el más antiguo el de Afrodita Dorítide, después el de Afrodita Acrea y el más reciente el de Afrodita Cnidia o Euplea ${ }^{49}$. Volveré a mencionar en numerosas ocasiones a Afrodita como divinidad protectora en el mar.

Por otra parte, en Casíope (Corcira) y en Butroto tenemos confirmada la existencia de un culto a Zeus Casio. En el templo de Casíope, de datación tardía -s. I a.C.se veneraba a este dios como deidad de los navegantes. Las representaciones de barcos en las monedas corcirenses y en algunas cerámicas parecen aludir al desarrollo de la navegación en la isla, así como a la celebración de regatas en honor de Posidón, Dioniso

46 Cf. Hdt. 3.48; Plu. De Herod. malign. 22. También al múrice se asocia Afrodita en su santuario de Citera, mencionado más arriba.

47 Cf. Plin. nat. 36.4.21; Luciano, Am. In ss.; Psd. Luc. Erot. II-I2. I.C. Love, «A Preliminary Report of the Excavations at Knidos 1969», AJA, 74, 1970, 154 ss.; «A Preliminary Report of the Excavations at Knidos 1970», $A J A, 76,1972,70$ ss.; «A Preliminary Report of the Excavations at Knidos 1970», AJA, 76, 1972, 393-405; «A Preliminary Report of the Excavations at Knidos 1972», AJA, 77, 1973, 419-424. 48 Sobre estas advocaciones de Afrodita y su relación con el mar: M. Romero Recio, «Inscripción a Zeus Casio y Afrodita sobre ancla de plomo hallada en 1905», Ostraka. Rivista di antichità, 8.2, 1999, 541-549; Cultos maritimos..., 82, I19-I20. Como veremos más adelante, también Isis llevó el epíteto Euplea.

49 Sobre estas advocaciones de Afrodita y su relación con el mar: M. Romero Recio, «Inscripción a Zeus Casio y Afrodita sobre ancla de plomo hallada en I905», Ostraka. Rivista di antichità, 8.2, 1999, 54I 549; Cultos marítimos..., 82, II9 I20. Como veremos más adelante, también Isis llevó el epíteto Euplea. 
y Apoloso. Procopio, en el siglo VI d.C., cuenta que cerca de la ciudad de Casíope había una nave construida en piedra que tenía una inscripción realizada por un comerciante como dedicatoria a Zeus Casio ${ }^{51}$. En Butroto, ciudad del Epiro que está frente a Casíope, apareció un cipo votivo datado entre los siglos II-I a.C. en el que el dedicante había consagrado a Zeus Casio la imagen de un navío como exvoto de agradecimiento por una feliz navegación, y prometía ofrecer uno de oro si el dios le concedía riqueza ${ }^{52}$. Los fenicios asimilaron a Zeus Casio con Baal Safón, el dios que protege a los navegantes y que, como Zeus, tiene poderes para provocar o evitar un naufragio, pues ambos regulan los fenómenos atmosféricos que inciden directamente en las condiciones de navegación ${ }^{53}$. Además, en general, los dioses honrados por los fenicios de Grecia bajo el nombre de Zeus eran divinidades marinas ${ }^{54}$.

Tenemos a su vez otra conexión interesante entre el color rojo, la púrpura y un término relacionado con el ámbito fenicio que nos acerca a su vez a Atenas. En Corinto, además de un mes Phoinikaios había un culto de Atenea donde la diosa, que tenía un templo (Lyc. Alex. 5.658) llevaba el epíteto Фоьvíкๆ. En general, se ha considerado que la epíclesis hace referencia a que la estatua de Atenea estaba pintada de rojoss, cosa que, bajo mi punto de vista, además de no excluir su conexión con el ámbito fenicio, puede reforzar su carácter marino. Atenea es una divinidad que sin ser propiamente marina, se adaptó sin dificultad al mundo de la navegación porque era la protectora de la téchne y, por tanto, de la construcción naval. Además de fabricar los barcos, los guiaba acompañando a los pilotos -entre ellos Odiseo- que se convirtieron en sus principales prote-

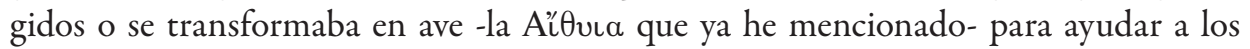
marineros. Su actividad en el mar se potenció mediante la ofrenda de objetos alusivos, como timones o espolones, y la fundación de santuarios en promontorios donde la

so P. Gardner, «Boat-Races among the Greeks», JHS, 2, 1881, 90-97; B.V. Head, Historia numorum. A manual of Greek Numismatics, Oxford, I911, 327.

5I De bell. goth. 4.22, p. 576, Dind. II.

52 A. De Franciscis, «Iscrizioni di Butrinto», RAAN, 21, 1941, 276-278, fig. I (la sitúa cronológicamente en el s. I); L. Robert, 1944, irga (la data en el siglo II).

53 Sobre Zeus Casio y Baal Safón como deidades de los navegantes: Romero Recio, «Inscripción a Zeus Casio...», 54I-549; «Economía de la colonización fenicia: Empresa estatal vs. Empresa privada», Economia y Finanzas en el mundo fenicio-púnico de Occidente. XX Jornadas de Arqueología Feniciopúnica, Ibiza, 2006, 9-26.

54 M.F. Baslez, «Cultes et dévotions des phéniciens en Grèce: les divinités marines», Studia Phoenicia, 4, Namur, 1986, 298.

55 O. Masson, J.L. Perpillou, J. Taillardt en M. Lejeune (dir.), Dictionnaire étymologique, IV.2, s.v. фoîvı, pp. 1217-I218; J. Schmidt, RE, 20, 194I, 349, 21 ss.; A. Wilhelm, Attische Urkunden, Viena, 1942, II, 23-30. 
diosa también llevó epítetos característicos (Promacorma, Etía o Ekbasia) ${ }^{56}$. Pero, como decía, Atenea tiene un vínculo interesante con el color rojo y con el mar. En el Lapidario Órfico (568-572) aparece mencionada una leyenda según la cual, el color del coral tendría su origen en la sangre de la Gorgona -cuya cabeza ocupaba el centro de la Égida de Atenea- que habría llegado al mar cuando Perseo se lavó en sus aguas. Menciona además que Atenea proporcionó al coral la propiedad de proteger a quien debía emprender un viaje por mar durante la navegación y contra los ataques de los piratas (Lap. Orph. 522-523, 578-585). Su asociación con la Gorgona deriva de la creencia en su poder para petrificar ${ }^{57}$. El Lapidario náutico ${ }^{58} \mathrm{y}$ los kérigmas lapidarios órficos (20) dicen que el coral colocado en lo alto del mástil junto con una piel de foca protege de los vientos, las olas y demás contratiempos evitando el naufragio. Por su parte, Plutarco (mor. 664 c) señala que la pieles de las focas y las hienas mantenían alejados los rayos del mástil de la nave. El coral aparece con cualidades semejantes a las mencionadas también en la Historia Natural de Plinio (36.164) -resiste los rayos y los tifones-, en el Lapidario Latino -en el barco rechaza los vientos, las tempestades y los tifones ${ }^{59}$ - y en Isidoro cuando dice que puede resistir las tempestades y el granizo (Etim., I5.25).

Encontramos también el color rojo en relación con la protección de los navegantes en las iniciaciones de los Grandes Dioses de Samotracia. Según Apolonio de Rodas (I.915-92I), Jasón y sus compañeros, siguiendo los mandatos de Orfeo, se iniciaron en los misterios de estas divinidades antes de seguir su camino para «poder así surcar sanos y salvos la heladora superficie del mar». El escoliasta de este autor (en I.917b), indica que Odiseo fue igualmente iniciado en Samotracia llevando puesto alrededor de su cuerpo el velo que Ino-Leucotea le había dado para salvarse del naufragio ${ }^{60}$, y por

56 Sobre Atenea como diosa protectora de los navegantes: Romero Recio, Cultos marítimos ..., especialmente, 3 ss., 25 ss., 36 ss., 93 ss., II3 ss., 130 ss., I 4I ss. R. Parker insiste en que Atenea no es una diosa asociada a la navegación, pues lo único que puede vincularla a esta actividad es su protección sobre los artesanos y el hecho de ser invocada como Salvadora: Parker, Athenian Religión..., 240, n. 81; Polytheism and Society at Athens, Oxford, 2005, 410.

57 El coral es la Gorgona: Plin., nat., 37.164; Kérigmas lapidarios órficos, 20. Aparece también asociado a la Gorgona en la glíptica mágica: S. Perea, «Magic at sea: amulets for navigation», en R. Gordon, F. Marco (eds.), Magical Practice in the Latin West: Papers from the International Conference Held at the University of Zaragoza, $30^{\text {th }}$ Sept. - $I^{\text {st }}$ Oct. 2005, Leiden, 2009, 457-486.

58 En R. Halleux, J. Schamp, Les lapidaires grecs, París, 1985, I8I-189. La relación de las piedras mencionadas en el Lapidario náutico con la magia en el mar han sido analizadas por S. Perea en: «Magic at sea...», 457-486.

59 Damigéron-Évax 7.3 (en Halleux, Schamp, Les lapidaires grecs).

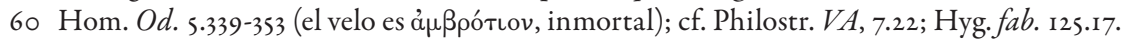


esta razón los que se iniciaban en estos misterios rodeaban sus cuerpos con cintas de color púrpura para escapar a los peligros de la navegación ${ }^{61}$.

Así pues, no creo que sea descabellado plantear que una diosa con la advocación Phoinike y pintada de rojo como la de Corinto pueda tener una relación con el mundo marino, sobre todo teniendo en cuenta que se trata de una ciudad con dos puertos que disponía de otros muchos cultos y fiestas relacionados con la navegación ${ }^{62}$. Pero es que además, el mes Phoinikaios corintio se corresponde con el Targelión ateniense (mayo-junio) ${ }^{63}$, mes que marca el comienzo del verano y en el que, como veremos en el siguiente apartado, se celebraban las Plinterias en honor de Atenea -unas fiestas que creo que pueden vincularse al mar y la navegación- y en el que tenía lugar en Tórico el sacrificio de una oveja en honor de un héroe llamado Sosineo cuyo nombre debe relacionarse con la salvación en el mar ( $\sigma \omega \zeta^{\prime} \omega$ vavŝ) y que, además, figura como epíteto de Posidón en Panticapeo ${ }^{64}$. Recordemos, asimismo, que en Falero había un santuario dedicado a Atenea Escírada a donde llegaba la procesión de las Oscoforias.

Robertson no cree que las Cibernesias sean una festividad independiente, sino que se trataría de unos ritos que se enmarcaban precisamente en la fiesta que mencionaba en último lugar, las Oscoforias ${ }^{65}$. Esta festividad se celebraba en el mes de Pianopsión (octubre/noviembre), aunque no está claro en qué día, entre el 6 y el 8. El acto principal consistía en una procesión que iba desde el templo de Dioniso en Atenas al de Atenea Escírada en Falero ${ }^{66}$. El día 8 se conmemoraba el regreso de Teseo desde Creta y se celebraban las Theseia ${ }^{67}$, aunque también se decía que el héroe había llegado

6I Véase M. Detienne, «Le navire d'Athéna», RHR, 178, 1970, I4I; M. Detienne, J.P. Vernant, Las artimañas de la inteligencia. La metis en la Grecia antigua, Madrid, 1988, 194. Sobre la devoción de los marineros a los Grandes Dioses de Samotracia constatada en un considerable número de dedicatorias:

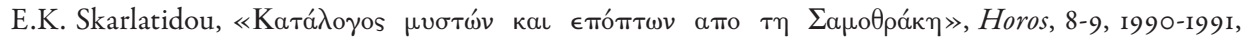
153-172; S.G. Cole, Theoi Megaloi: the cult of the Great Gods at Samothrace, EPRO 96, Leiden, 1984, 61 ss.; Romero Recio, Cultos maritimos..., 4, 83, 92-93; N.M. Dimitriova, Theoroi and Initiates in Samothrace. The Epigrphical Evidence, Princeton, 2008.

62 Por ejemplo, en la descripción que Pausanias (2.1.7-9) realiza del famoso templo de Posidón en Corinto destaca la decoración basada en personajes y elementos marinos.

63 Cabanes, «Recherches sur le calendrier corinthien...», 94.

64 L. 50; cf. Kearns, The Heroes of Attica, 37; Lupu, Greek Sacred Law..., I21-122, I 45.

65 N. Robertson, Festival and legends: The formation of Greek cities in the light of public festivals, Toronto 1992, I20 ss.; «Athena and early Greek society...», 446-447.

66 Véase el apartado II.4.

67 E. HF. 1328-1331; Ar. Pl. 627-628; Plu. Thes. 36.4-5. Se instituyó como festival ateniense estatal en el 475 a.C. Cf. H.W. Parke, Festivals of the Athenians, Londres, 1977, 81; J.D. Mikalson, The sacred and civil calendar of the Athenian Year, Princeton, 1975, 70; Religion in Hellenistic Athens, Berkeley, 1998, 252-253; Parker, Polytheism and Society..., 483-484. 
el día 7, cuando tenían lugar las Pianopsias ${ }^{68}$. El día 6 de Muniquión (abril/mayo), antes de zarpar, el héroe había acudido al Delfinio, y el día 7 de Pianopsión, cuando regresó, volvió a presentar a Apolo Delfinio la rama de olivo de la $\epsilon i \rho \in \sigma \iota \omega ́ v \eta$, ofrenda que se renovaba durante las Pianopsias ${ }^{69}$. Como veremos un poco más adelante, el $6 \mathrm{de}$ Muniquión las doncellas realizaban una procesión hasta el Delfinio ligada etiológicamente a la saga de Teseo (Plu. Thes. 18. 2; Poll. 8.119) que se ha puesto en relación con el culto de Ártemis Delfinia.

El viaje de Teseo es, por tanto, elocuente -como veremos más detenidamente en el siguiente apartado- cuando lo relacionamos con la estación navegable: parte en su nave el 6 del mes de Muniquión (abril/mayo) -aproximadamente cuando se abre la temporada naviera ${ }^{70}$ y cuando todavía en la actualidad se siguen celebrando fiestas asociadas al mar como la de San Telmo ${ }^{71}$ - (Plu. Thes. I8.2) y regresa, según Plutarco (Thes. 36.5), el 8 de Pianopsión (octubre/noviembre) -cuando se cierra-. El autor indica asimismo, que, en general, se tributan honores a Teseo los restantes días ocho, bien porque cuando llegó de Trecén era el 8 de Hecatombeón (julio/agosto), o bien porque a Posidón, según algunas tradiciones el padre de Teseo, se le rendía culto los días ocho. Además el ocho, representaba, también según Plutarco, la solidez y firmeza que caracterizaban a Posidón, al que llamaban Asfalio y Géoco («Abarcador de la tierra»). Resulta significativo que precisamente se le recuerde con el epíteto de Asfalio, una de las advocaciones que el dios del mar presenta en algunos santuarios costeros de importancia ${ }^{72}$.

68 Véase el apartado II.4.

69 Plu. Thes. 18, 22; Parke, Festivals of the Athenians..., 75 ss.; Calame, Thésée et l'imaginaire athénien..., 291 ss.

70 Existen dos concepciones de la estación navegable, una corta, del 27 de mayo al 14 de septiembre (Hes. Op. 665-669), y una larga, desde principios de marzo al in de noviembre (Dem. Con. Apat. 23)-, un calendario que llegará hasta época romana. Cf. Veg. mil. 4.39; 5.9; Macr. sat. I.I2.14; Symm. ep. 4, 58 y 63 ; Chrysost. hom. 9, PG, 49, 107; hom. 25, PG 59, 152; Hier. epist. 108, CSEL, 55, 312; Marc. Diac. V. Porph. 33.4, PL 65, I227; Cod. Theod. 13.9.3. J. Rougé, «La navigation hivernale sous l'Empire Romain», REA, 54, 1952, 318; L. Casson, Ships and Seamanship in the Ancient World, Baltimore-Londres, 1995 (I ${ }^{\mathrm{a}}$ ed. 197I), 270; J. Alvar, «Los medios de navegación de los colonizadores griegos», $A E A$, 52, 1979, 67-83.

7I Entre marzo y abril, 8 días después del domingo de Pascua, tiene lugar la fiesta dedicada a este Santo patrón de los marineros.

72 Por ejemplo, el del Ténaro: Th. I.I28.I, I33; Ar. Ach. 509-511; schol. Ar. Ach. 509-511; Paus. 4.24.5 ss.; Ael. $V H$. 6.7. W. Cummer, «The sanctuary of Poseidon at Tainaron, Lakonia», $\operatorname{MDAI}(A), 93,1978$, 35-43; J. Ducat, «Esclaves au Ténare», en: Mélanges Pierre Lévêque, 4, Religion, París, 1990, 173-193; R.W.M. Schumacher, «Three related sanctuaries of Poseidon: Geraistos, Kalaureia and Tainaron», en N. Marinatos, R. Hägg (Eds.), Greek Sanctuaries: New Approaches, Londres, 1993, 72-76. 
El mito de Teseo está vinculado al mar y no sólo por lo que respecta a su aventura cretense. Como hijo de Posidón, desciende al fondo del océano a lomos de los delfines donde Anfítrite le otorga los símbolos reales que legitiman la posición del héroe: un anillo (que según Baquílides no recupera), una túnica púrpura y una corona ${ }^{73}$. La constatación de que Teseo es considerado como un héroe que interviene en la actividad náutica encuentra además confirmación en los sacrificios que se le ofrecen conmemorando el éxito obtenido en las batallas navales durante la guerra del Peloponeso (Paus. IO.II.6).

No creo, como supone Robertson, que las Cibernesias sean un ritual más de las Oscoforias pues contamos con datos suficientes para sostener la independencia de esta fiesta que, junto con otras, gira en torno a los mismos personajes. En mi opinión, estas festividades reflejan, por una parte, el deseo ateniense de «nacionalizar» la figura de Teseo así como de integrar los cultos salaminios y, por otra, la importancia de las tradiciones míticas asociadas al mar que los participantes en estas celebraciones debían conocer y asimilar. La sucesión de fiestas que de una manera u otra se vinculan a los viajes marítimos de los héroes, así como a las divinidades de los navegantes, no pueden interpretarse de espaldas al mar.

Teniendo en cuenta los datos expuestos, creo que efectivamente la celebración del sacrificio en honor de Posidón Hippodromios, Feacio, Teucro y Nauseiro formaba parte de las Cibernesias, pues se está honrando al dios del mar y a los dos héroes navegantes, cuyos nombres aluden sin duda a los marineros profesionales de la Odisea, los feacios, y a su rey, Nausítoo, hijo del propio Posidón y de Peribea (Od. 5.35 ss.; 6-8; 13.12 ss.). Como indicaba más arriba, es probable incluso que el nombre originario del piloto de Teseo hubiese sido Nauseiro, para pasar a ser llamado posteriormente Nausítoo con el fin de aproximarlo aún más a la onomástica de los navegantes míticos. El santuario de Posidón en Falero no ha sido localizado, pero sabemos que en el siglo IV los fenicios de Falero asumieron un sacerdocio local de Posidón (D.H. Din. I0.312, 4 R).

73 Cf. B. 12, 17-18 Snell-Maehler, Hyg. astr. 2.5.3. Cf. Calame, Thésée et l'imaginaire athénien..., 232 ss.; A. Bernabé, «El mito de Teseo en la poesía arcaica y clásica», en Olmos (coord.), Coloquio sobre Teseo y la copa de Aison, ir2. El encuentro entre Teseo y Anfítrite en el fondo del mar aparece representado, por ejemplo, en la copa firmada por Eufronios y atribuida a Onésimos del Museo del Louvre (G IO4; Badd. 2, p. 214; AA.VV., Euphronios, peintre à Athènes, París, 1990, nº 55) y tal vez en una estela del s. V aparecida en Italia: L. Cerchiai, «La rappresentazione di Teseo sulle stele Felsinee», en F.H. Massa-Pairault (ed.), Le mythe grec dans liItalie antique. Fonction et image, Roma 1999, 353-365 (da otra interpretación de esta misma estela: G. Sassatelli, «Rappresentazioni di giochi atletici in monumenti funerari di area padana», en Spectacles sportifs et scénique dans le monde étrusco-italique, Atti del Convegno Roma 1991, Roma I993, 60-62). 
R. Parker opina que el epíteto Hippodromos podría relacionarse con el hipódromo de Equelidas en la región de Falero y apunta a que tal vez a la celebración de las Cibernesias se asociase una carrera de caballos ${ }^{74}$. La vinculación de Posidón con el caballo y el carro $^{75}$, así como la proximidad entre la terminología náutica e hípica es bien conocida ${ }^{76}$. La aparición de cerámicas en forma de nave con cabeza y prótomos de caballos se remonta a una época muy antigua en Chipre ${ }^{77}$ y estudios del vocabulario parecen confirmar que los términos que se utilizan para aludir a la inteligencia que el carpintero necesita para construir un carro y un navío son los mismos que cuando se alude a la inteligencia que debe ponerse en marcha para guiar una nave y conducir un carro $^{78}$.

Por su parte, Baslez, opina que podría haber existido previamente un santuario dedicado a Posidón en Falero, vinculado al genos de los Hipotoontidas, llamados así por su epónimo, el héroe ático Hipotoonte, hijo de Posidón (cf. Harp. s.v. 'A $\lambda$ ó Posteriormente, los fenicios asentados en la zona habrían asimilado a esta divinidad con una propia y se les habría concedido el sacerdocio del santuario ${ }^{79}$. Independientemente de que se acepte la vinculación de este dios con el genos de los Hipotoontidas, está constatada la existencia de otros sacerdotes fenicios de Posidón en ámbito griego, por lo que no veo razón para negar esta vinculación ni en Falero ni en los restantes lugares a los que hemos aludido ${ }^{80}$. Según Diodoro (5.58.2), en Yáliso (Rodas) un sacerdocio de esta divinidad, instituido por Cadmo, era hereditario en un genos de Фоívıкєs y está constatado que algunos thiasoi de marinos consagrados a Zeus Xenio eran de origen fenicio $^{81}$. Además, sabemos que los fenicios asentados en puertos griegos gozarán de concesiones en el ámbito cultual; por ejemplo, como ya he mencionado más arriba, en el 333 un decreto $\left(I G . \mathrm{II}^{2}, 337\right)$ permitió a los comerciantes de Kition construir un heroon dedicado a Afrodita Urania en el Pireo, en realidad Astarté. No encuentro, por tanto, la razón para negar la presencia de elementos fenicios en algunos cultos griegos refle-

\footnotetext{
74 Parker, Athenian Religion..., 314; Polytheism and Society..., 389, n. I0.

75 F. Schachermeyer, Poseidon und die Entstehung des griechischen Götterglaubens, Berna, 1950, 90 ss.

76 Detienne, «Le navire d'Athéna», 154.

77 M. Yon, «Duck's travels», en P. Aström (Ed.), Acta Cypria. Acts of an international congress on cypriote archaeology, Göteborg, august I99I, II, Jonsered, 1992, 398-401.

78 Detienne, «Le navire d'Athéna», I6I; A. Moreau, «L'attelage et le navire: la rencontre de deux thèmes dans l'œuvre d'Eschyle», $R P h, 53,1978,98$-II5.

79 M.F. Baslez, «Cultes et dévotions des Phéniciens en Grèce: les divinités marines», Studia Phoenicia, 4, Namur, 1986, 291.

80 Favorable a la existencia de un genos de fenicios se muestra también Parker, Athenian Religion..., 317.

8I IG $\mathrm{II}^{2}$.IOI2 (Pireo); P. Roos, «Research at Caunus», Opuscula Atheniensa 8, 1968, 160, n. I (Cauno); $I G \mathrm{XII} /$ I.I6I (Rodas); $C I L$ III.I 4932 (Beirut).
} 
jados en advocaciones, sacerdocios o nombres de meses, pues, como ya he subrayado, aunque encuentren también un significado asociado a la púrpura y el color rojo, éste no resulta ni mucho menos ajeno al ámbito fenicio. Creo que si además conectamos estos elementos fenicios con la presencia de cultos y festividades asociadas al mar, así como la importancia del comercio de la púrpura y el color rojo con algunas supersticiones también de los navegantes, podremos ofrecer una explicación más completa de algunas manifestaciones religiosas que tenemos poco documentadas.

Bajo mi punto de vista, es probable que el culto de Posidón en Falero fuese el más antiguo de los que se mencionan en el decreto de los salaminios a propósito de los sacrificios celebrados en Boedromión. La condición portual de Falero así como la existencia de cultos previos asociados a la navegación, se ofreció como el lugar óptimo para la implantación de la festividad dedicada a los héroes de los marineros, el piloto y el proreo de Teseo. Además de los cultos que ya he mencionado, como el de Atenea Escírada y Afrodita Epitragia, me gustaría recordar que Falero es el nombre de un héroe ateniense que participó en la expedición de los Argonautas ${ }^{82}$ y que, según Pausanias (I.I.4) tenía en el puerto un altar dedicado a sus hijos junto a otros de los dioses Desconocidos, de héroes y de los hijos de Teseo. Además, muy cerca de allí, se veneraba a otros héroes de los navegantes como el Sosineo de Tórico, los mencionados de Salamina o tenían lugar algunos rituales relacionados con la navegación. Me refiero a una noticia que hace referencia a un extraño ritual celebrado en el promontorio Colíade, lugar al que habían llegado los restos del naufragio de la flota aniquilada de los medos (Hdt. 8.96.2; Paus. I.I.5).

En este lugar, que se identifica con el antiguo demo de Halimunte, se veneraba una estatua de Afrodita, junto a otras de las diosas Genetílides ${ }^{83}$. Las Genetílides están relacionadas con los nacimientos y la fecundidad, y Afrodita aparece en Colíade, según algunas fuentes, también en relación con estos aspectos y con las bodas ${ }^{84}$; sin embargo, resulta interesante una consideración de Luciano (amor. 42), el cual señala en relación con las Genetílides en el cabo Colíade, que los hombres desaprobaban a las mujeres que iban a adorar a divinidades poco recomendables.

El templo de Afrodita en este promontorio no podía haber permanecido ajeno al ámbito religioso de los navegantes teniendo en cuenta, por una parte, su cercanía al puerto de Falero, y por otra, las noticias que aluden a este santuario en relación con el

82 Hes. Sc. I8I; A.R. I.96-100; Paus. I.I.4; Hyg. fab. I4.

83 Paus. I.I.5; Ar. Lys. 2 (fiesta de las Genetyllis en cabo Colíade); Nu. 49-52; schol. Ar. Lys. 2; Th. 130;

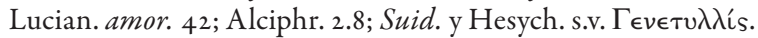

84 Schol. Ar. Nu. 51-52; Th. I30; Pirenne-Delforge, L'Aphrodite grecque..., 76. 
mar. En primer lugar, según un escolio a Aristófanes (Nu. 5I-52) la hija de un rey tirreno se había enamorado de un joven que había sido secuestrado por los piratas y lo liberó desatando las cuerdas con las que estaba retenido. En agradecimiento, el joven dedicó el santuario de Afrodita en el cabo Colíade. En segundo lugar, se decía que después de la batalla de Salamina, Lisístrato, un adivino ateniense, había vaticinado que las mujeres de Colíade «tostarían la cebada con remos» ${ }^{85}$. Sin duda alguna esta conexión entre las mujeres del promontorio y los remos hace referencia a un ritual vinculado con la navegación y puede relacionarse con las ofrendas de este aparejo, las cuales se asociaban en ocasiones al abandono de la actividad náutica ${ }^{86}$. Y en tercer lugar, algunas fuentes se refieren a la relación de la divinidad del promontorio con extranjeros y comerciantes ${ }^{87}$, por qué no -añado yo- también fenicios, lo que también explicaría la consideración de Luciano a la que aludía un poco más arriba.

Dado que en la zona se han encontrado restos que indican una ocupación muy antigua, es posible que el culto de Afrodita también lo fuera. Opino que en un principio se habría relacionado únicamente con el ámbito marítimo, incluso con connotaciones que aludiesen a la fecundidad del mar. Posteriormente, pudo haberse producido una potenciación de este último aspecto -como consecuencia también de la introducción de los cultos de las Genetílides y Deméter- de manera que, sin dejar de pertenecer al ámbito religioso de los navegantes, la diosa se vinculó de una manera más intensa al ámbito femenino. De hecho, no es inusual encontrar una disgregación de funciones plasmada en la fundación de dos santuarios diferentes como por ejemplo en Hermíone, donde había un templo de Afrodita Pontia y Limenia -claramente vinculado a la navegación-, y otro dedicado sólo a Afrodita al que acudían las mujeres antes de la boda y que no debía estar demasiado lejos del santuario de Deméter Termasia (Paus. 2.34.II-I2). Ahora bien, y puesto que no estaba bien visto que las mujeres atenienses acudiesen a este lugar, es posible que Afrodita también se relacionase en el promontorio Colíade con la prostitución, algo que se dio en Atenas y que, como ya hemos tenido ocasión de mencionar, era frecuente en los puertos, también asociada a la prostitución sagrada practicada en ámbito fenicio y próximo-oriental.

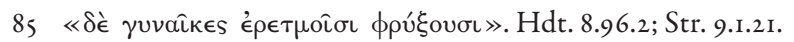

86 W.F. Hansen, «Odysseus' Last Journey», QUCC, 24, 1977, 27-48; «Odysseus and the Oar: A Folkloric Approach», en L. Edmunds (Ed.), Approaches to Greek Myth, Baltimore-Londres, 1990, 24I-272; Romero Recio, Cultos maritimos..., 22 ss.

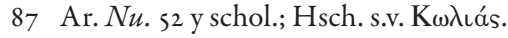


Afrodita Pandemos y Urania fue venerada en Atenas por las prostitutas ${ }^{88}$. La vinculación de esta diosa con la prostitución seguramente no corresponde a su función primitiva; probablemente se trataría de un culto instituido por Solón como medio de reforzar la vinculación a la polis del demos, pero cuya reinterpretación posterior se centraría en su epíteto (pan-demos, de todo el demos, es decir, pública) y se relacionaría con la idea de que Solón estableció burdeles en Atenas (Ath. 13.569d-e). Así pues, el espacio sacro consagrado a Afrodita Colíade podría seguir siendo frecuentado por los navegantes -que acudían a agradecer o solicitar la ayuda de la diosa, y a buscar la compañía de las prostitutas-, por estas últimas -que buscaban clientela junto al amparo de su patrona-, por las mujeres atenienses -que veneraban a la diosa como protectora de bodas y nacimientos-, e incluso por los pescadores que buscaban la fecundidad del $\operatorname{mar}^{89}$.

Domínguez Monedero también ha estudiado la relativa facilidad con la que parecen haberse implantado en lugares empóricos y portuarios los cultos vinculados con la navegación, con la defensa frente a los enemigos y con las actividades sexuales, facetas todas ellas que desempeñaba tanto Afrodita como la Astarté fenicia ${ }^{\circ}$. El autor ha destacado igualmente cómo parece haber una relación entre la prostitución y las peticiones a Afrodita por parte de las ciudades -como Corinto o Locris- en momentos de peligro, ya sean prostitutas quienes consiguen de la diosa el favor, ya sea la promesa de prostituir a quienes no lo son. Desde mi punto de vista, estas afirmaciones vienen a corroborar la simbiosis de funciones que se dan en torno a Afrodita en el cabo Colíade y en otros lugares del mundo griego. Es más, si las ciudades hacen un votum a Afrodita en momentos en los que el peligro es extremo ofreciendo un número considerable de mujeres a la diosa, creo que resulta factible plantear que tal vez los particulares, navegantes y/o comerciantes que debían enfrentarse a los avatares del mar, acudiesen a estos templos costeros o portuarios a ofrecer a Afrodita una esclava destinada a la prostitución sagrada, es decir, que la práctica de esta actividad se vinculase directamente con la petición de ayuda para superar los peligros de la navegación.

Centrándonos de nuevo en el sacrificio aparecido en el decreto del genos de los salaminios, resulta fundamental que los cultos a los miembros de la tripulación

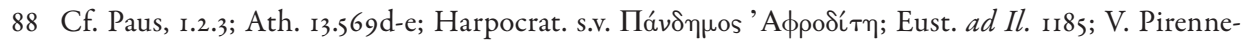
Delforge, «Aspects orientaux du culte d'Aphrodite à Athènes», Studia Phoenicia 5, Lovaina, 1987, I 45-156; «Épithètes cultuelles et interprétation...», I 42-157. Afrodita Pandemos es un buen presagio para las hetairas (Artem. Onir. 2.37).

89 Romero Recio, Cultos maritimos..., 70 ss.

90 Domínguez Monedero, «Las esclavas sagradas de Afrodita», 134 ss. 
aparezcan asociados a Posidón ${ }^{91}$. Creo que es este hecho el que definitivamente asienta las bases que permiten sostener la existencia de una festividad dedicada exclusivamente a los navegantes, y por encima de ellos, a los encargados de velar por la seguridad durante la navegación: el timonel, apostado en la popa, y el proreo vigilando la proa.

Así pues, las Cibernesias podían ser unas fiestas muy antiguas que los marineros celebraban en el puerto de Atenas asociadas, en principio a Posidón, la divinidad suprema del mar $^{92}$, que recibiría como ofrenda un sacrificio. Una vez que se introdujo la leyenda de Teseo se integraron en las celebraciones unos héroes navegantes cuya función resultaba de vital importancia durante la travesía. Probablemente el culto a los héroes salaminios se introdujo en Atenas en el siglo VI, cuando tuvo lugar la conquista de la isla ${ }^{93}$. Los marineros podían pasar así a honrar, no sólo a la divinidad que controlaba los secretos y las fuerzas ocultas del piélago, sino también a aquellos de los que dependía la seguridad de toda la tripulación, y también se integra en ese conjunto cultual a Atenea, la guía de sus viajes, que contaba con un santuario en el propio puerto. Es muy posible que los pilotos contasen con un destacable papel durante las ceremonias dado que se trataba de una festividad dedicada a sus patrones. Me parece que estas fiestas -y lo aventuro a modo de hipótesis pues no tenemos ninguna constatación arqueológica o literaria que lo corrobore- ofrecerían el marco más adecuado para la celebración de competiciones navales -y tal vez también hípicas como apunta Parkeren las que los timoneles pudieran poner a prueba sus facultades. De hecho, si como supone Calame ${ }^{94}$ la nave de Teseo se conservaba en Falero, de alguna manera también ésta podría formar parte de las celebraciones de las Cibernesias, tal vez, abriendo las regatas. Las competiciones navales aparecen en distintas festividades del mundo griego y asociadas a divinidades de los navegantes. Puesto que no era inusual que las naves de guerra de la flota compitiesen durante la navegación (Th. 6.32; X. Hell. 6.2.28; Arr. $A n$. 23.5), sería bastante razonable que estos mismos barcos participasen en regatas que se enmarcaban en unas festividades en honor de una divinidad marina, y en las cuales podían poner públicamente de manifiesto su valía. Sabemos que celebraciones de este tipo se dieron en Corcira, en Corinto, en Léucade, en Hermíone, en el Pireo, en Sunio,

9I Recordemos que después de la victoria de Salamina los atenienses dedicaron dos trirremes a Posidón, en el Istmo y en Sunio respectivamente, y otra al Gran Áyax en Salamina (Hdt. 8.I2I).

92 No creo que los datos sobre Posidón como dios del mar sean tan "fragmentarios" y "frustrantes" como opina Parker en su, por otra parte, estupendo trabajo: Polytheism and Society..., 4ro.

93 M.P. Nilsson, Cults, Myths, Oracles, and Politics in Ancient Greece, Lund, 1951, 33 ss.

94 Calame, Thésée et l'imaginaire athénien..., 148. 
en Delos ${ }^{95}$. En Sunio los atenienses celebraban unas fiestas en las que las regatas eran una parte fundamental y los naucleros extranjeros que atracaban cerca del cabo durante las fiestas estaban obligados a pagar un impuesto al templo de Posidón ${ }^{96}$. Me interesa destacar de manera especial el hecho de que se celebrasen regatas en Sunio, donde se veneraba a Posidón y Atenea ${ }^{97}$ y había un heroon dedicado precisamente a un insigne piloto, Frontis, el timonel de la nave de Menelao que había sido sepultado en este lugar y que se ha identificado con un personaje barbudo que aparece pilotando una nave de guerra en un fragmento de una tablilla votiva realizada en arcilla datada en el siglo VIII a.C. ${ }^{98}$. A mi modo de ver los paralelismos son evidentes, si en un lugar donde se venera a Posidón, un piloto "divinizado" y una Atenea asociada a un culto marítimo como Sunio, se desarrollaban competiciones navales, parece plausible que en otro lugar, Falero, donde se daban prácticamente las mismas características, se celebrasen regatas durante una fiesta, en la que sus protagonistas eran nada menos que los timoneles.

Dado que las Cibernesias son unas festividades que se celebran en el mes de Boedromión (septiembre/octubre) coincidiendo, aproximadamente, con el final de la estación navegable más corta que es la que defiende Hesíodo y que sería la más habitual en una época más antigua, es posible que se trate de una festividad que daba por

95 Gardner, «Boat-Races...», 90-97; Head, Historia numorum..., 327; I.R. Arnold, «Local Festivals at Delos», AJA, 37, 1933, 456; H.A. Harris, Sport in Greece and Rome, Londres, 1972, 112, 127; M. Golden, Sport and society in ancient Greece, Cambridge, 2003 (1998), 8-9, 25-26, 34, 164; Romero Recio, Cultos maritimos..., 40, $7 \mathrm{I}$.

96 Lys. 21.5; cf. Hdt. 6.87; L. Deubner, Attische Feste, Berlín, 1932, 215, n. 2; J. Vélissaropoulos, Les nauclères grecs. Recherches sur les institutions maritimes en Grèce et dans l'Orient hellénisé, Ginebra-París, 1980, 229.

97 Cf. S. Aj. 1220; E. Cyc. 293 ss.; Paus. I.I.I. U. Sinn, «Sunion. Das befestigte Heiligtum der Athena und des Poseidon an der "Heiligen Landspitze Attikas"», $A W, 23$, 1992, 175-190. En contra de la existencia del templo de Atenea en Sunio: W.K. Pritchett, Pausanias Periegetes, II, Amsterdam, 1999, 39-45. H.R. Goette también defiende que el templo principal pertenecía a Posidón y no a Atenea como indica

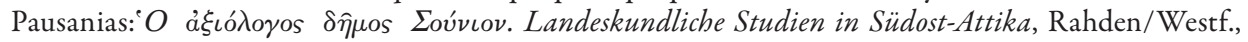
2000, 18-43; Athens, Attica and the Megarid. An Archaeological Guide, Londres, 2001, 203-209. El nexo entre Posidón y Atenea se estrecha en una tradición mitológica recogida por Pausanias (I.I 4.6), pues este señala que un mito de origen libio decía que Atenea tenía los ojos glaucos porque era hija del propio Posidón, cuyos ojos eran también de ese color, y la laguna Tritónide.

98 Hom. Od. 3.278-285; Paus. 10.25.2; J.M. Cook, «Protoattic pottery», $A B S A$, 35, 1934-1935, 173, pl. 4ob; Ch. Picard, «L'hérôon de Phrontis au Sounion», RA, 16, 1940, 5-28; G.S. Kirk, «Ships on geometric vases», $A B S A$, 44, 1949, 119 ss., fig. 7; H. Abramson, «A Hero Shrine for Phrontis at Sounion?», California Studies in Classical Antiquity, I2, 1979, I-19; Kearns, The Heroes of Attica, 41-42; A. Delivorrias (Ed.), Greece and the Sea, Ámsterdam, 1987, n. 62; J.M. Camp, The Archaeology of Athens, New Haven, 2001, 306, fig. 267. 
finalizada la temporada laboral de los pilotos ${ }^{99}$. De hecho, su fundación por Teseo, como recompensa después del fin de un largo y peligroso viaje, apunta en este sentido. Los timoneles habrían encontrado en las Cibernesias la recompensa al trabajo de la temporada naviera, si bien ésta se prolongaría en una época más reciente hasta el mes de noviembre, quedando entonces la fiesta desprovista de su contenido original. Sería factible entonces que, dada la antigüedad de la celebración, su origen pueda encontrarse en un momento en el que los aristócratas, tal vez los naucraroi atenienses ${ }^{100}$, poseían los barcos y practicaban con ellos todos los aspectos relacionados con la navegación (guerra, piratería, comercio, colonización) ${ }^{\text {Ior }}$. Sería en un momento posterior, cuando la estación navegable se había ampliado y el comercio se había desvinculado de la aristocracia cuando un genos de (comerciantes) fenicios se hubiese hecho cargo de un sacerdocio relacionado con esta fiesta ${ }^{102}$. Tal vez ahí radicase el conflicto con los falereos que deseaban "recuperar" el sacerdocio de Posidón y la organización de las fiestas. Las Cibernesias se habrían restringido entonces cada vez más a un grupo social concreto por lo que, al no contar con una amplia participación ciudadana, parece lógico que tampoco dispongamos de demasiada información -ni arqueológica ni literaria- sobre ella.

\section{I.2. Ploiaphesia $o$ Navigium Isidis}

En algunos puertos del Mediterráneo se celebraba una fiesta que abría oficial-

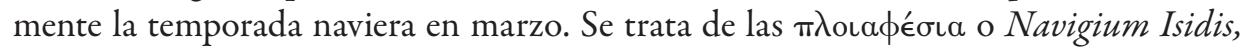
festividad constatada desde la época helenística hasta el siglo IV. Es Apuleyo en sus Metamorfosis (II.5.5 y II.9-17) quien nos relata con detalle el funcionamiento de esta celebración en el puerto corintio de Cencreas. La festividad aparece también mencionada en otras fuentes: el calendario de Furio Dionisio Filócalo, datado en el 354, donde se

99 En el apartado II.3 tendré ocasión de mencionar qué fiesta creo que pudo ser la que inaugurase la estación navegable corta que, según Hesíodo, comenzaba en julio/agosto.

Io० M. Romero Recio, «Problemas sobre los antecedentes arcaicos del naukleros», Xaî $\rho \epsilon$, Homenaje al Prof. Fernando Gascó, Sevilla, 1997, 85-93.

Ior Sobre la participación de la aristocracia en la actividad comercial durante el período arcaico remito a: D.W. Tandy, Warriors into Traders: The Power of the Market in Early Greece, Berkeley, 1997.

IO2 C.M. Reed ha vuelto a defender que el comercio en la Atenas clásica estaba en manos de hombres pobres o extranjeros: Maritime traders in the Ancient Greek World, Cambridge, 2004 (2003), especialmente 62 ss. para ver la evolución desde el período arcaico. 
recogen los menologios rústicos ${ }^{103}$, Sobre los meses de Juan Lido (4.45), las Instituciones divinas de Lactancio (I.II) y las Instituciones militares de Vegecio (4.39) ${ }^{104}$.

La documentación indica que la fiesta tenía lugar el 5 de marzo, si bien se ha apuntado también el día 9 del mismo mes ${ }^{105}$. Sabemos con seguridad que además de en Cencreas, se celebró en Eretria -que arroja la fecha más antigua para el s. I a.C. ${ }^{106}$-, Atenas ${ }^{107}$, Bizancio ${ }^{108}$ y otros puertos del Imperio ${ }^{109}$. En la inscripción de Eretria donde se constata esta celebración aparece una dedicatoria a los dioses egipcios realizada por

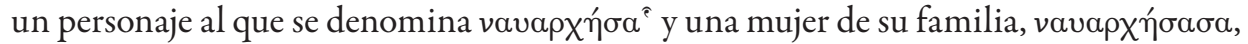
lo que viene a corroborar la participación de los navarcas -personaje también mencio-

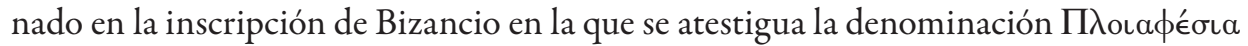
por primera vez- y de las mujeres en la fiesta que reabre la navegación ${ }^{110}$. Ahora bien, es necesario tener en cuenta que, aunque tradicionalmente se ha considerado que la faceta de Isis como diosa de la navegación es de origen grecorromano, algunos estudios apuntan en otra dirección abogando por un origen egipcio del Navigium Isidis basándose en los Textos de las Pirámides y en la rememoración que la celebración de la fiesta podía hacer de la travesía marina realizada por Isis tratando de recomponer el cadáver de su esposo Osiris ${ }^{111}$.

I03 CIL I' 260, 280-28I = VI, 2305, 2306. Sobre este calendario cf. D. Levi, «The Allegories of the Months in Classical Art», Art Bulletin, 23.4, 1941, 25I-291, concretamente sobre marzo: 257-259; H. Stern, Le calendrier de 354. Étude sur son texte et sur ses illustrations, París, 1953, 225.

I04 Cf. Auson. VII Egl. 24, v. 23-24.

Ios S. Weinstock, «A New Greek Calendar and Festivals of the Sun», JRS, $38,1948,38$.

106 L. Vidman, Sylloge inscriptionum religionis isiacae et sarapiacae (SIRIS), Berlín, 1969, n. 80-82. Cf. Ph. Bruneau, «Existe-t-il des statues d'Isis Pélagia», $B C H$, 98, 1974, 341. Sobre Isis marina: L. Bricault, Isis, Dame des flots, Lieja, 2006.

I07 E.R. Williams, «Isis Pelagia and a Roman Marble Matrix from the Athenian Agora», Hesperia, 54, I985, I09-II9.

I08 SIRIS, n. 130; L. Robert, Hellenica, X, 1955, 24-26; Bruneau, «Existe-t-il des statues...», 340-34I. 109 A. Alföldi, A festival of Isis in Rome under the Christian Emperors of the IV $V^{\text {th }}$ Century, Budapest, 1937, esp. 42-58; Merkelbach, Isisfeste...; M. Malaise, Les conditions de pénétration et de diffusion des cultes égyptiens en Italie, EPRO, 23, Leiden, 1972, 217-221; E.R. Witt, Isis in the Graeco-Roman World, LondresSouthampton, 1971, 177 ss.; F. Dunand, Le culte d'Isis dans le basin oriental de la Méditerranée. III. Le culte d'Isis en Asia Mineure. Clergé et rituel des sanctuaires isiaques, Leiden, 1973, 223-230; Bruneau, «Existe-t-il des statues...», 340-34I; J.G. Griffiths, The Isis-Book (Metamorphoses, book XI). Apuleios of Madauros, EPRO, 39, Leiden, 1975, 31-46; R. Turcan, Les cultes orientaux dans le monde romain, París, 1989, II 4 ss.; A. Göttlicher, Kultschiffe und Schiffskulte im Altertum, Berlín, 1992, I16-117.

ino Dunand, Le culte d'Isis..., III, 223-224.

II B. Rossignoli, « Le aretalogie: I manifesti propagandistici della religione isiaca», Patavium, 9, 1997, 76; J. Alvar, Los misterios. Religiones «orientales» en el Imperio Romano, Barcelona, 2001, 218. R. Merkelbach (Isisfeste in griechisch-römischer Zeit, Daten und Riten, Meisenhem, 1963, 36-4I) identifica 
Además de las fuentes literarias se ha identificado el motivo del Navigium Isidis -provocando siempre animadas polémicas- en algunas manifestaciones artísticas, como en un mosaico de Antioquía ${ }^{\mathrm{I1}}$, en un relieve del Vaticano ${ }^{\mathrm{II}}$, en el iseo de Pompeya, en Ostia, en Herculano y en el Aventino ${ }^{114}$.

Apuleyo nos ha transmitido el relato más completo sobre el funcionamiento de esta festividad en el puerto de Cencreas. Precedida por una descripción de la regeneración vegetal y animal que tiene lugar el día en el que se celebra la fiesta (II.7), detalla el autor las características de la comitiva que acompañaba la procesión, compuesta por mujeres, coros de cantantes e instrumentistas, iniciados, sacerdotes -uno de ellos sostenía una naveta de oro- e imágenes de dioses. Continúa describiendo cómo en procesión se dirigían hasta la orilla del mar donde estaba esperando un barco de nueva construcción decorado con pinturas y en cuya vela había una inscripción bordada en letras de oro donde se solicitaba una feliz apertura de la estación navegable. El sumo sacerdote entonaba sus oraciones, purificaba la nave -con una antorcha encendida, un huevo y azufre- y la consagraba a Isis. A continuación, se realizaba una libación con un puré de leche sobre las aguas del mar y se botaba la nave que iba repleta de ofrendas votivas. Cuando el barco dejaba de ser visible desde la orilla, la comitiva regresaba al templo donde se volvían a colocar las imágenes en su sitio. Uno de los sacerdotes pedía por la felicidad del emperador, del senado, del orden ecuestre, del pueblo romano, de los marineros y de las naves, finalizando la oración con la fórmula griega del ritual que

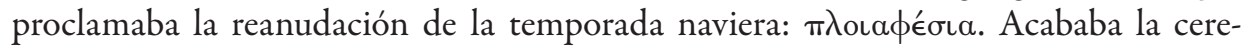
monia cuando los asistentes, embargados por la alegría, depositaban ante la imagen de plata de la diosa Isis ramos y coronas.

el Navigium Isidis con las Kikellia mencionadas en el decreto de Canopo, cuyo motivo principal era la partida del barco de Osiris y su regreso a Canopo; en contra: Dunand, Le culte d'Isis..., III, 229-230.

II2 Levi, «The Allegories of the Months ...», 258-259; Antioch Mosaic Pavements, I, PrincetonLondres-La Haya, 1947, 37, 164-165. En contra: Stern, Le calendrier de 354 ..., 225.

II3 Stern, Le calendrier de 354..., 280, n. 9.

II 4 Malaise, Les conditions de penetration..., 221; V. Tran Tam Tinh, Essai sur le culte d'Isis à Pompéi, París, 1964, 100 ss. 
El culto de Isis está constatado en Corinto tanto a través de las fuentes literarias como de la arqueología ${ }^{\mathrm{II}}$. Pausanias (2.4.6) cuenta que subiendo al Acrocorinto había recintos consagrados a Isis, una Pelagia y la otra Egipcia, junto a dos de Serapis, uno de ellos llamado «en Canobo», y un templo de Afrodita (Paus. 2.5.I; Str. 8.6.20-2I), tres cultos indisolublemente unidos al mundo de los navegantes. Además de este santuario dedicado a Isis como Pelagia, la diosa tenía otro espacio consagrado en Cencreas. Pausanias de nuevo (2.2.3) señala que en Lequeo había un templo de Posidón y una imagen de bronce y que en el camino desde el Istmo se podía ver un templo de Ártemis y un xoanon, y en Cencreas, un templo de Afrodita y una imagen de mármol «y después de él, en el muelle que se adentra en el mar, una de bronce de Posidón, y en el otro extremo del puerto, santuarios de Asclepio y de Isis» (trad. Ma.C. Herrero, BCG, Madrid 1994). Teniendo en cuenta el epíteto que acompaña a la divinidad, la ubicación de los santuarios y la noticia de Apuleyo, es evidente que Isis sería venerada en el Acrocorinto y en Cencreas como una divinidad marina.

Contamos, por otra parte, con numerosas fuentes que aluden al carácter marino de la diosa, entre otras, algunos conocidos Himnos de Isis. El Himno de Andros (s. I a.C.) es uno de los más elocuentes pues pone en boca de la diosa el siguiente discurso: «Yo soy la primera que ha caminado la penosa ruta del mar hasta el final» (1.35). «Cuando el tiempo era bueno los barcos podían navegar a través de Anfítrite, sus proas se oscurecían con la sequía del invierno, después de que yo hubiera abierto los grises brazos de Tetis con una sonrisa, sonrojadas mis alegres mejillas. Por las profundidades navegables, cuando el corazón me lo pedía, seguía mi camino sin rumbo.

Precipitándose en todas direcciones con oscuro bramar, el océano daba profundos rugidos desde su santuario más íntimo, en sus profundas cavernas. Fui la primera que guió la quilla del rápido barco, sus velas al viento, mientras cabalgaba en su cubierta de madera sobre las olas. La hermosa familia de Doris comenzó su tortuosa danza cuando el mar fue puesto bajo control por rápidos veleros de pino. Sus mentes se estremecieron de estupor mientras contemplaban

is F. Dunand, Le culte d'Isis dans le basin oriental de la Méditerranée. II. Le culte d'Isis en Grèce, Leiden, 1973, 17-18 ; D.E. Smith, «The Egyptian cults at Corinth», Harvard Theological Review, 70, 3/4, 1977, 20I ss. 
a una tripulación que nunca antes habían visto...» (1. I46-I58)

$\ll$ En el principio traje la isla hundida

desde el abismo pantanoso a la luz» (1. I60-I6I);

«sobre el espumoso Nereo,

que sacude su tridente,

coloco la espuma refulgente y su oleaje tonante

golpea la costa de acantilado desnudo» (1. 164-167) ${ }^{116}$.

Asimismo, en el Himno de Cime (ss. I-II d.C.) aparece como señora e inventora de la navegación -también en el de Ios (s. III d.C. $)^{117}$-, señora de ríos, vientos y mares, apaciguadora del mar, desencadenadora de tormentas ${ }^{118}$, y reina del mar en el de Cirene (IO3 d.C.) ${ }^{119}$. Su poder sobre los vientos también se destaca en la obra de Luciano (DMar. 7) y Apuleyo (met. II.5.I), tal vez por eso se le atribuya, además, la invención de las velas (Hyg. fab. 277; Cassiod. var. 5.17), sin duda toda una serie de características que hacen de Isis una de las divinidades que más méritos había hecho para inaugurar con una fiesta la estación navegable ${ }^{120}$. No es de extrañar, por tanto, que encontremos epítetos como Pelagia -mencionado ya más arriba-, Euplea y Faria -con un santuario en Alejandría- acompañando a la diosa ${ }^{121}$, que reciba como ofrendas lámparas en forma de barco $^{122}$ y que los marineros le dirijan dedicatorias de agradecimiento o de solicitud de

II6 Traducción de E. Muñiz, Himnos a Isis, Barcelona, 2006, 100-102.

117 Sylloge Inscriptionum Graecarum ${ }^{3}$ 267; Muñiz, Himnos a Isis, 92.

II8 IG XII Suppl. 98-99; Muñiz, Himnos a Isis, 73-74, 85-86.

I19 $S E G, I X$, 1944, 192; Muñiz, Himnos a Isis, 138 .

I20 Cf. D. Müller Aegypten und die Griechischen Isis-Aretalogien, ASAW, 53.1, Berlín, 1961, 41-42, 6I-67; Tran Tam Tinh, Le culte d'Isis..., 98 ss.; Romero Recio, Cultos maritimos..., 17, 48, 82, 91, 93, 105, 109, I28, I3I, I33, I 4I, I48, I58.

I2 I Ph. Bruneau, «Isis Pélagia à Délos», $B C H, 85$, 1961, 435-446; «Isis Pélagia à Délos (compléments)», $B C H, 87$, 1963, 30I-308; «Existe-t-il des statues...», 333-38I; «Deliaca, 25 -Isis Pélagia (IV) ou l'horreur de l'époque sceptique», $B C H$, 102, 1978, 152-16I ; C. Picard, «Lampes d'Isis Pélagia et Euploia: à Délos et ailleurs», $R A$, 1962, 228-230; Smith, «The Egyptian cults at Corinth», 228-229; M.H. Blanchaud, «Un relief thessalonicien d'Isis Pélagia», $B C H$, 108, 1984, 709-7II; Williams, «Isis Pelagia and a Roman Marble...», I09-I19; E. Miranda, «Osservazioni sul culto di Euploia», MGR, I4, I989, I37-138. Representaciones en monedas de Alejandría : S. Handler, «Architecture on the Roman Coins of Alexandria», AJA, 75, 1971, 58-6I, pl. II.2 ; J. Aliquot, «Aegyptiaca et Isiaca de la Phénicie et du Liban aux époques hellénistique et romaine», Syria, 8I, 2004, 217, nt. 75.

122 H. Seyrig, «Antiquités Syriennes: Antiquités de Beth-Maré», Syria, 28, 1951, IOI-I13, pl. IX-XII; Tran Tam Tinh, Le culte d'Isis..., 93 ss. M. Ciceroni («Iside protettrice della navigazione. La testimonianza delle lucerne a forma di barca», en Atti del Convegno Internazionale Anathema, Scienze dell'Antichità, 3-4, 1989-1990, 794-798) cree que la mayor parte de las lucernas que se han conectado con el culto de Isis eran en realidad de uso doméstico y ni siquiera otorga valor al epíteto euploia pues considera que podía 
auxilio, así como tablillas votivas pintadas con las que quieren reconocer su intervención favorable durante el naufragio como cuenta Juvenal ${ }^{123}$.

Además de los santuarios dedicados a Isis en Corinto a los que aludía más arriba, encontramos en el Mediterráneo otros templos consagrados a esta divinidad en lugares tan asociados a la navegación como el Pireo -datado en el 333/332 a.C. ${ }^{124}$-, Trecén y Metana, cerca de una zona donde abundaban los monstruos marinos y los tiburones (Paus. 2.34.I $)^{125}$. También en Hermíone, Pausanias indica (2.34.IO-II) que en el extremo de la lengua de tierra había un santuario de Posidón, otro de Atenea, de Helio, de las Cárites, y de Serapis e Isis, y recintos donde se celebran los secretos de Deméter. Los Cabiros, Afrodita Euplea, Isis o Serapis encontraron su espacio en el entramado religioso del puerto por su faceta de protectores de los navegantes. Por otra parte, sabemos que el culto de la diosa - principalmente por su dimensión marina- debió alcanzar gran importancia en Atenas a partir sobre todo del s. II a.C., hasta el punto de que en la aretalogía de Maronea (II-I a.C.) se dice que ésta era su ciudad favorita ${ }^{126}$.

Aunque la festividad está constatada en un período tardío resulta difícil imaginar que antes de que apareciese en el calendario religioso, no se celebrasen otro tipo de ceremonias asociadas a la apertura de la estación navegable en honor de otras divinidades de los navegantes en los puertos de la Antigüedad. De hecho, en el Egipto ptolemaico encontramos a Afrodita venerada como diosa del mar y al mismo tiempo, como ya hemos visto que sucede en otros lugares, del amor ${ }^{127}$. Dunand ya apuntaba que, tomando como base el relato de Apuleyo, resultaba difícil determinar qué elementos

ser empleado «come generica forma augurale di buona conduzione della vita». Sobre lucernas con la imagen de la diosa: Picard, «Lampes d'Isis Pélagia et Euploia...», 228-230; Smith, «The Egyptian cults at Corinth», 222; Williams, «Isis Pelagia and a Roman Marble...», I19, n. 76.

I23 Ivv. sat. 12.26-28; schol. Ivv. I2.27-28; Tib. I.3.23-24, 27-28; Anth. Pal., 6.231. Cf. Bruneau, «Isis Pélagia à Délos», 446. Cf. para dedicatorias delias a Isis marina: ID 2128 (IO5/104 ó 104/103 a.C.), 2153 (Isis Euplea, I07-I06 ó I04-I03 a.C.).

I2 4 SIRIS, n. I = IG II/III², 337; T.A. Brady, «The Reception of the Egyptian Cults by the Greeks (330-3I BC)», University of Missouri Studies, IO, 1935, 20-42; F. Dunand, Le culte d'Isis..., II, 4-5; R. Garland, The Piraeus. From the Fifth to the First Century B.C., Londres, 1987, I0I-138.

I25 En general, sobre el culto de Isis en ámbito griego véase la obra de Dunand, Le culte d'Isis...vols. II y III. I26 Y. Grandjean, Une nouvelle arétalogie d'Isis à Maronée, Leiden, 1975, 134, 39-40; Muñiz, Himnos a Isis, ro5. Sobre el culto de Isis en Atenas: SIRIS, n. $3=I G$ II $/ \mathrm{III}^{2}, 4692$; S. Dow, «The Egyptian Cults in Athens», HThR, 30, 1937, 183-232; J.J. Pollit, «The Egyptian Gods in Attica: Some Epigraphical Evidence», Hesperia, 34, 1965, I25-128; Dunand, Le culte d'Isis ..., II, 4 ss. Véase también: Williams, «Isis Pelagia and a Roman Marble...», I09-I19; D. Plácido, «El culto de Isis en Atenas durante el Imperio Romano», en R. Rubio (Ed.), Isis. Nuevas perspectivas, Madrid, I996, 7-II.

I27 S. Barbantani, «Goddess of Love and Mistress of the Sea. Notes on a Hellenistic Hymn to ArsinoeAphrodite (P. Lit. Goodsp. 2, I-IV) », Ancient Society, 35, 2005 , 135-I65. 
pertenecían a la fiesta propiamente isíaca, y cuáles eran restos de una ceremonia más antigua independiente del contexto egipcio de la cual el Navigium Isidis era heredero ${ }^{128}$. En la festividad de las Ploiaphesia se celebran unos rituales que eran bien conocidos por los navegantes desde hacía siglos y más en lugares, como en Eretria, donde los viajes marítimos para comerciar o colonizar habían sido tan frecuentes desde época arcaica. Las ofrendas, plegarias, libaciones y purificaciones precedían -y concluían- todas las singladuras, culminando en una festividad que aglutinaba las costumbres religiosas que los marineros habrían ido desarrollando desde época minoica. Así pues, no creo que haya que esperar al período grecorromano para encontrar algunas ceremonias asociadas al inicio de la estación marinera. Las manifestaciones atenienses, fundamentalmente, pero también otras, son esclarecedoras en este sentido.

\section{II. ¿Por qué no son fiestas vinculadas al mar?}

El propósito de este apartado, que se inicia en íntima relación con el I.2, es poner de manifiesto los elementos vinculados al ámbito marítimo que existen en algunas fiestas del calendario litúrgico griego.

\section{II.I. Fiestas en torno al inicio de la temporada naviera}

Según B. Sergent, en el mes po-ro-wi-to o plowistos, que aparece en una tablilla de Pilos y se correspondería con el mes Muniquión ${ }^{129}$, tenía lugar una serie de celebraciones que se vinculaban a la navegación y por tanto a la apertura de la temporada naviera, algo que ya había defendido L.R. Palmer ${ }^{130}$. Desde luego, no sería extraño que tanto durante la época minoica, como durante el período micénico, etapas de gran actividad ultramarina ${ }^{131}$, se hubiesen desarrollado festividades asociadas al ámbito náutico. Existen, además, otros elementos que apuntan a la existencia de cultos y rituales vinculados a la navegación durante la Edad del Bronce.

I28 Dunand, Le culte d'Isis ..., III, 227, 230.

I29 B. Sergent, «Héortologie du mois plowistos de Pylos», DHA, I6.1, 1990, 175-217.

130 L.R. Palmer, «A Mycenaean Calendar of Offerings (PY Kn O2)», Eranos, 53, 1955, IO-I2; The interpretation of the Mycenaean Greek texts, Oxford, $1963,242-265$.

I3I Puede verse sobre el tema, entre otros, N. Marinatos (ed.), The Minoan Thalassocracy. Myth and Reality, Estocolmo, 1984; E.H. Cline, Sailing the wine-dark sea. International trade and the late Bronze Age Aegean, Oxford, 1994. 
Por una parte, tenemos constatada la existencia de santuarios minoicos costeros situados en lugares de fácil visibilidad desde el $\operatorname{mar}^{132}$. Por otro lado, contamos con la presencia de modelos de barcos en el interior de sarcófagos del MR IIIb ${ }^{133}$, de tumbas desde el Minoico Antiguo ${ }^{134}$ y en santuarios a partir del Minoico Medio ${ }^{135}$. Además, se ha encontrado un número considerable de sellos en los que aparecen naves y, más concretamente, ejemplares en los que se puede leer el nombre de divinidades marinas como Ino-Leucotea y Tetis, otros donde se representa una figura femenina junto a un barco y un número inferior donde se puede ver un navío que transporta un altar y un árbol, y en el que viaja una figura humana haciendo un gesto de adoración ${ }^{136}$. Estos santuarios y estas escenas parecen estar aludiendo a un culto, una divinidad e incluso a una festividad vinculada al mar ${ }^{137}$, tal vez la misma que estaría representada en los frescos de Akrotiri ${ }^{138}$. L.B. Lawler ya defendió la existencia de una danza que los marineros realizarían probablemente desde época minoica buscando la salvación en el mar y, en algunas ocasiones, asociada a un árbol con la pretensión de desviar hacia este elemento los malos augurios ${ }^{139}$. En mi opinión, estas representaciones podrían estar aludiendo a una festividad donde la divinidad se transportase en una nave como luego sucederá en fiestas como las Panateneas o las Antesterias que analizaré en el apartado II.3, y que pueden ser el recuerdo de un tiempo en el que deidades como Atenea o Hera viajaban con los héroes -Odiseo o Jasón- ayudándoles en su viaje.

I32 K. Nowicki, «Minoan Peak Sanctuaries: Reassessing their origins», en R. Laffineur, R. Hägg (eds.), Potnia. Deities and Religion in the Aegean Bronze Age. Proceedings of the $8^{\text {th }}$ International Aegean Conference, Göteborg University, I2-I5 April 2000, Lieja-Austin, 200I, 3I-38.

133 D. Gray, Archaeologia Homerica, I.G, Seewesen, Göttingen, 1974, 47, pl. XI.

134 S. Marinatos, «La marine créto-mycénienne», $B C H$, 57, 1933, 173; Gray, Archaeologia Homerica 1974, n. Ai, Ais; P.F. Johnston, Ship and boat models in Ancient Greece, Annapolis, 1985, II ss.

I35 Johnston, Ship and boat models..., I2-13; L. Basch, Le musée imaginaire de la marine antique, Atenas, 1987, 115, fig. 225 .

136 Sobre estos motivos traté ya en un trabajo anterior al que remito para los detalles sobre estos sellos y la bibliografía especializada: Cultos maritimos..., 7-9.

I37 Ch. Boulotis, «La déesse minoenneà la rame-gouvernail», en H. Tzalas(Ed.), Tropis I. It International Symposium on Ship Construction in Antiquity, Piraeus 1985, Atenas, 1989, 55-73. Ch. Sourvinou-Inwood («Boat, Tree and Shrine: The Mochlos Ring and the Makrygialos Seal», Kadmos, 28.2, 1989, 97-100) cree que no se trata de la representación de un culto real.

138 Cf. Ch. Boulotis, «The Aegean Area in Prehistoric Times: Cults and Beliefs about the Sea», en: Greece and the Sea, Delivorrias, A. (Ed.), Amsterdam, 1987, 26-28; H. Tzalas (Ed.), «La déesse minoenne à la rame-gouvernail», en: Tropis I. I It International Symposium on Ship Construction in Antiquity, Piraeus 1985, Atenas, 1989, 58.

139 L.B. Lawler, «The Dance of the Ancient Mariners», TPAPhA, 75, 1944, 20-33. 
Por otro lado, y como ya he tenido ocasión de señalar ${ }^{140}$, las fiestas asociadas a la partida y regreso del viaje de Teseo también deben vincularse a las celebraciones que inauguran y cierran la estación navegable. Otros autores ya han hecho hincapié en que en la reelaboración del mito de Teseo que se lleva a cabo en Atenas hacia finales del siglo VI comienzos del V, la introducción de episodios en los que se trata de mostrar la filiación entre el héroe y Posidón, tiene que ver con la importancia que los atenienses están otorgando al dominio marítimo a partir de las Guerras Médicas ${ }^{141}$. La victoria sobre Minos representaría incluso la justificación de la hegemonía naval de Atenas en el Egeo ${ }^{142}$. Sin embargo, creo que hay toda una serie de datos que invitan a pensar que en relación con la gesta cretense de este héroe se habrían desarrollado algunas celebraciones vinculadas al mar desde una época mucho más antigua.

Teseo parte hacia Creta en Muniquión (abril/mayo), aproximadamente cuando se abre con la primavera la estación navegable. Puesto que el 6 de Muniquión -el día en el que el héroe deposita la rama de olivo (hiketeria) como suplicante en el Delfinio y sacrifica una cabra en honor de Afrodita antes de zarpar (Plu. Thes. I8.I-3)- las jóvenes atenienses continuaban acudiendo al templo de Apolo Delfinio y Ártemis Delfinia (Plu. Thes. 18.2; Poll. 8.119) ${ }^{143}$, es posible que estos rituales se inscribiesen dentro de un sistema de celebraciones que giraba en torno al inicio oficial de la estación navegable. Casualmente, o no, en esa misma fecha los trierarcos realizarán un sacrificio en honor de Ártemis Muniquia y partirá la theoria de Delos en el "legendario" barco de Teseo o en uno parecido ${ }^{144}$. Además, sabemos que el culto de Apolo Delfinio, de origen cretense, es muy antiguo y se asocia al mar y a la navegación ${ }^{145}$. En el Himno homérico, Apolo Delfinio se metamorfosea en un delfín para acompañar hasta Delfos a unos marineros cretenses que, como Teseo cuando parte hacia Creta, viajaban en una

\footnotetext{
I 40 Más arriba y en: Romero Recio, Cultos maritimos..., I 42 ss.

I4I Calame, Thésée et l'imaginaire athénien..., 425; N. Strawczynski, «Artémis et Thésée sur le skyphos du peintre de Brygos Louvre G 195», Revue archéologique, I/2003, 6 ss.

I 42 W.R. Connor, «Theseus and his city», en P. Hellström, B. Alroth (Eds.), Religion and Power in the Ancient Greek World. Proceedings of the Uppsala Symposium 1993, Boreas 24, Uppsala, II7.

I 43 E. Pfuhl, De Atheniensium pompis sacris, Berlín, 1900, 79; Parker, Polytheism and Society..., 465-466. Sobre la asociación de Ártemis y Apolo en el Delfinio: Poll., 8.ı19; Pherecid., FGrH. 3 F i49; Plu. Mor. 984 a

I 44 Call. Del. 314-315; A. Mommsen, Heortologie. Antiquarische Untersuchungen über die Städstischen feste der Athener, Amsterdam, 1968, 399, 402. Cf. Lawler, «The Dance of the Ancient Mariners», 23 ss. I 45 Cf. h. hom. Ap. 400 ss., 494 . Aunque los primeros templos no parecen remontarse más allá del siglo VIII a.C. Cf. J. Defradas, Les Thèmes de la propagande delphique, París, 1954, 20 ss.; J. Dumont, «Les dauphins d'Apollon», QS, I.I, 1975, 57-85.
} 
nave con velas negras ${ }^{146}$. Todavía en el s. II, Artemidoro indica (Onir. 2.35) que Apolo Delfinio suele anunciar viajes y $\operatorname{traslados}^{147}$.

A favor de la existencia de cultos y celebraciones en torno a dioses asociados al mar en esta zona y vinculado al mito de Teseo está la posible existencia en Falero de un espacio sacro en el que se venerase a esa Afrodita en honor de la cual el héroe había realizado un sacrificio. Ésta, que se identificaba con Pandemos, llevaba el sobrenombre de Epitragia porque la cabra que Teseo le había ofrecido se había vuelto repentinamente macho $^{148}$. Por otra parte, Teseo había ofrecido a Apolo Delio un xoanon de Afrodita que le había dado Ariadna (Plu. Thes. 21; Paus. 9.40.4), ofrenda que debe ser puesta en relación con las dedicatorias que agradecen una óptima travesía ${ }^{149}$. Por consejo de Apolo, Teseo había elegido a Afrodita como compañera de viaje, y una vez en Creta, el héroe se había unido a Ariadna para que, como la diosa había hecho, le ayudase a culminar con éxito la expedición.

Ariadna ocupará ahora el lugar de la diosa, y no sólo eso, se producirá una simbiosis que dará lugar incluso a un culto, el de Ariadna-Afrodita ${ }^{150}$. Pero tanto la heroína como la diosa pasarán a un segundo plano a favor de quien había realizado el encargo de proteger al héroe en el mar, esto es, Apolo. Y es que, antes de zarpar, Teseo había acudido al Delfinio para solicitar la ayuda de Apolo, pero éste, a pesar de ser una divinidad marina, no había actuado directamente como protector durante la navegación, por lo que habría desviado su responsabilidad hacia Afrodita. La diosa entonces no abandonaría al héroe, será él quien, considerando que ha alcanzado con éxito su objetivo, decida prescindir de la ayuda de la diosa: deja a Ariadna en Naxos o en Chipre, y deposita como ofrenda en Delos lo único que aún le une a la divinidad, la estatuilla, volviendo así a mostrar su devoción a Apolo. De hecho, cuando regresa a Atenas, ya no sacrifica en honor de Afrodita como había hecho antes de zarpar, o al menos no se destaca. El héroe celebra los sacrificios que antes de partir había prometido a los dioses

I 46 Véase el apartado II.4.

I 47 M.C. Barrigón («La utilización del mito en la obra de Artemidoro», en Estudios de religión y mito en Grecia y Roma, X Jornadas de Filología Clásica de Castilla y León, Nieto, J.M. (coord.), León, I995, 100 ss.) ha destacado la importancia que otroga este autor a las divinidades marinas.

I 48 Pirenne-Delforge, L'Aphrodite grecque..., 35-37; Connor, «Theseus and his city», II7.

149 Romero Recio, Cultos maritimos..., 86 ss.

I50 En Amatunte se ha descubierto una cavidad que probablemente sea un sepulcro y que podría tratarse de la tumba de Ariadna mencionada por Plutarco (20.4-7), donde se rendía culto a Ariadna-Afrodita: A. Hermary, M. Schmid, «Rapport sur les travaux de l'École Française à Amathonte de Chypre en 1988. Le sanctuaire d'Aphrodite», $B C H$, I13, 1989, 855-859. Otra tradición indica que Ariadna fue enterrada en el templo de Dioniso Cresio en Argos, casualmente muy cerca de un santuario dedicado a Afrodita Urania (Paus. 2.23.8). 
en el puerto (Plu. Thes. 22.2) y acude a presentar la eiresione a Apolo Delfinio, el último agradecimiento a la divinidad que le había otorgado los instrumentos necesarios para llevar a buen fin su viaje. Puede incluso que esa desvinculación de Ariadna-Afrodita fuese el verdadero desencadenante del trágico final de Egeo, pues se subraya que Teseo había olvidado cambiar las velas porque aún estaba afectado por la ausencia de Ariadna (Paus. I.22.5).

El culto a Afrodita en Falero pudo basarse, por tanto, en los mismos parámetros que habían originado su nacimiento, es decir, en su faceta de protectora de la navegación, una deidad positiva a la que se dedican sacrificios antes de zarpar. Creo que en este sentido apunta también el hecho de que encontremos un culto de Afrodita Pandemos unido al de Afrodita Pontia, claramente vinculada a la devoción de los navegantes, en $\operatorname{Cos}^{151}$, y de nuevo se podría apuntar a una asociación entre la prostitución amparada por una Afrodita Pandemos y la navegación asegurada por la misma diosa bajo el epíteto Pontia, en un dueto similar al ateniense Afrodita Pandemos/Urania que mencionaba más arriba ${ }^{152}$.

Por otra parte, en el mes de Muniquión se celebraba en el entorno de Atenas otra fiesta donde las connotaciones asociadas al mar son evidentes y que, bajo mi punto de vista, pudo estar asociada al inicio de la temporada naviera. Se trata de la fiesta Muniquia celebrada en honor de Ártemis el día I6 del mencionado mes y que será más conocida por incorporar en el siglo V a.C. la conmemoración de la victoria naval de Salamina (Plu. Mor. 349f). La diosa tenía un santuario en Muniquia, uno de los puertos de Atenas cuya fundación se atribuía a Muniquio -legendario rey del Ática-, con un culto que se remonta al siglo X a.C., y otro en Salamina (Paus. I.36.I) ${ }^{153}$. H.W. Parke relaciona con esta fiesta una leyenda que alude a la intervención de la diosa ${ }^{154}$. Según ésta, se estaba celebrando el sacrificio de una cabra en el santuario de Ártemis Muniquia -Parke cree que, probablemente, el día de su festividad- cuando entró una osa en el templo a la que dieron muerte los asistentes. La diosa, enfadada, envió una plaga y los

I5I R. Parker, «The cult of Aphrodite Pandamos and Pontia on Cos», en H.F.J. Horstmanshoff et al. (eds.), Kykeon: Studies in Honour of H.S. Versnel, Leiden, 2002, 143-160.

I52 Véase nota 88.

I53 L. Palaiokrassa, «Neue Befunde aus dem Heiligtum des Artemis Munichia», $A M$, I04, I989, I-40; D’Onofrio, «Sanctuari “rurali”... », 66; F. de Polignac, «Sanctuaries et société en Attique géometrique et archaique», en S. Verbanck-Piérard, D. Viviers (eds.), Culture et cité. L'avènement d'Athènes à l'époque archaïque, Bruselas, 1995, 77; M.K. Langdon, «Cult in Iron Age Attica», en S. Langdon (Ed.), New Light on a Dark Age, Columbia-Londres, 1997, II8; A. Mazarakis Ainian, From rulers' dwelings to temples. Architecture, religion and society in Early Iron Age Greece, Jonsered, 1997, 315.

${ }_{15} 4$ Suda, s.v.' E $\mu$ ßapos; App. Prov. 2.54; Eust., ad Il. 268, 24 ss. Parke, Festivals of the Athenians, 138. 
atenienses buscando una solución consultaron el oráculo. Éste les comunicó que la diosa se aplacaría si alguien sacrificaba a su hija en su honor. Un tal Embaros propuso asumir el sacrificio de su hija si a cambio él y su familia obtenían el sacerdocio vitalicio del santuario de Ártemis. Una vez aceptadas sus condiciones ofreció como víctima no a su hija, sino a una cabra disfrazada con sus ropas.

Tenemos otras noticias que aluden a la exigencia de sacrificios humanos por parte de la diosa y alguno de ellos con conexiones importantes con el mar. Sin duda la más conocida es la de Ifigenia. Según el mito, Agamenón había ofendido a Ártemis y ésta le había castigado manteniendo a su flota paralizada por la calma chicha. El adivino Calcante les hizo saber que sólo la muerte de su hija Ifigenia podría complacer a la diosa para que permitiese a los barcos llegar a Troya con viento favorable. Cuando la doncella iba a ser inmolada, la diosa se apiadó de ella y sacrificó en su lugar a un animal que en las fuentes oscila entre una osa, una cierva, una ternera o un toro ${ }^{155}$.

Antes de continuar con los lazos existentes entre Ártemis y la navegación, quisiera aludir a tres aspectos importantes de las Muniquia. En primer lugar, sabemos que durante la fiesta se realizaba una procesión en la que se ofrecían a la diosa unos pasteles llamados amphiphontes que tenían forma circular y estaban decorados con antorchas ${ }^{156}$; en segundo lugar, que según Plutarco (Mor. 349f) la fiesta se celebraba ese día porque Ártemis, como diosa lunar, se habría aparecido a los griegos de Salamina ${ }^{157}$; y en tercer lugar, los testimonios epigráficos confirman que, al menos a partir del siglo II a.C., dentro de las celebraciones propias de esta festividad tenían lugar regatas de barcos sagrados que recorrían la distancia comprendida entre el puerto del Pireo y el puerto de Muniquia. Cuando terminaban, los participantes acudían al santuario de la diosa y realizaban un sacrificio en su honor ${ }^{158}$. Por otra parte, sabemos que en el año 192-193 d.C. se celebró una naumachia en Muniquia durante las mismas fiestas ${ }^{159}$.

I55 A. Ag. 1526; E. IT, 354-358; Or. 23; Apollod. epit. 2.16; 3.21 ss.; Ov. met. 12.24-38; Hyg. fab. 98, 120, 238, 261; Nonn. 13.107; Procl. Chr. I. Cf. Paus. 2.22.6-7; Ant. Lib. 27. Cf. Romero Recio, Cultos maritimos..., IOI-IO2. Sobre las distintas variaciones del mito véase: P. Bonnechère, Le sacrifice humain en Grèce ancienne (Kernos suppl. 3), Atenas-Lieja, 1994, 26 ss. Véase además: S. Georgoudi, «À propos du sacrifice humain en Grèce ancienne: remarques critiques», Archiv für Religionsgeschichte I.I, 1999, 60-82.

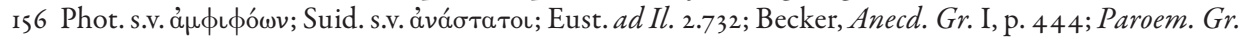
I, p. 402. Cf. Parke, Festivals of the Athenians, 138; R. Osborne, Demos: the discovery of Classical Attika, Cambridge, 1985 , $154-172$.

157 Cf. Mikalson, The sacred and civil calendar..., I43-1 44.

I58 IG II².1006, 1. 29 ss. (I22-I2I a.C.); I0II, 1. I6 (I06-105 a.C.); 1028, 1. 21 (I06-105 a.C.); 1029, 1. I3 (94-93 a.C.); Garland, The Piraeus..., II 4.

I59 $I G \mathrm{II}^{2} .2130,1.49$. 
El carácter fosfórico de Ártemis en Muniquia está corroborado por la existencia de un altar dedicado a Ártemis Fósforo -la portadora de antorchas- dentro de su santuario ${ }^{160}$ y por una noticia de Clemente de Alejandría (I.I60-I63) según la cual Fósforo sirvió de guía en la oscuridad a Trasíbulo para llegar hasta Muniquia. También en Mégara la diosa había ayudado al ejército griego. Pausanias dice que en esta ciudad había una imagen de bronce de Ártemis Soteira (Paus. I.40.2-3), y muy cerca de la fuente de Teágenes, precisamente donde el autor sitúa la presencia de la estatua de la diosa, apareció un relieve de mármol datado en el siglo IV a.C., en el que está representada Ártemis Fósforo portando una antorcha en cada mano ${ }^{161}$. Asimismo, Pausanias cuenta (I.40.2-3) que durante la segunda guerra médica, el ejército de Mardonio había realizado una incursión en Megáride, pero cuando quisieron retirarse a Tebas, Ártemis hizo que cayese la noche y el contingente se equivocó de camino dirigiéndose a la montaña. Pensando que los enemigos estaban frente a ellos, dispararon todas sus flechas contra las rocas. Al día siguiente los megarenses los atacaron matando a la mayoría pues las tropas estaban desarmadas. Esta fue la razón por la que erigieron una estatua de Ártemis Soteira en Mégara ${ }^{162}$. En Pagas había también una imagen de Ártemis Soteira igual que la de Mégara, pues cerca estaba la roca sobre la que dispararon sus flechas los persas (Paus. 1.44.4).

Tanto estas noticias, como los pasteles decorados con antorchas, como el carácter fosfórico y lunar de la diosa que se subraya a propósito de la victoria naval en Salamina son aspectos que se conectan con la guerra ${ }^{163}$ pero también con el mar. Otros autores ya han señalado que Ártemis Fósforo estaría ligada por una parte a las iniciaciones, y por otra a las travesías, a los puertos y al mar y que muchas epíclesis de Ártemis están en relación con una buena travesía ${ }^{164}$. En este sentido desde luego apunta, por ejemplo, el epíteto de Apobateria -en relación con las ofrendas que los marinos realizan al desembarcar- que la divinidad lleva en Eritras, en la costa jónica (IGRom 4.I539), así como la noticia que alude a la fundación del santuario de Ártemis Muniquia en Pigela, cerca de Éfeso, por parte de Agamenón (Str. I4.I.20). Asimismo, se ha destacado que la reformu-

160 J. Threpsiades, en $P A A$, 1935, 190-191, 195; Garland, The Piraeus..., 162.

16I G. Daux, «Chronique des fouilles en 1957», $B C H$, 82, 1958, 692, fig. 37. Sobre las fiestas en honor de Ártemis Soteira: IG VII.6; L. Robert, Études épigraphiques et philologiques, París, 1938, 70-76.

162 Un comentario de este episodio puede verse en, P. Ellinger, La légende nationale phocidienne. Artémis, les situations extrêmes et les récits de guerre d'anéantissement, París, 1993, 224-228.

163 I. Solina, «Era, Artemide e Afrodite in Magna Grecia. Dee armate o dee belliche? », MEFRA, IIO.I, 1998,394 ss.

164 L. Piccirilli, «Le soppracciglia di Artemide», CCC, 3, 1981, 223 ss.; «Artemide e la metis di Themistocle», QS, 13, 1981, 150. 
lación que hacia los años 480-470 a.C. sufre la leyenda de Teseo está destinada a justificar la expansión marítima de la ciudad y su hegemonía. El lazo existente entre el héroe ateniense y la política marítima de Atenas desde las Guerras Médicas se manifestaría en la iconografía a través de la figura de Ártemis, divinidad que parece ser venerada por su ayuda en las expediciones marítimas ${ }^{165}$.

Ártemis comparte con Hécate el apelativo de $\Phi \omega \sigma \phi o ́ p o{ }^{\circ 166}$. Esto hace que frecuentemente se represente a ambas con antorchas en la mano alumbrando a los viajeros ${ }^{167}$. En Bizancio se veneraba a una diosa Fósforo a la que se representaba con grandes antorchas en las manos, y que aún no se ha determinado con claridad si se trata de Ártemis o Hécate, aunque es probable que se trate de esta última teniendo en cuenta el relato de Esteban de Bizancio que tanto recuerda al acontecimiento relatado por Pausanias sobre el ejército de Mardonio al que aludía más arriba ${ }^{168}$. Está constatada además la existencia de un mes llamado Bosporeios, y de una fiesta, las Bosporia, durante las cuales se celebraban carreras con antorchas ${ }^{169}$. Como decía, tengo la impresión de que esta diosa Fósforo no es sólo una divinidad de carácter militar, como se ha sostenido, sino también una deidad asociada a la navegación ${ }^{170}$. Bizancio era una ciudad muy importante en los circuitos comerciales marítimos, además de ser una potencia militar y marítima. Su ubicación a la entrada del Bósforo (nombre derivado, como se ha señalado, de Fósforo) le confería una importancia estratégica excepcional. No sería, por tanto, extraño que la diosa Fósforo portadora de antorchas fuese en realidad una divinidad vinculada a los faros, al fuego que debía alumbrar la entrada al puerto. De hecho, tanto el puerto como las fiestas que se celebraban al menos desde el siglo III a.C. llevaban su nombre. Creo que la noticia que encontramos en Pausanias (2.25.4)

165 Strawczynski, «Artémis et Thésée...», 3-24. Teseo funda un santuario en honor de Ártemis Soteira en Trecén al volver de Creta (Paus. 2.31.I).

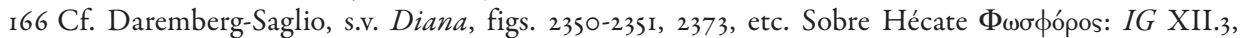
$42 \mathrm{rb}$; cf. E. Hel. 569; Ar. Th. 858; $I G \mathrm{XII}^{1}$, 91 4; L. Robert, «Relief d'Hécate à Satala», en: Hellenica X, París, 1955, I13-117, pl. XV.I; Th. Kraus, Hekate. Studien zu Wesen und Bild der Göttin in Kleinasien und Griechenland, Heidelberg, 1960, II, 28, 78, 85, 88. Lucernas con una diosa Fósforo que podría ser tanto Ártemis como Hécate se encontraron en Delos: Ph. Bruneau, Les Lampes, Exploration archéologique de

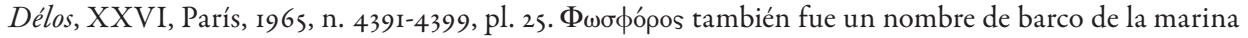
ateniense: $I G \mathrm{II}^{2} .16 \mathrm{I} 2,1.107,334$; I6I3, 1. 55 .

167 Ártemis Ferea era venerada en Argos, Sición y Atenas (Paus. 2.10.7; 23.5) y en las monedas de Sición se la representaba con las dos antorchas. Hécate alumbra con antorchas a Deméter: h. Hom. Dem. 53.

168 Est. Byz. s.v. Bóortopos; Hesych. FGrH 390 F 1, 26-27.

169 L. Robert, «Index commenté des noms de personnes», en N. Firatti, Les stèles funéraires de Byzance gréco-romaine, París, 1964, 154-159.

170 Romero Recio, Cultos marítimos..., 65. 
acerca de una fiesta de antorchas celebrada por los argivos y que se relaciona con un acontecimiento muy antiguo asociado a la llegada por mar de Dánao y a la salvación de un peligro, puede reforzar este vínculo entre la antorcha, la navegación y las festividades asociadas a este ámbito.

Por otra parte, Ártemis y Hécate no sólo comparten los mismos apelativos, sino

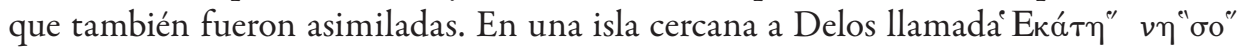
-de difícil identificación aunque posiblemente se trate de Renea o del islote llamado Rhevmatiaris- se celebraban sacrificios en honor de Ártemis-Hécate ${ }^{171}$. También en Tasos fue venerada Ártemis Hécate ${ }^{172}$. Pausanias (I.43.I) indica que, según el Catálogo de las Mujeres de Hesíodo, Ifigenia se convirtió en Hécate por voluntad de Ártemis. Por otro lado, Ártemis Soteira y Hécate compartieron modelos iconográficos comunes ${ }^{173}$, y ambas aparecen en Delos con el apelativo de Soteira, epíclesis que para Hécate se constata sobre todo en Asia Menor, en las islas, pero nunca antes de la época helenística $^{174}$. Además, y esto es muy importante en relación con el carácter lunar que Plutarco atribuye a Ártemis al ayudar a los griegos en Salamina, la diosa se asimiló a la Luna (A. Suppl. 676-677; Theocr. Idil. 2.33 ss.). Estas identificaciones también pasaron al mundo romano donde Ártemis, asimilada a Diana, es la misma que Proserpina, Hécate, la Luna o Lucina ${ }^{175}$.

Según algunos autores, la fiesta del día 16 de Muniquión se celebraba en honor de una Ártemis asociada a Hécate ${ }^{176}$. P. Brulé ya subrayó que la Ártemis de Muniquia podía llamarse Hécate y observó que muchos de sus santuarios se encuentran al borde

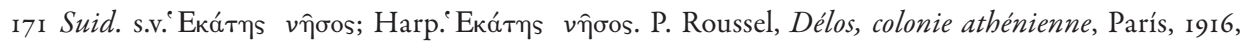
217-219; J. Tréheux, «Ortygie», BCH, 70, 1946, 566-571; H. Gallet de Santerre, J. Tréheux, «Chronique des fouilles 1946», BCH, 71-72, 1947-1948, 4I4-4I8; H. Gallet de Santerre, Délos primitive et archä̈que, París, 1958, 155.

172 Duchêne, La stèle du port..., 72-74.

173 G. Siebert, «Artémis Sôteira à Délos», $B C H$, 90, 1966, 456-457.

I74 Ártemis: IG XI.4, I276; ID 1909, 2378, 2379; Siebert, «Artémis Sôteira à Délos», 447-459. Hécate: ID 2448; L. Robert, «Dédicace de Cyzique», en: Hellenica X, París, 1955, I15, n. 2; Kraus, Hekate..., n. 206-2ıо; H. Sarian, «Artemis e Hecate en Delos: apontamentos de iconografía religiosa», Rev. Do Museu de Arqueología e Etnología, 8, 1998, I 45-153.

175 Cic. nat. deor. 2.27: Ov. met. 16.196-198; Serv. ad Aen. 4.511. Sobre estas cuestiones puede verse: C. Ampolo, «L’Artemide di Marsiglia e la Diana dell’Aventino», PP, 25, 1970, 200-210; M.J. Pena, «Artemis-Diana y algunas cuestiones en relación con su iconografía y su culto en Occidente», Ampurias, 35, 1973, 109-134.

176 H. Jeanmaire, Couroi et courètes, Lille, 1939, 259; Piccirilli, «Artemide e la metis di Themistocle», 145 . 
del $\operatorname{mar}^{177}$. Resulta verdaderamente significativo el hecho de que la fiesta de Ártemis Muniquia tenga lugar en el mes en el que debía abrirse la temporada naviera corta -la que comienza hacia el mes de mayo ${ }^{178}$ - por lo que no sería extraño que se insertase en este entramado de celebraciones destinadas a sancionar y oficializar las operaciones marítimas. F. de Polignac ya apuntó que algunos de los rituales celebrados en los lugares costeros del Ática donde se veneraba a Ártemis -Braurón y Muniquia- podrían relacionarse con la apertura de la estación navegable ${ }^{179}$. Ninguno de los documentos alusivos a esta festividad en relación con prácticas náuticas como la celebración de regatas es anterior al siglo II a.C.; sin embargo, y dado que, como ya se ha señalado, el santuario de Ártemis Muniquia se remonta al siglo X a.C. y que la faceta marina de la diosa es evidente, es posible considerar que esta divinidad gozó, y no sólo en el Ática, de una importante consideración en las celebraciones asociadas a las prácticas náuticas y más concretamente al inicio de la temporada naviera. Además, fiestas similares a las de Ártemis Muniquia se dieron en otros lugares de $\mathrm{Grecia}^{180} \tan$ asociados a la navegación como Tórico, en cuyo calendario aparece una ofrenda a Ártemis Muniquia en Muniquión probablemente conectada con la fiesta Muniquia ${ }^{181}$.

Así pues, no creo que el carácter "marinero" de la fiesta se desarrolle a partir de la victoria de Salamina sino más bien al contrario. Dado que Ártemis se asociaba al mar en Muniquia desde una época muy antigua, los atenienses le atribuyeron su favor en una victoria naval. Y no sólo eso, asimismo, decidieron recordar esta "magna” hazaña el día en el que se celebraba una fiesta vinculada desde antiguo a la navegación y, además, a la guerra -por el carácter militar de la diosa- en el mar. Tal vez también, como decía a propósito de las Cibernesias, su origen pueda remontarse a un momento en que los aristócratas practicaban todas las actividades relacionadas con la navegación, entre ellas la guerra y la piratería, de ahí la conjunción del carácter militar y marino de Ártemis.

177 La fille d'Athènes. Le religion des filles à Athènes à l'époque classique: mythes, cultes et société, París, 1987, 188 .

178 Como señalaba en la nota 69, existen dos concepciones de la estación navegable, una corta, de mayo a septiembre, y una larga, de principios de marzo a noviembre.

I79 F. de Polignac, «Mediation, Competition, and Sovereignty: The evolution of rural sanctuaries in Geometric Greece», en Alcock, Osborne (Eds.) Placing the Gods..., 6.

I80 Calame, Thésée et l'imaginaire athénien..., 117-122, 190-204.

I8I Daux, «Le calendrier de Thorikos...», I50-174, 1. 40; Lupu, Greek Sacred Law..., 1. 40-46, p. I 43. Lupu cita un estudio sobre el santuario de Ártemis Muniquia que no me ha sido posible consultar:

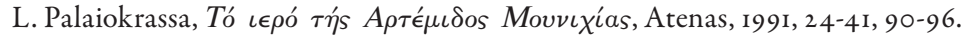




\section{II.2. Fiestas con baños de estatuas}

Encontramos en el mundo religioso de la Grecia antigua algunas festividades en las que la ceremonia más importante es una procesión donde se transporta la imagen de una divinidad hasta la costa para ser bañada en las aguas del mar. El baño purificador en el mar de una estatua divina se dio en varios lugares de la geografía griega. En Ifigenia en Táuride (IO39-IO4I, I193-I199) Eurípides menciona el baño purificador en el mar de la estatua de Ártemis (cf. Hyg. fab. I20.4), algo que debía realizarse en el ritual desarrollado en torno al culto de Ártemis Daitis en Éfeso, divinidad de las aguas, las fuentes, los lagos y protectora en el mar, corroborado por la existencia de unas sacerdotisas encargadas del baño de la diosa ${ }^{182}$.

El agua de mar tenía, por tanto, cualidades catárticas y purificadoras ${ }^{183}$ y era sagrada porque se le otorgó la capacidad de divinizar. Humanos como Britomartis, Ino, Melicertes, Glauco o las sirenas Parténope, Molpe y Leucosia ${ }^{184}$ alcanzaron el estatus divino gracias al katapontismos, su precipitación al mar, y se convirtieron en deidades muy próximas a las creencias populares de los marineros. Melicertes-Palemón, por ejemplo, tuvo gran importancia en Corinto en relación con la actividad marítima, pues el dios protegía a los navegantes ${ }^{18}$. Según la tradición, Ino se había arrojado al mar con su hijo Melicertes, el cual fue llevado hasta la costa por un delfín. Sísifo lo encontró, le dio sepultura e instituyó en su honor los Juegos Ístmicos ${ }^{186}$. De estos juegos no tenemos

I82 Ch. Picard, Éphèse et Claros. Recherches sur les sanctuaires et les cultes de l'Ionie du Nord, París 1922, 315-317 (también se conocía un culto de Afrodita Daitis); C. Calame, Les chours de jeunes filles en Grèce archaïque I, Roma, 1977, 180-181; L. Kahil, «Bains de statues et de divinités», en R. Ginouvès, A.M. Guimier-Sorbets, J. Jouanna, L. Villard (Eds.), L'eau, la santé et la maladie dans le monde grec (BCH suppl. 28), París, 1994, 220-221. Cf. X.Eph. I.2.2 ss.; EM. s.v. $\Delta$ aı тís; CIG II.3657.

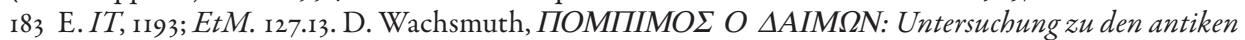
Sakralhandlungen bei Seereisen, Diss., Berlín, 1967, 218 ss.; A. Zografou, «Élimination rituelle et sacrifice en Grèce Ancienne» en S. Georgoudi, R. Koch Piettre, D. Schmidt (dirs.), La cuisine et l'autel. Les sacrifices en questions dans les sociétés de la Méditerranée ancienne, Turnhout, 2005, 199-200.

I84 Romero Recio, Cultos marítimos..., I 4, 20, 67-68, 74 ss., 83 ss., 104, I23, I 40, I53 (se citan las fuentes y la bibliografía específica); «El espacio marino como depósito de las manifestaciones divinas», ARYS, 5, 2002, 39-46. Véase más recientemente, sobre las precipitaciones en general: R. Koch Piettre, «Précipitations sacrificielles en Grèce Ancienne» en Georgoudi, Koch Piettre, Schmidt (dirs.), La cuisine et l'autel..., 77-100.

185 E. IT, 270-27I; Paus. I.44.7-8; 2.I.3; 2.I; Pi. fr. 5 Bowra; Philostr. Im. 2.16; Plu. Thes. 25.2; Hyg. fab. 2; Ael. Aristid. Isthm. 46, 40-4I Keil; Zen. 4.38; Clem. Al. Protr. 2.34.I; schol. Pi. I. 349.

186 Ov. met. 4.506-542; fast. 6.485; Apollod. bibl. 1.9.1 ss.; 3.3.28-29; Plu. Thes. 25.2; QR. 16; Paus. I.44.7-8; 2.I.3; 8.48.2; Apul. met. 4.31; Lucian. DMar. 8; Stat. Theb. 1.12I-I22; Hyg.fab. 2, 4; Zen. 4.38; Clem. Al. Protr. 2.34.I; Philostr. Im. 2.16; Serv. ad Aen. 5.241; schol. Od. 5.334; schol. E. Med. 1274; schol. A.R. 3.1320. 
constancia hasta el año 580 a.C. y sabemos que se celebraban en primavera, al contrario de lo que sucede con los restantes juegos panhelénicos que tenían lugar en verano, lo cual invita a pensar que tal vez pudiesen asociarse al inicio de la temporada naviera dado su nacimiento en relación con una salvación en el mar y un culto costero. En honor de Palemón se levantó además un santuario (Paus. 2.2.I) datado en el s. IX a.C. o incluso antes, se celebraban unas ceremonias secretas nocturnas (Ael. Aristid. Isthm. 46, 40-4I Keil), de las cuales se sabe que se sacrificaba un toro negro (Philostr. Im. 2.I6), que los participantes vestían una indumentaria específica, que se recitaban himnos que recordaban las vicisitudes del dios (Philostr. Her. 52.3-53, 4) ${ }^{187}$ y que probablemente se celebraban regatas ${ }^{188}$. En Ténedos existía un culto de Palemón, tal vez similar al corintio, al que se asociaba el sacrificio de niños ${ }^{189}$. Asociado al espacio sacro dedicado a Palemón se han encontrado numerosas lámparas que debieron ser empleadas en estas ceremonias nocturnas probablemente realizadas en el Áditon, la cripta donde se decía que descansaba el cuerpo del dios ${ }^{190}$.

Precisamente creo que la capacidad que se atribuye al agua de mar de otorgar la divinidad -como habría sucedido con Palemón- es la que se subyace en las fiestas que se estudiarán en este apartado, pues el baño de las estatuas de estas diosas podía renovar sus poderes en un ámbito que, en principio, no les pertenecía. Asimismo, también los fieles que se estaban moviendo en un medio que les era ajeno, podrían renovar sus votos mediante unas celebraciones que recordarían a las divinidades la necesidad de velar por ellos.

I87 Cf. C. Bonnet, «Le culte de Leucothéa et de Mélicerte, en Grèce, au Proche-Orient et en Italie», SMSR, 52, 1986, 53-60; M. Piérart, «Panthéon et hellénisation dans la colonie romaine de Corinthe: la "redécouverte" du culte de Palaimon à l'Isthme», Kernos, II, 1998, 89 ss.; R.A. Seelinger, «The Dionysiac context of the cult of Melikertes/Palaimon at the Isthmian sanctuary of Poseidon», Maia, n.s. 50, 1998, 271-280; Romero Recio, Cultos maritimos..., I39-I40; E.R. Gebhard, «Caves and Cults at the Isthmian Sanctuary of Poseidon», en R. Hägg (ed.), Peloponnesian Sanctuaries and Cults. Proceedings of the Ninth International Symposium at the Swedish Institute at Athens, II-I3 june 1994, Estocolmo, 2002, 74.

188 Gardner, «Boat-Races among the Greeks», 92.

189 Bonnet, «Le culte de Leucothéa...», 60 .

190 Paus. 2.2.I. O. Broneer, «Excavations at Isthmia: Third Campaign, 1955-1956», Hesperia, 27, 1958, 87. Sobre la existencia de comidas tribales en honor de Palemón: E.R. Gebhard, «Caves and Cults at the Isthmian Sanctuary of Poseidon», en R. Hägg (ed.), Peloponnesian Sanctuaries and Cults. Proceedings of the Ninth International Symposium at the Swedish Institute at Athens, II-I3 june 1994, Estocolmo, 2002,74 . 
En el mes de Targelión (mayo/junio) -el día oscila entre el 24, el 25 y el $29^{191}$ - se celebraban en Atenas las Plinterias ${ }^{192}$. En esta festividad el xoanon de Atenea se bañaba en el mar y se vestía con nuevas ropas. Los miembros del genos de los Praxiergidai se llevaban los adornos de la imagen de Atenea Polias y celebraban unos ritos secretos.

La interpretación de las Plinterias ha traído consigo un amplio debate que fundamentalmente gira en torno a la posibilidad de que coincidiese con una procesión en la cual se trasladaba a Palas hasta Falero y que conocemos gracias a los decretos de los Efebos ${ }^{193}$. Burkert, considerando que se trata de dos celebraciones diferentes, defiende que la «Palas» trasladada es el Paladio y que la Procesión hasta el puerto celebraba la apertura del tribunal de justicia que tenía lugar en el mes de Maimacterión (noviembre/ diciembre) ${ }^{194}$. Sin embargo, como ha observado B. Nagy, el orden de las festividades en los decretos de los Efebos no se ajusta a una cronología invariable pues dependía de la popularidad de estas fiestas ${ }^{195}$. Así pues, no suponen un criterio indiscutible para ubicar temporalmente la celebración de una festividad. La autora cree, por otra parte, que existen argumentos suficientes que permiten pensar que el xoanon de Atenea fue llamado Palas, por lo que en la procesión de Falero no se trasladaría el Paladio, como sostiene Burkert, sino el antiguo xoanon de la diosa ${ }^{196}$. Ahora bien, Nagy opina que la Procesión no podía coincidir con las Plinterias, pues éstas eran unas fiestas consideradas nefastas y durante las cuales se suspendían las actividades de importancia; por tanto, no

191 Deubner, Attische Feste, i8 (día 29); Mikalson, The sacred and civil calendar..., 160-161 (día 25); J.M. Mansfield, The Robe of Athena and the Panathenaic "Peplos", diss. Berkeley, 1985, 37 I-378, 424-433 (día 24, p. 392, n. 4I).Parker, Polytheism and Society..., 478-479, n. 44 (día 25).

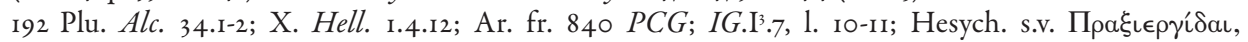

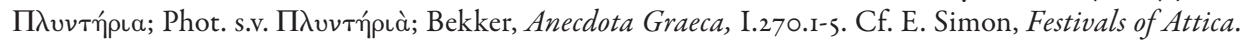
An Archaeological Commentary, Madison, 1983, 46-48; M. Christopoulos, «'ОРГІА АПОРРНТА': Quelques remarques sur les rites des Plyntéries», Kernos, 5, 1992, 35-36; Kahil, «Bains de statues...», 221-222; Parker, Athenian Religión..., 307-308; Robertson, «Athena and early Greek society...», 398 ss.; «Athena's shrines and festivals», en J. Neils (Ed.), Worshipping Athena. Panathenaia \& Parthenon, Wisconsin, 1996, 48-52; S. Scullion, «Three Notes on Attic Sacrificial Calendars», ZPE, I21, I998, I2O-I2I.

$193 I G . \mathrm{II}^{2} .1006$, l. II ss., 75 ss; 1008, 1. 9 ss.; I0II, l. Io ss. (se enmarcan cronológicamente entre el I22 y el I05 a.C. aproximadamente). B.D. Meritt, «Greek Inscriptions», Hesperia, 16, 1947, 170-172, n. 67, 1. 19. Cf. Schol. Dem. 23.71; Philoch. FGrH 328 F 64. A favor de la identificación: M.P. Nilsson Griechische Feste von religiöser Bedeutung, Stuttgart, 1957 ( $\mathrm{I}^{\mathrm{a}}$ ed. 1906), 102; Deubner, Attische Feste, $18 \mathrm{ss.}$

194 W. Burkert, «Buzyge und Palladion: Gewalt und Gericht in altgriechischen Ritual», $Z R G G, 22$, 1970, 356-368; Homo necans. The anthropology of ancient Greek sacrificial ritual and myth, Berkeley-Los Angeles-Londres, 1985 ( $\mathrm{r}^{\mathrm{a}}$ ed. 1972), 79 ss.

195 B. Nagy, «The Procession to Phaleron», Historia, 40.3, 1991, 290-294.

196 Nagy, «The Procession to Phaleron», 295 ss. Cf. Paus. I.26.6. 
parecían adecuadas para la intervención de los Efebos que participaban en festividades en las que podían poner de manifiesto sus aptitudes personales. La Procesión a Falero sería probablemente la conmemoración del regreso de la estatua de Atenea a la ciudad después de la evacuación de Atenas con la llegada de los persas ${ }^{197}$. Según Plutarco, el Gorgoneion de la diosa estuvo perdido, fue hallado en la playa y llevado a la ciudad por Temístocles.

La fiesta de las Plinterias se celebraba en distintos lugares de la geografía helena como en Tórico, y probablemente en Erquia, Tasos o Tegea, y se enmarca en el mismo tipo de ritual marcado por el baño de una estatua de Atenea ${ }^{198}$. En Tórico tenía lugar un mes después, en Esciroforión (junio/julio), probablemente porque se trataba de una celebración local que no podía coincidir con la fiesta ateniense ${ }^{199}$. Encontramos en el calendario de este demo junto a la ofrenda de una oveja escogida a Atenea en las Plinterias, la ofrenda del mismo animal a Aglauro. Asimismo, la etiología de la fiesta ateniense está vinculada a la cecrópide Aglauro en algunas fuentes ${ }^{200}$. Las versiones sobre las circunstancias de la muerte de esta princesa hija de Cécrope varían pero en todas acaba arrojándose desde la Acrópolis ${ }^{201}$. En una de ellas es la propia princesa la que se lanza voluntariamente para dar así cumplimiento al oráculo que establecía la victoria de los atenienses sobre los eleusinos si alguien ofrecía su vida por la ciudad. En recuerdo de esta hazaña, los Efebos celebraban su juramento en el santuario de Aglauro mencionando su nombre en primer lugar ${ }^{202}$.

Como ya he séñalado más arriba, Cécrope es un mítico rey del Ática al que se atribuye una primera organización del territorio con el establecimiento de doce poleis, entre ellas, Tórico, Braurón y posiblemente, Falero. La disputa entre Posidón y Atenea por el dominio de Atenas tendría lugar también durante el reinado de Cécrope que habría tomado partido a favor de la diosa ${ }^{203}$. En el Erecteo había un pozo de agua salada que Posidón había hecho brotar golpeando la roca con su tridente, cuando tuvo lugar

197 Plu. Them. Io; cf. Hdt. 8.4I; «The Procession to Phaleron», 302 ss.

198 N. Robertson, «The Riddle of the Arrhephoria at Athens», HSCPh, 87, 1983, 280-284.

199 Lupu, Greek Sacred Law..., 1. 52-53, p. 146. En otro calendario de origen incierto $\left(I G \mathrm{I}^{3} 246 \mathrm{C} 26\right)$ se constata también un sacrificio a Atenea en Targelión durante las Plinterias.

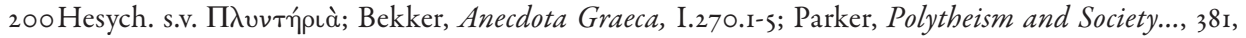
478.

201 Apollod. Bib. 3.14.2, 6; Eurip. Ion. 20 ss., Paus. I.2.6; Hyg. fab. 166; Ov. met. 2.560, 710 ss.

${ }_{202}$ Cf. Ch. Pélékidis, Histoire de l'éphébie Attique des origines à 31 avant Jésus Christ, París, 1962, II ss.; G.S. Dontas, «The True Aglaurion», Hesperia, 52.I, 1983, 48-63; J. Larson, Greek Heroine Cults, Madison-Londres, 1995, 39-40.

203 Apollod. Bib. 3.I 4.I ss.; Marm. Par. 1.2-4; Str. 9.1.20; Paus. 1.2.6, 5.3, 31.5; Hyg. Fab. 46; Euseb. Chr. I.184; Kearns, The Heroes of Attica, 80 ss. 
este enfrentamiento (Hdt. 8.55; Paus. I.26.5; Apollod. bibl. 3.I4.I). En éste se podía oír el rumor de las olas cuando soplaba el viento del sur y en la roca se veía la forma de un tridente (Paus. I.26.5). Cécrope tenía otras dos hijas además de Aglauro, Herse -o Curótrofa según las inscripciones- y Pándroso. Pándroso recibía culto en Atenas junto a Atenea y también a ambas estaba dedicada la fiesta de las Arreforias en el mes Esciroforión ${ }^{204}$.

Creo que todos estos datos refuerzan el carácter marino de las Plinterias por varias razones. En primer lugar, la diosa en torno a la cual gira la fiesta es Atenea, de quien ya hemos tenido ocasión de subrayar su importancia como diosa protectora de la navegación. En segundo lugar, la conexión de la fiesta con la cecrópide Aglauro, que a su vez se asocia a un juramento de los efebos, suaviza los obstáculos a la hora de admitir un nexo entre la procesión a Falero protagonizada por éstos y la celebración de la fiesta que culminaba con el baño de la diosa en el mar. En tercer lugar, todas las localidades del Ática que se relacionan con las Plinterias tienen varios elementos en común como la conexión con Aglauro y la antigüedad de los establecimientos corroborada tanto por las fuentes -la dodecápolis de Cécrope- como por la arqueología. En cuarto lugar, como he destacado a propósito de las Cibernesias, la celebración de fiestas y rituales con connotaciones náuticas en estos lugares está constatada desde una época muy antigua. Y por último, en Tórico las Plinterias se celebran un mes después que en Atenas, probablemente para no coincidir, pero aproximadamente cuando éstas están teniendo lugar en Targelión, en Tórico está constatado el sacrificio de una oveja en honor de un héroe de los navegantes, Sosineo, lo cual parece corroborar que estas fechas eran óptimas para la conmemoración de héroes y dioses de los navegantes. Kearns ya destacó que el culto de Sosineo debía ser lo suficientemente importante como para que se hubiese institucionalizado un safricio anual costeado, presumiblemente, por el demo y no dudaba de la existencia de otros cultos y celebraciones dedicados a héroes similares en los restantes demos costeros del Ática ${ }^{205}$.

Así pues, desde mi perspectiva, el ritual del baño del xoanon de Atenea en las Plinterias debe relacionarse tanto con la purificación de la estatua de Atenea, necesaria porque la diosa se había visto forzada a abandonar el espacio que le estaba consagrado, como con la renovación del carácter marino de la divinidad. De hecho, se observa una «natural» conexión del xoanon con el mar al aparecer el Gorgoneion de la diosa en la playa después de haber estado en paradero desconocido. Recordemos en este sentido las

\footnotetext{
204Apollod. Bib. 3.1 4.2 ss.; Paus. I.2.6, I8.2; Ovid. Met. 2.558 ss.; school. Il. 1.334; Burkert, Homo Necans, I50-I54; Robertson, «The Riddle of the Arrhephoria...», 24I-288; Simon, Festivals of Attica..., 39 ss. 205 Kearns, The Heroes of Attica, 37.
} 
consideraciones expuestas más arriba a propósito de la relación entre el coral y el color rojo y una Atenea con poderes en el mar ${ }^{206}$. Considerando la intervención de Atenea en la navegación, así como su patronazgo sobre la flota ateniense, no me parece peregrino plantear que también las Plinterias buscasen un reencuentro de la diosa con el mar. La constructora y guía de barcos necesitaría reforzar estas funciones a través del contacto con el elemento marino.

Y esa necesidad de renovar y reforzar anualmente los poderes en el mar creo que subyace también en otra fiesta, las Tonea, protagonizada por la Hera de Samos, pues es posible observar algunos elementos semejantes a los mencionados a propósito de las Plinterias. Como veremos a continuación, por distintas circunstancias, tanto la imagen de Hera en Samos como la de Atenea en la Acrópolis, se habían visto forzadas a abandonar el espacio que les estaba consagrado lo que exigía una purificación, el regreso de ambas se vinculaba a un hallazgo en la playa y también las dos protagonizaban un baño ritual con agua de mar.

Las Tonea tenían lugar a finales de julio en el «puerto de Hera». Durante esta fiesta, la imagen de la diosa se transportaba hasta la playa en procesión. Allí se lavaba

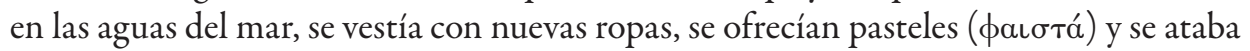
con las ramas del $\lambda$ úros.

Ateneo, siguiendo a Menodoto de Samos y a Nicaeneto ${ }^{207}$ cuenta que el ritual anual de las Tonea conmemoraba fielmente el retorno de la imagen de la diosa a Samos. El autor relaciona, por tanto, esta festividad con un acontecimiento que vincula a la diosa, indefectiblemente, con el $\operatorname{mar}^{208}$. Los argivos habían encargado a unos piratas tirrenos que robasen la imagen de la diosa (el $\beta \rho \in ́$ тas) para llevarla después a Argos. Prodigiosamente, Hera paralizó la nave y obligó a la tripulación a regresar a Samos donde los piratas la dejaron sobre la playa ofreciéndola pasteles ( $\psi a \iota \sigma \tau \alpha ́$ ) antes de partir. Los carios, creyendo que ésta se había marchado voluntariamente, ataron la imagen con las ramas del lygos (la mimbrera). Apolo ordenó a los carios que debían realizar las coronas sólo con el mismo tipo de ramas con las que habían atado a la diosa (Ath. 15.672 e-673b). Por su parte, Pausanias (7.4.4) recoge otras dos tradiciones. La primera de ellas decía que el santuario de Hera en Samos fue fundado por los Argonautas y fueron ellos quienes llevaron en su nave la imagen de Argos. La segunda, de carácter local,

206 El color del coral tendría su origen en la sangre de la Gorgona que habría llegado al mar cuando Perseo se lavó en sus aguas.

207 Ath. 15.672 d-e, 673 b-c.

208 Ath. 15.672 a-d. 
consideraba que la diosa había nacido en la isla, al pie de la mimbrera que aún podía contemplarse en época de Pausanias en el Hereo. La existencia de una moneda de época de Gordiano III (s. III) en la que se representa el santuario de Hera con un árbol ha invitado a pensar que el lygos todavía se vinculaba al culto de la diosa en esta época ${ }^{209}$. Sin embargo, la arqueología no ha corroborado aún con más datos la existencia de este árbol dentro o cerca del templo ${ }^{210}$.

En una zona pantanosa situada entre el altar y el mar, a donde llegaban los peregrinos que habían hecho el viaje en barco antes de que se construyese la vía sagrada que unía la ciudad con el santuario, se encontraron, junto con otros objetos, unos cuarenta modelos de naves de madera que habían sido ofrecidos como exvotos desde finales del siglo VII a.C. ${ }^{211}$. Tomando como referencia los canastillos en forma de nave que se emplean en las celebraciones de la Madonna del Granato -herederas de los antiguos rituales celebrados en el Hereo del Sele-, algunos investigadores han supuesto que los modelos de barcos hallados en el santuario se usaban también durante la procesión de las Tonea ${ }^{212}$, pues además en la Argólida han aparecido estatuas de terracota que representaban a la diosa llevando una barquita llena de flores ${ }^{213}$. P. Zancani Montuoro y U. Zanotti Bianco ya señalaron hace tiempo que la procesión y el culto de la Madonna del Granato eran herederos del culto de Hera ${ }^{214}$. También estableció esta vinculación A. Rossi, aunque pensando en una antigua ceremonia de carácter fúnebre relacionada con la fertilidad ${ }^{215}$. En cualquier caso, y como ya apunté en la introducción, creo que el hecho de que se trate de fiestas asociadas a la fertilidad no impide que lo sean también de la navegación. He tenido ya ocasión de indicar algunos ejemplos como la simbiosis de aspectos que se produce en el espacio sacro consagrado a Afrodita Colíade pero, más

209 H. Walter, Das Heraion von Samos, Munich, 1976, 108 ss.

2 I0 H.J. Kienast, «Zum heiligen Baum der Hera auf Samos», $A M$, 106, 1991, 75 ss.

21 G. Kopcke, «Neue Holzfunde aus dem Heraion von Samos», $M D A I(A), 82$, 1967, 145-1 48, pl. 82-83; H. Kyrieleis, «Archaische Holzfunde aus Samos», $M D A I(A)$, 95, 1980, 89-94, pl. 18-20; «The Heraion at Samos», en Hägg, Marinatos (eds.), Greek Sanctuaries...I4I-I43; Johnston, Ship and boat models..., 54-64, n. 3-24. Sobre este tipo de ofrenda: Romero Recio, Cultos maritimos..., 5 ss. J.D. Baumbach (The Significance of Votive Offerings in Selected Hera Sanctuaries in the Peloponnese, Ionia and Western Greece, Oxford, 2004, 163) sigue en líneas generales -e ignorando prácticamente toda la bibliografía que no sea alemana e inglesa- las interpretaciones tradicionales y relaciona la ofrenda de barcos con la pesca y con la armada.

2I2 Kyrieleis, «Archaische Holzfunde aus Samos», 89-94; «The Heraion at Samos», I 43.

213 A. Frickenhaus, «Die Hera von Tiryns», en: Tiryns I, Atenas, 1912, 63, I2 4 ss., taf. III.8.

2 I 4 Heraion alla foce del Sele, II, Roma, 1954, 19, n. 2.

215 «Tracce di continuità culturale fra paganesimo e cristianesimo: le offerte votive», en E. Di Simoni, (Ed.), Ex voto tra storia e antropologia, Roma, 1986, 30. 
concretamente en el ámbito de las fiestas religiosas, resulta verdaderamente significativa la descripción realizada por Apuleyo (met. ir.7) en los momentos previos al comienzo de la celebración del Navigium Isidis, una de las festividades más innegablemente marinas, incidiendo en la regeneración y en la fecundidad vegetal y animal. «El mundo entero» dice «me parecía rebosar felicidad: toda clase de animales, todas las familias y hasta el aire que se respiraba me daban una impresión de paz y satisfacción... Hasta los árboles tanto los fecundos frutales como los que se conforman con darnos el producto estéril de su sombra, todos se desarrollaban al soplo del Austro, se engalanaban con los brotes de nuevos pimpollos y susurraban leves murmullos moviendo suavemente sus brazos. Había cesado el rudo fragor de las tormentas, el mar había calmado la furia turbulenta de su oleaje y besaba la arena en suave ondulación» (trad. L. Rubio Fernández, BCG, Madrid, 1987) ${ }^{216}$.

Normalmente se ha asociado el lygos a la castidad, y teniendo en cuenta que los argivos también lavaban a Hera una vez al año con el fin de que recobrase su virginidad (Paus. 2.38.2), se ha considerado que el baño ritual de Hera en Samos se realizaba con el mismo fin ${ }^{217}$. Se trataría de una purificación que se exigía después del sacrilegio que habían protagonizado los carios. Asimismo, en muchas ocasiones se identifica a las Heraia con esta fiesta otorgándole una relación con la sexualidad y la fecun$\operatorname{didad}^{218}$, incluso con los excesos sexuales, de ahí la necesidad de amarrar a la diosa con la mimbrera ${ }^{219}$. Por otra parte, también se ha señalado que el rito de las Tonea estuvo destinado a renovar el orden después de un estado de urgencia ${ }^{220}$.

No creo que se pueda equiparar el baño de las Tonea con el de Hera argiva, pues para empezar ésta no se lavaba en el mar, sino en una fuente llamada Cánato. Como ya he señalado, el baño purificador en el mar de una estatua divina se daba en otros lugares como en Éfeso y Atenas. Desde mi perspectiva, estas purificaciones de las imágenes de divinidades tan vinculadas al medio como Hera, Atenea y Ártemis no han de ser únicamente rituales para propiciar la fertilidad -si bien es un aspecto, repito, que tampoco veo en absoluto incompatible con el ámbito marino-, sino que deben tener una

216 Esta asociación de la fiesta con la fertilidad animal y vegetal ha sido señalada por Dunand, Le culte d'Isis..., III, 228.

217 E. Buschor, «Heraion von Samos: Frühe Bauten», $A M$, 55, 1930, 2.

218 A.M. Cirio, «La Dea Parthenos di Samo», BollClass, ser. 3, 2, 1981, I36-1 42; M. Nafissi, «Anacreonte, i Tonea e la corona di $L y g o s », P P, 38,1983$, n. 24 ss., con una exhaustiva recopilación bibliográfica sobre el tema.

219 G. Kipp, «Zum Hera-Kult auf Samos», en Kritische und vergleichende Studien zur Alten Geschichte und Universalgeschichte. Innsbrucker Beiträge zur Kulturwissenschaft, 18, 1974, 204-208.

220 K. Meuli, Gesammelte Schriften, Basel, 1975, 1034-1081. 
conexión con el espacio religioso de los navegantes. De hecho, incluso en la actualidad se realiza en algunos lugares una bendición de las aguas del mar mediante la inmersión de una estatua de la Virgen o de un santo protector de los navegantes ${ }^{221}$. Es más, la fiesta de la Virgen del Carmen, patrona de los marineros a la que se invoca para que salve a los barcos de los naufragios, se celebra el 16 de julio con procesiones marítimas en las zonas costeras y también a la Virgen bajo esta advocación solían dirigirse las muchachas casaderas, por ejemplo en Cataluña, para pedirle marido. Creo que la simbiosis de estas dos funciones -protectora de la navegación y de los matrimonios- se da también sin dificultad en el caso de la diosa Hera en la antigüedad griega.

Parece aceptable que el baño de la diosa se considere un ritual de purificación, en este caso por el sacrilegio cometido, e incluso resulta sugerente que, como sostiene M. Nafissi, la castidad cultual que se impone a los carios con la corona del lygos, sea un signo de la consagración de éstos a la diosa, es decir, como hieroi o hierodouloi $i^{222}$. Sin embargo, creo que estas teorías no alcanzan a explicar el verdadero significado de las Tonea. En mi opinión, esta festividad que conmemoraba el retorno de Hera a Samos puede encontrar su sentido en el marco de las celebraciones vinculadas a la piedad de los navegantes, en primer lugar, porque sería lógico encontrar un fiesta asociada a la navegación en un santuario demostradamente vinculado a la actividad náutica, y en segundo lugar, por las connotaciones "marinas" de la fiesta y la mitología asociada a ella y a la propia diosa. Veamos estos aspectos con algo más de detenimiento.

Durante el s. VII Samos ya va a destacar por sus actividades marítimas que la llevarán hasta puntos muy alejados del Mediterráneo como Tarteso, tal y como cuenta Heródoto (4.152) a propósito de la aventura de Coleo de Samos quien, por cierto, entrega a la diosa la décima parte de sus beneficios al regresar de su viaje ${ }^{223}$. También será una de las doce ciudades griegas que se asentarán en Náucratis durante el siglo VI,

221 M. Mollat, «Les attitudes des gens de mer devant le danger et devant la mort», Ethnologie Française, n.s. 9, 1979, 195. Svoronos menciona algunas fiestas y rituales de época contemporánea donde todavía se seguía dando esta costumbre: «Stylides, Ancres hierae, Aphlasta, Stoloi, Ackrostolia, Embola, Proembola et Totems marins», Journal International d'archéologie numismatique, 16, 1914, 105 ss.; Romero Recio, Cultos maritimos..., 58-59.

222 Nafissi, «Anacreonte, i Tonea...», 428.

223 En el santuario de Hera en Samos aparecieron unos peines de marfil grabados, ajenos al ámbito egeo pero con paralelos exactos en unos marfiles fenicios hallados en el valle del Guadalquivir: B. Freyer Schauenburg, «Kolaios un die westphönizischen Elfenbeine», $\operatorname{MDAI}(M)$, 7, 1966, 89-108. 
gracias a una concesión del faraón Amasis, aunque probablemente estaría establecida en la zona desde época anterior ${ }^{224}$.

El Hereo de Samos estuvo asociado a las actividades marítimas desde un momento muy antiguo. Existen indicios de un culto ya desde la segunda mitad del segundo milenio a.C. en el lugar donde posteriormente se levantará el templo de Hera. El primer altar data del siglo X y durante el período arcaico aparecen numerosas ofrendas que vinculan a Hera con la religiosidad de los navegantes como los modelos de barcos que hemos mencionado e incluso naves auténticas ${ }^{225}$. Antes de la construcción de la vía sagrada, los peregrinos que acudían a Samos arribaban directamente por mar hasta el santuario. En esta zona los arqueólogos han encontrado tres pozos que sin duda sirvieron para suministrar agua potable a los devotos y viajeros. El gran templo se construyó hacia el 522 a.C., pero cuando Samos quedó integrada en la liga de Delos (480-479) cesaron las construcciones y comenzaron a llegar colonos atenienses que confiscaron ricas tierras en torno al santuario (aparecen horoi dedicados a Atenea). Es el momento en el que Hera es reemplazada por Atenea en su propio recinto como se observa al comprobar una sensible disminución de las ofrendas privadas, un abandono de la vajilla ritual tradicional y una importancia creciente de los agones deportivos durante la gran fiesta de $\mathrm{Hera}^{226}$. Sin embargo, Atenea es también la protectora de

224 Hdt. 2.178; C. Roebuck, «The organization of Naucratis», $C P h$, 46,195I, 21I-220; G. Shippley, $A$ History of Samos, 800-188 B.C., Oxford, 1987, 56 ss.; H. Bowden, «The Greek Settlement and Sanctuaries at Naukratis: Herodotus and Archaeology», en M.H. Hansen, K. Raaflaub (eds.), More Studies in the Ancient Greek Polis. Papers from the Copenhagen Polis Centre, 3, 1996, 17-37; Domínguez Monedero, «La Religión en el emporion», 24I-243. Más concretamente sobre Náucratis: A. Möller, Naukratis. Trade in Archaic Greece, Oxford, 2000; U. Höckmann, D. Kreikenbom (eds.), Naukratis. Die Beziehungen zu Ostgriechenland, Ägypten und Zypern in archaischer Zeit. Akten der Table Ronde in Mainz, 25-27 Nov. 1999, 2001. Sobre las ofrendas realizadas por gobernantes extranjeros, también egipcios, en santuarios griegos: Ph. Kaplan, «Dedications to Greek Sanctuaries by Foreign Kings in the Eighth through Sixth centuries BCE», Historia. Zeitschrift für Alte Geschichte, 55.2, 2006, 129-152.

225 H. Kyrieleis, Führer durch das Heraion von Samos, Atenas, 1981, I6 ss.; H. Walter, Das griechische Heiligtum dargestellt am Heraion von Samos, Stuttgart, 1990, 83, fig. 92, 89, fig. 98; Ph. Brize, «Offrandes de l'époque géométrique et archaïque à l'Héraion de Samos», en J. de La Genière (Ed.), Héra. Images, espaces, cultes. Actes du Colloque International de Lille 1993, Cahiers du Centre Jean Bérard i5, Nápoles, 1997, 130; Romero Recio, Cultos maritimos..., 4-5.

226 U. Kron, «Kultmahle im Heraion von Samos archaischer Zeit. Versuch einer Rekonstruktion», en Hägg, Marinatos, Nordquist (Eds.) Early Greek Cult Practice..., I35-148; A. Furtwängler, «L'Heraion de Samos: quelques aspects de l'évolution du sanctuaire du $V^{\mathrm{e}}$ siècle à l'époque hellénistique. Essai d'interprétation», en La Genière (ed.), Héra. Images, espaces..., I42. 
los navegantes por lo que no debió de producirse un cambio radical en los ámbitos de actuación de la divinidad tutelar del santuario de Samos.

Pero el de Samos no fue el único santuario donde Hera se asoció a la religiosidad de los navegantes. Los de cabo Lacinio en Crotona o el de Perácora constituyen buenos ejemplos, además de otros santuarios costeros en los que la diosa aparece con epítetos como Acrea, Limenia o Epilimenia ${ }^{227}$.

Por otra parte, como decía, la vinculación mitológica de la diosa con el mar no debe ser pasada por alto pues Hera también -criada según una tradición por Océano y Tetis- llega en barco en una versión que hacía de los Argonautas los fundadores del santuario samio (Paus. 7.4.4). Además, como ha apuntado Ph. Brize, la Hera samia guarda interesantes similitudes con Hécate, la diosa más importante de Caria, y en el Himno a Hécate, que se integra en la Teogonía de Hesíodo (vv. 4II-452), se atribuye a la divinidad una función naval, además de política, militar y agonal ${ }^{228}$. Y no es este el único lugar, como he tenido ocasión de destacar más arriba, donde se observan los nexos de Hécate con el mar y la navegación.

Mediante una procesión ritual que unía el santuario con el litoral, durante las Tonea se purificaría con agua marina la estatua de Hera de la profanación de los piratas y de los sacerdotes, pero también se renovaría el control que la diosa ejercía en el mar, control que había practicado al paralizar el barco de sus raptores y que también había puesto de manifiesto ayudando durante la travesía a la nave Argo, la cual debía llevar su imagen a Samos ${ }^{229}$. Del mismo modo que el katapontismos diviniza pero limita el ámbito de actuación de los «nuevos dioses» al medio marino, el contacto, en este caso de Hera, con el mar, rehabilitaría anualmente el poder de la diosa en este espacio. Las ofrendas que se realizaban durante las Tonea, los pasteles, eran las mismas que presentaron los piratas para paliar el acto de impiedad, pero también para agradecer a la diosa que no hubiese provocado su muerte en el mar. Igualmente, cuando los fieles ofrecían los pasteles durante la fiesta samia podían estar agradeciendo a Hera su ayuda en la navegación, así como solicitando su futuro auxilio. Desde esta perspectiva, parece posible que en el mismo contexto se hubiesen podido consagrar algunos de los modelos votivos de barcos. Esta ofrenda podría completar el acto de renovación ritual con una expresión de fiel reconocimiento a las facultades de la diosa anualmente reavivadas.

227 Sobre el papel de Hera como diosa asociada a la navegación y sus lugares de culto: Romero Recio, Cultos maritimos..., 38 ss., 5 I ss., I2I, I35 ss., I52 ss.

228 Brize, «Offrandes de l'époque géométrique...», 137.

229 A.R. 2.216-217, 865 ss.; Apollod. bibl. 1.9.22; Val. Flac. 4.682 ss.; Hyg. fab. 19.4. 


\section{II.3. Fiestas con procesiones de dioses a bordo de barcos}

El calendario litúrgico griego incluye algunas fiestas en las que las divinidades conmemoradas son paseadas en procesión por la ciudad a bordo de barcos. Aunque algunos autores han minimizado este hecho o han buscado una explicación al mismo alejada del ámbito náutico, creo que los datos con los que contamos permiten establecer una relación entre estas festividades y la actividad marítima.

Una de estas fiestas a las que hago referencia son las Antesterias. Celebradas en el mes de Antesterión (febrero/marzo), entre los días ir y I3, incluían una procesión del dios Dioniso sobre un barco. El primer día tenía lugar la fiesta de las Jarras, las Pithoigia, durante la cual se abrían los recipientes que contenían el vino nuevo, pero antes de que pudiese ser degustado se realizaban libaciones. Al día siguiente (Choes) se hacía una prueba que consistía en beber lo más rápidamente posible el vaso de vino, y a continuación tenía lugar la procesión en la que aparecía Dioniso sobre el barco ${ }^{230}$. Después se desarrollaba una ceremonia secreta en presencia de la Basilina que pasaba a ser considerada la esposa del dios. La hierogamia se celebraba en la residencia del arconte, pero después llegaba un día nefasto (Chytroi) en el que las almas de los muertos subían desde los infiernos ${ }^{231}$.

La celebración de esta fiesta está constatada en Atenas, Cícico, Dídima, Tasos, Esmirna, probablemente en casi todas las ciudades jonias ${ }^{232}$ y tiene ecos en otras celebraciones locales como en Tórico, donde el día iz del mismo mes se sacrificaba en honor de Dioniso una cabra ${ }^{233}$.

El mito de Dioniso abunda en episodios que relacionan al dios con el mar y los viajes. Su nacimiento aparece ya asociado a la navegación. Viajó con su madre, Sémele, encerrado en un arca que llegó hasta Brasias (Paus. 3.24.3-4). Allí se podía ver, según

230 Un barco con ruedas o en un carro, cf.: Philostr. 1.25; Asistid., Rhet. 1.38; M. Guarducci, «Dioniso sul carro navale», NAC, I2, 1983, 107-118; H.A. Shapiro, Art and Cult under the Tyrants in Athens, Mainz, 1989, 99; C. Sourvinou-Inwood, Tragedy and Athenian Religion, Lanham, 2003.

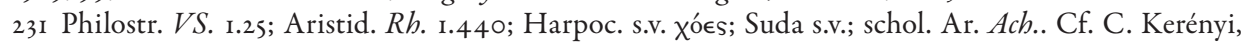
Dionysos. Archetipal image of indestructible life, Londres, 1976, 166 ss.; M. Guarducci, «Dioniso primaverile ad Atene», $N A C$, 9, 1980, 37-62; «Dioniso e il loto», $N A C$, 10, 1981, 53-69; «Dioniso sposo della regina», $N A C$, II, 1982, 33-46; R. Hamilton, Anthesteria and Choes: Athenian Iconography and Ritual, Ann Arbor 1992, 57; N.R.E. Fisher, «Multiples Personalities and Dionysiac Festivals: Dicaeopolis in Aristophanes' "Acharnians"», Greece \& Rome, 40.1., 1993, 31-47; Humphreys, The Strangeness of Gods..., 223 ss.; Parker, Polytheism and Society..., 290 ss.

232 Simon, Festivals of Attica, 93; Burkert, Homo necans, 199; F. Graf, Nordionische Kulte, Roma 1985, 387; C. Trümpy, Untersuchungen zu den altgriechsichen Monatsnamen und Monatsfolgen, Heidelberg, 1997; Humphreys, The Strangeness of Gods..., 226-227.

233 Aparece en el calendario de Tórico, 1. 33; cf. Lupu, Greek Sacred Law..., I22, 139. 
Pausanias, la cueva donde Ino le había criado. En Brasias había bronces que representaban a los Dioscuros o a los Coribantes y a Atenea, y además un santuario de Asclepio y de Aquiles (Paus. 3.24.5).

Por otra parte, recorre Grecia y Oriente, y acude a la corte de Proteo -dios marino mutante que habita en la isla de Faro y a quien Menelao consulta su futuro y el de sus compañeros gracias a la ayuda de Idótea ${ }^{234}$ y también protagoniza un katapontismos que le coloca bajo la protección de Tetis ${ }^{235}$. En Hermipo (ap. Ath. I.27e) aparece como un dios navegante que transporta en su barco los bienes procedentes de todos los rincones del mundo: las velas y los papiros de Egipto, el pescado salado del Helesponto y la carne de buey de Tesalia, entre otros. Su carácter marino y viajero tiene un punto culminante en su aventura con los piratas tirrenos, un delicioso episodio que presenta al dios en su doble vertiente, como navegante y marino en la línea de los prodigios que más debieron deleitar a los navegantes y como dios del vino y la regeneración vegetal ${ }^{236}$. Según esta tradición, Dioniso fue secuestrado por unos piratas tirrenos -como la Hera de Samos o el poeta Arión ${ }^{237}$. Cuando éstos se dieron cuenta del error cometido comenzaron a brotar viñas y racimos del mástil del barco y el dios se transformó en león. Los aterrorizados piratas saltaron de la nave y se convirtieron en delfines. Sin duda este mito condicionó que la aparición de este dios en sueños pronosticase tanto a los que viajaban por tierra como por mar, ataques de piratas, heridas y mutilaciones ${ }^{238}$.

Las representaciones artísticas apuntan en el mismo sentido, pues los vasos frecuentemente muestran a Dioniso tumbado sobre un barco y rodeado de elementos

234 Hom. Od. 4.349 ss. Cf. Apollod. bibl. 2.5.9; E. Hel. 6 ss.; Hdt. 2.112-117; D.S. 1.62; Verg. Georg. 4. 837 ss.; Ov. met. 11.224 ss.; Conon, 8.32; Serv. ad Aen. 1.651.

235 Hom. Il. 6.132-137; D.S. 3.65.4 ss.; Apollod. bibl. 3.5.I.

236 Hym. h. Dion. 7; Apollod. bibl. 3.5.3; Ov. met. 3.58I-686; Sen. Oed. 449-466; Hyg. fab. 134.2. Cf. entre otros: E.B. Stebbins, The dolphin in the literature and art of Greece and Rome, Wisconsin, 1929, 61, 72-73; A.W. James, «Dionysus and the Tyrrhenian pirates», Antichthon, 9, 1975, 17-34; M. Gras, «La piraterie tyrrhénienne en mer Égée: mythe ou réalité?», en Mélanges offerts à Jacques Heurgon I, L'Italie préromaine et la Rome Républicaine, Roma, 1976, 342-343; M. Giuffrida Ientile, La pirateria tirrenica. Momenti e fortuna, Roma, I983, 30 ss.; P. Somville, «Le dauphin dans la religion grecque», $R H R, 201$, 1984, 3-24. La escena se representó en algunas cerámicas y éstas han sido estudiadas por: N.J. Spivey, T. Rasmussen, «Dioniso e i pirati nel Toledo Museum of Art», Prospettiva, 44, 1986, 2-8; M. Harari, «Dioniso, i pirati, i delfini», en T. Hackens (Ed.), Navies and Commerce of the Greeks, the Carthaginians and the Etruscans in the Tyrrhenian Sea. Proceedings of the European Symposium held at Ravello, January, 1987, Estrasburgo-Ravello, 1988, 33-45.

237 Hdt.I.23-24; Stebbins, The dolphin in the literature..., 67.

238 Artem. Onir., 2.37. 
que aluden a la vegetación y al vino ${ }^{239}$. Unidos estos datos a la expresión de Hermipo, que señala que Dioniso conduce las naves por el mar color de vino, y al hecho de que muchas copas tuviesen nombres de barcos (trieres, gaulos, akatos...), han permitido pensar que Dioniso efectivamente fue venerado como una divinidad agraria y marina ${ }^{240}$. Se ha sugerido, incluso, a partir de representaciones de este tipo en vasos probablemente pintados en Egipto, que este ritual de las Antesterias pudo tener su origen en el uso de barcos en ceremonias nilóticas dedicadas a Osiris, Hator y Horus ${ }^{241}$.

Por otra parte, Dioniso fue también considerado un dios del más allá que a través de las aguas entraba en contacto con los difuntos ${ }^{242}$. En Naxos, por ejemplo, lleva el epíteto Miliquio ${ }^{243}$ que también es aplicado a Zeus como divinidad ctónica en la que, como ya he defendido en otro lugar, confluyen las cualidades propias de una deidad del mundo funerario que además es venerada por los navegantes que muestran su veneración dedicándole anclas ${ }^{244}$.

Dioniso recibe además epítetos como Pelagio, Aktaios, Limnaios, Limnagenés y Halieus ${ }^{245}$ y en sus iniciaciones está presente el agua de mar, pues durante las orgías de Dioniso que se celebraban en Tanagra las mujeres se purificaban bañándose en la playa $^{246}$. Según el mito, Dioniso salvó a estas mujeres de un ataque de Tritón -dios marino hijo de Posidón y Anfítrite- cuando estaban celebrando este ritual ${ }^{247}$.

Sin embargo, creo que en las Antesterias aparecen reflejados todos los ámbitos en los que se manifiesta Dioniso: divinidad agraria que trae el vino, deidad de los

239 J.D. Beazley, Attic Black Figure Vase Painters, Oxford, 1956, 146, 21; 639, 100.

240 M. Daraki, «La mer dionysiaque», RHR 199, 1982, 3-22; Dionysos, París, 1985, 41-42.

24I Guarducci, «Dioniso sul carro navale», I07-I18; Mansfield, The Robe of Athena..., I21-130. Cf. Humphreys, The Strangeness of Gods..., 230.

242 Daraki, «La mer dionysiaque», 8 ss. Según Pausanias (2.37.5) en la Argólida, junto a la fuente de Anfiarao, había una laguna llamada Alcionia a través de la cual Dionisio accedió al Hades para buscar a su madre.

243 Ath. 3.78c; H. Jeanmaire, Dionisos. Histoire du culte de Bacchus, París, 1978 (1951), 19, 221 ss.; F. Frontisi-Ducroix, Le dieu-masque. Une figure du Dionisos d'Athènes, París-Roma, 1991, 35.

244 Romero Recio, Cultos maritimos..., 49 ss.

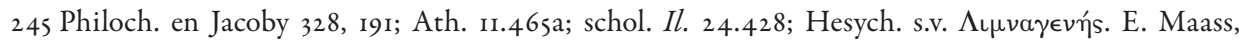

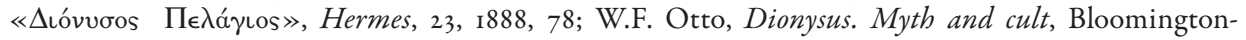
Londres, 1965, 163-164; Daraki, Dionysos, 32.

246Sobre la relación agua de mar-iniciación: H. Duchêne, «Initiation et élément marin en Grèce ancienne», en L'initiation, Actes du Colloque International de Montpellier 199I, II, Montpellier, I992, I32; B. D’Agostino, «Oinops Pontos. Il mare come alterità nella percezione arcaica», MEFRA, III.I, I999, I07-II7.

247 Paus. 9.20.4. 
infiernos que arrastra consigo a los difuntos y dios marino que llega en barco. Por tanto, no creo que puedan ser consideradas únicamente desde el punto de vista de una festividad de carácter funerario y/o agrario olvidando la tercera faceta. Se trataba más bien de una celebración que aunaba todos los matices del culto de Dioniso, una serie de cualidades que, por otra parte aparecen imbricadas también en otras divinidades. Y es que el mundo funerario permanece intrínsecamente unido a la religiosidad de los navegantes, incluso el marinero se compara con el enfermo pues ambos son víctimas de una experiencia semejante que les aproxima a la muerte ${ }^{248}$. Por otra parte, algunas divinidades y personajes marinos reúnen algunos de estos aspectos: por ejemplo, Afrodita fue venerada en el Quersoneso Táurico como una divinidad del mar y como protectora de las almas de los difuntos ${ }^{249}$, los Dioscuros -"guardianes del mar" y "salvaguardas de los navegantes”- aparecen en ambientes funerarios, el cortejo de las Nereidas -seres marinos por excelencia- acompañaba al difunto en muchas representaciones iconográficas, Deméter y Perséfone -deidades agrarias y ctónicas- aparecen frecuentemente junto a dioses marinos, la fundación de los Juegos Ístmicos se asocia a una muerte en el mar que culmina con la divinización del difunto o los héroes fallecidos en el piélago -Esténelo Actórida, Miseno, Frontis- son venerados por los navegantes ${ }^{250}$.

Del mismo modo, el vino no está tan alejado del mundo de la navegación si tenemos en cuenta que: ya en la Odisea aparece la asimilación de las aguas del mar con el vino y surge en la literatura la metáfora del simposio y el mar $^{251}$; los vasos para beber, como se ha señalado más arriba, llevan nombres de barcos; se emplea el vino en las libaciones rituales asociadas a la partida y llegada de $\operatorname{los} \operatorname{barcos}^{252}$ y algunos tipos de vino se preparaban con una mezcla de agua de $\operatorname{mar}^{253}$.

\footnotetext{
248 Romero Recio, Cultos maritimos..., II2.

249 S.Y. Saprykin, «Aphrodite with two erotes from Tauric Chersonese», Ancient Civilizations from Scythia to Siberia, 7, I-2, 2001, 99-122.

250 M. Romero Recio, «Conflictos entre la religiosidad familiar y la experiencia sacra de los navegantes griegos», ARYS, I, 1998, 39-50; Cultos maritimos..., 44 ss., 98 ss.

251 Od., I.I83; 4.474, etc.; W.J. Slater, «Symposium at Sea», HSPh, 80, 1976, I6I-170; M.I. Davies, «Sailing, rowing and sporting in one's cups on the wine-dark Sea», en Athens comes of Age from Solon to Salamis. Papers of a Symposium sponsored by the Archaeological Institute of America and the Department of Art and Archaeology, Princeton (New Jersey), 1978, 72-95.

252 Romero Recio, Cultos maritimos..., 106.

253 Davies, «Sailing, rowing and sporting in one’s cups on the wine-dark Sea», 73-74.
} 
Considerando los datos expuestos, no creo que pueda subestimarse -o incluso negar ${ }^{254}$ - el hecho de que Dioniso se pasee en barco durante la fiesta de las Antesterias, sobre todo si añadimos el hecho de que en algunos lugares como en Hermíone -una zona costera donde existen otros cultos vinculados a la navegación como los de Afrodita Pontia y Limenia, Posidón y Ártemis Ifigenia- se celebraron competiciones de natación y navales en su honor ${ }^{255}$. Las competiciones navales aparecen en distintas festividades del mundo griego, asociadas a divinidades de los navegantes y en un contexto que difícilmente puede alejarse de las formas de competición ritualizada propias de este grupo social. Puesto que no era inusual que las naves de guerra compitiesen durante la navegación (Th. 6.32; X. Hell. 6.2.28; Arr. An. 23.5), sería bastante razonable que estos mismos barcos participasen en regatas, que se enmarcaban en unas festividades en honor de una divinidad marina, y en las cuales podían poner públicamente de manifiesto su valía. Algunas celebraciones de este tipo ya han sido mencionadas, como las que tenían lugar en Sunio, en el Pireo, en Corcira, en Corinto y en Léucade ${ }^{256}$. Por otra parte, sabemos gracias a Pausanias (I.28.II) que en el Pireo los barcos se empleaban no sólo en actividades enmarcadas dentro de celebraciones religiosas, sino también en otras prácticas ajenas a la navegación como las causas judiciales, pues cuenta que en Fretáis, los acusados pronunciaban su defensa desde una nave ante los jueces que les escuchaban desde la tierra.

Dioniso se relaciona, por tanto, con los viajes marítimos a través de diferentes vías y las Antesterias, unas fiestas que tienen lugar hacia el final del invierno, vinculan esta faceta con las restantes esferas de influencia de la divinidad que aglutina de este modo todas sus cualidades ${ }^{257}$. No quiero decir, por tanto, que las Antesterias sean unas fiestas gestadas y desarrolladas únicamente en ámbito náutico, sino que se trata de una festividad que incluye, entre otros elementos básicos, por una parte, la referencia a una actividad fundamental que garantiza la comunicación de la comunidad con el exterior y la llegada de abastecimientos, la navegación, y por otra, la alusión, como apunta Parker, a que un dios puede disponer de la facultad de viajar por mar incluso fuera de la temporada naviera ${ }^{258}$ y que puede hacer frente a los peligros llegados desde el mar -como, aunque

254 Humphreys (The Strangeness of Gods..., 230-23I) no cree que las cerámicas de figuras negras del s. VI donde aparece Dioniso sobre el barco puedan vincularse directamente con las Antesterias y tampoco encuentra el vínculo entre la llegada de Dioniso por mar y la fiesta.

255 Paus. 2.34.I0-II; 35.I. Cf. Romero Recio, Cultos maritimos..., 72.

256 Véase, Gardner, «Boat-Races...», 90-97; Harris, Sport in Greece and Rome, I12, 127.

257 Nilsson ya apuntó (Martini P. Nilsson Opuscula Selecta, I, Lund, I951, 23) que la fiesta podría vincularse a la apertura de la estación navegable, aunque más tarde rechazó esta idea (Opuscula Selecta, I, 205). 258 Parker, Polytheism and Society..., 303. 
no sólo como plantearé a continuación, a los piratas a los que el propio Dioniso debe enfrentarse- en cualquier época del año y más aún cuando se aproxima el buen tiempo.

No debemos olvidar que los ataques de piratas eran frecuentes y que incluso pudieron ser los responsables de la primera reorganización del Ática llevada a cabo por Cécrope como una medida de protección frente a las amenazas por mar de los carios y por tierra de los beocios (aoni) ${ }^{259}$. De hecho, se pensaba que durante las Antesterias las almas de los difuntos -keres o carios- llegaban por mar hasta que eran expulsadas de nuevo al finalizar esta fiesta. Algunos autores han pensado que estos keres/carios podrían ser el recuerdo de los primeros habitantes del Ática ${ }^{260}$, poblaciones cercanas que practicaban razzias costeras; sin embargo, me parece factible plantear, que en las Antesterias pudiera haberse producido una simbiosis entre los carios, comunidades que ejercían la piratería tal y como aparece representada en los textos homéricos, y que evidentemente suponían un peligro para los asentamientos costeros, y los espíritus de los náufragos no sepultados que vagaban por el mar. Si el miedo a los difuntos era general, aún más lo sería hacia los navegantes muertos que, conocedores de todos los secretos del piélago, contarían con la posibilidad de acosar a aquellos parientes que no les hubiesen prestado las debidas atenciones de modo que pudiesen provocar, asimismo, su muerte en el mar. Es ésta la sensación que parece transmitir Propercio en una de sus elegías: "Volved su cuerpo a tierra, su vida yace en el abismo; vil arena, cubre a Peto con tu propio movimiento; y cada vez que un marino pase frente al sepulcro de Peto, diga: “Tu puedes atemorizar aún al audaz" (3.7. 25-28) ${ }^{261}$. Así pues, creo que precisamente Dioniso que, como hemos visto, aglutina características propias del mundo funerario y náutico, podía funcionar adecuadamante como una divinidad que al finalizar las Antesterias expulsase con la frase “FFuera, Keres, la Antesteria ha terminado!”, la amenaza que podía llegar por mar tanto desde el mundo de los vivos como desde el mundo de los muertos.

Otra fiesta en la que se celebra una procesión con un barco son las Panateneas, la festividad más importante de Atenas. Éstas tenían lugar en plena estación navegable, durante el mes que abría el año ateniense, Hecatombeón (julio/agosto). La fiesta se prolongaba durante varios días, pero el más importante era el 28 , cuando tenía lugar la procesión desde el Cerámico, la ofrenda del peplo a la diosa y los principales sacrificos.

259 Robertson, Festival and legends, 58 ss.; M. Valdés, «El proceso de sinecismo del Ática: cultos, mitos y rituales en la 'primera polis' de Atenas», Gerión, 19, 2001, 139-1 42.

260 Burkert, Homo Necans, 266 ss.

26I Romero Recio, «Conflictos entre la religiosidad familiar ...», 39-50. 
El origen de esta fiesta continúa siendo motivo de discusión aunque prácticamente toda la investigación coincide en su antigüedad pues la tradición atribuye su fundación a Erictonio-Erecteo ${ }^{262} \mathrm{o}$ a Teseo ${ }^{263}$. Según Pausanias (8.2.I), primero fueron conocidas con el nombre de Ateneas para después pasar a llamarse Panateneas en tiempos de Teseo. Lo que está más claro es que la fiesta fue reorganizada por Pisístrato en el año 566 a.C. A partir de este momento habría unas Grandes Panateneas que se celebraban cada cuatro años -pentetéricas- y contaban con la participación de otras poleis y unas Pequeñas Panateneas anuales y más propiamente atenienses.

Durante las Panateneas los atenienses celebraban una procesión que iba desde las afueras de la ciudad hasta el centro ${ }^{264}$. Partía de las puertas del Dipilón, seguía por el Cerámico y el Ágora para ascender hacia la Acrópolis, y una vez atravesados los Propíleos rodeaba el Partenón hasta situarse en la parte Este del templo, frente al altar de la diosa Atenea. En un momento difícil de precisar, tal vez desde el mismo origen de la fiesta -si bien hay autores que lo situan en una época más tardía ${ }^{265}$-, se incluye en esta procesión el traslado del peplo de Atenea en un barco sobre ruedas que Pausanias indica que se enseñaba cerca del Areópago ${ }^{266}$. El peplo, teñido de azafrán, había sido tejido por las Ergastines y era el arconte-rey el encargado de revestir con él el xoanon de la diosa que se encontraba en el Erecteo. Como en otras grandes fiestas se celebraban también pruebas atléticas: carreras a pie, a caballo y de carros, carreras de antorchas, certámenes

262 Marm. Par. FGrH 239 A Io; Hyg., astr. 2.13; schol. Ael. Arist. Panath. 13.189.4-5. 263 Plu. Thes. 24. La bibliografía es abundante: J.A. Davison, «Notes on the Panathenaia», JHS, 78, 1958, 22-41; Parke, Festivals of the Athenians, 33 ss.; Simon, Festivals of Attica..., 55 ss.; Burkert, Homo Necans, 154 ss.; N. Robertson, «The Origin of the Panathenaea», Rheinisches Museum, I28, 1985, 231-295; Mansfield, The Robe of Athena...; V. Tracy, «The Panathenaic Festival and Games: An Epigraphic Enquiry», Nikephoros, 4, 1991, 133-153; P. Brulé, «Fêtes grecques: périodicité et initiation. Hyakinthies et Panathénées», en L'initiation, Actes du Colloque International de Montpellier 19gI, I, Montpellier, 1992, 19-38; J. Neils (eds.), Godess and Polis. The Panathenaic Festival in Ancient Athens, New Hampshire, 1992; J. Neils (Ed.), Worshipping Athena. Panathenaia \& Parthenon, Wisconsin, 1996; J.L. Shear, Polis and Panathenaia: the History and Development of Athena's Festival, diss. Pennsylvania 2001; Parker, Polytheism and Society..., 253 ss.

264 Sobre esta procesión: H. Gerding, «The Erechtheion and the Panathenaic Procession», AJA, iro, 2006, 389-40I. Cf. Cf. Th. I.20.2; 5.47; 6.56; Hld. I.IO.I.

265 N.A. Norman («The Panathenaic ship», ArchNews, I2, 3-4, 1983, 4I-46) cree que el barco aparece en las Panateneas a partir de Demetrio Poliorcetes, mientras que Shear (Polis and Panathenaia...) opina que a partir del 402-40I el peplo se llevaba sobre una especie de flotador que pasaría a tener forma de barco en época de Herodes Ático, hacia I42-I 43.

266 Paus. 1.29.1; Philostr. VS, 2.1.5; Stratt. fr. 30 CAF I.719; Him. 47.12-17; IG II/III'2198. Deubner, Attische Feste, 32-34; Tracy, «The Panathenaic Festival...», 133-153; E.J.W. Barber, «The peplos of Athena», en J. Neils (ed.), Godess and Polis..., I03-ıı7; Brulé, «Fêtes grecques...», 33. 
musicales, combates y, posiblemente, regatas ${ }^{267}$, lo cual implica, como ya he señalado, la actuación de sus más directos protegidos durante la travesía, los pilotos.

Se ha defendido una relación de la fiesta con varios aspectos: los juegos funerarios celebrados en honor de los miembros de las grandes familias aristocráticas ${ }^{268}$, la renovación y el ciclo agrario de la ciudad, la organización del ejército, el sinecismo de $\mathrm{Teseo}^{269}$. Sin duda todos aportan explicaciones convincentes aunque no creo que pueda desvincularse de ninguno de ellos el motivo del barco trasladando el peplo de la diosa y a su vez, el hecho de que este motivo deba relacionarse con el carácter marino de Atenea como guía y constructora de barcos. Algunos autores han defendido que la ofrenda del peplo debe ser muy antigua puesto que tanto las fuentes literarias como arqueológicas parecen corroborar la existencia de este tipo de ofrenda desde época micénica ${ }^{270}$. Ahora bien, la introducción del barco es un tema mucho más controvertido pues las fuentes son bastante más tardías. Puesto que la primera vez que se menciona es en un fragmento del comediógrafo Estratis en el s. V a.C., la mayor parte de los autores que han estudiado estas fiestas han defendido que la introducción del barco en las Panateneas se habría producido en esa centuria y, probablemente, tras la victoria de Salamina, coincidiendo con el ascenso del imperio naval ateniense ${ }^{271}$. Incluso se ha llegado a minimizar hasta tal punto la relación de la diosa Atenea con el mar y la navegación que se ha señalado, por ejemplo, que su vínculo con este ámbito prácticamente se limita a Sunio, donde puede aparecer como patrona de la aplicación de la tecnología a la navegación, o al hecho de que puede ser invocada como Salvadora, junto con Zeus, por algunas personas en apuros. En cuanto a los aspectos náuticos de las Panateneas, se ha conside-

267 Parke, Festivals of the Athenians, 43; Robertson, «The Origin of the Panathenaea», 266; Golden, Sport and society..., 8-9, I64; P. Palagia, «A Gymnasiarch's Dedication and the Panathenaic Torch-Race», en Agathos Daimon. Mythes et cultes. Études d'iconographie en l'honneur de Lilly Kabil, BCH suppl. 38 , París, 2000, 403-408. En concreto sobre las regatas: IG II² 2311.78-80; Gardner, «Boat-Races...», 93; P. Wilson, The Athenian Institution of the Khoregia, Cambridge, $2000,8$.

268 D.G. Kyle, Athletics in Ancient Athens, Leiden, 1987.

${ }_{26} 69$ La bibliografía sobre estas interpretaciones aparece recogida en: M. Valdés, Politica y religión en Atenas arcaica. La reorganización de la polis en época de Solón. Una revisión de la documentación arqueológica, literaria y religiosa, $B A R$, 1018 , Oxford 2002, 165 ss.

270 Il. 6.288-304; Robertson, «The Origin of the Panathenaea», 290; E. Simon, «Theseus and Athenian Festivals», en Neils (Ed.), Worshipping Athena..., 23.

27I Parke, Festivals of the Athenians, 39; Mansfield, The Robe of Athena..., 68; H.A. Shapiro, «Democracy and Imperialism. The Panathenaia in the Age of Perikles», en Neils (Ed.), Worshipping Athena..., 217; Parker, Polytheism and Society..., 262. Referencias del s. III: SEG XXVIII 60.64; IG II² 657.14-16. Pausanias (I.29.I) señala que cerca del Areópago se enseñaba la nave que se utilizaba en la procesión que se realizaba durante esta festividad. 
rado que derivan del carácter del festival como una ocasión de la completa exhibición cívica antes que de la propia naturaleza de la diosa ${ }^{272}$.

No puedo estar de acuerdo con esta interpretación pues, como ya he expuesto más arriba y tendré ocasión de volver a repetir en el siguiente apartado, creo que la relación de la diosa Atenea con el mar y la navegación está bien documentada y, además, desde una época antigua. Me inclino, por tanto, a defender que los aspectos náuticos de las Panateneas tienen que ver con la protección que la diosa ejercía en el mar sirviendo como guía y con su patronazgo sobre los constructores de barcos, y que ésta estaba integrada en la fiesta desde mucho antes de que tengamos constatada la presencia del barco. Es más, creo que las Panateneas, como las Cibernesias o las Plinterias, eran fiestas muy antiguas que, también como éstas, habían integrado en sus rituales elementos vinculados a los viajes por mar pues, aunque se evitasen en la medida de lo posible, eran imprescindibles para la comunidad. Atenea había ganado la batalla por el control de Atenas al mismísimo Posidón, por lo que debía asumir la protección de los atenienses en el mar frente a la violencia de un dios dispuesto siempre a provocar naufragios, de ahí también que los atenienses se mostrasen sumamente devotos de esta divinidad a la que agradecían ofreciendo barcos su ayuda en las batallas navales. Por ejemplo, en conmemoración por la victoria obtenida en Salamina, los griegos dedicaron tres trirremes fenicias: una en el Istmo -que aún se conservaba en época de Heródoto- y otra en Sunio a Posidón, y la última a Áyax en la propia Salamina (Hdt. 8.12I).

Pero es que, además, creo que los relatos mitológicos nos ofrecen una buena muestra de que el origen y desarrollo de estas fiestas estaba perfectamente imbricado y que, como señalaba más arriba, en toda la zona costera que engloba Ática, Salamina, Eleusis y Nisea se desarrolló un complejo de correspondencias simbólicas y rituales en torno a Teseo, personajes con el nombre de Esciro, héroes navegantes y cultos relacionados con Atenea. Me refiero a que, Erictonio, a quien una de las versiones atribuye la fundación de las Panateneas, es hijo de Hefesto y la Tierra pero por mediación de Atenea. Según el mito, Hefesto se había enamorado de Atenea e intentó violarla. La diosa logró escapar pero con el semen de Hefesto en una de sus piernas. Después de habérselo limpiado con lana, arrojó ésta al suelo, de donde nació -al contacto con la fértil tierra- Erictonio a quien la divinidad tomaba por su propio hijo. En algunas versiones, Erictonio va a ser quien provoque la huida enloquecida de Pándroso y sus hermanas que hemos mencionado brevemente más arriba a propósito de las Plinterias.

272 Parker, Polytheism and Society..., $4 \mathrm{IO}$. 
Es decir, encontramos muchas correspondencias mitológicas entre estas fiestas en las que se observan diferentes aspectos vinculados con el mar y la navegación, por lo que parece plausible que todas ellas tengan si no en exclusiva, al menos en gran parte, una relación con el ritmo de esta actividad. Así pues, del mismo modo que las Plinterias podrían, desde otra perspectiva, renovar los poderes de Atenea en el mar, las Panateneas podrían mostrar, en un momento álgido de la estación navegable, en el primer mes del año, cuando el buen tiempo garantiza las comunicaciones marítimas, el poder de la diosa en este medio. Precisamente, como ya he subrayado, todavía en la actualidad, la fiesta más importante de la Virgen protectora de los marineros, la del Carmen, se celebra en el mes de julio.

El elemento del barco en la procesión de las Panateneas creo que puede haber estado presente desde mucho antes del siglo $\mathrm{V}$ porque precisamente la intervención de la diosa en los quehaceres de los navegantes es una constante en la mitología. En cualquier caso, que se potencie después de la batalla de Salamina tampoco me parecería extraño, si bien, como apuntaba al hablar de la fiesta de Ártemis Muniquia, no creo que el carácter "marinero" de la fiesta se desarrolle a partir de la victoria de Salamina sino más bien al contrario. Dado que Atenea ya se asociaba al mar en esta fiesta se destacan aun más, en un momento de desarrollo de la armada, los elementos asociados a este ámbito, elementos que podrían haber estado en un segundo plano durante una buena parte de la época arcaica a consecuencia, de nuevo, de la caída en desgracia de la actividad náutica para las elites sociales. Así pues, el vínculo de las Panateneas con la navegación creo que viene corroborado, además de por la presencia del barco en la procesión y la tradición en este sentido de la diosa, por la celebración de regatas e incluso por las carreras de antorchas que en su paso por el Cerámico ${ }^{273}$ podían recordar a aquellos aristoi que se habían hecho enterrar en tumbas marcadas por grandes vasos decorados con los barcos en los que habían desarrollado su actividad pirática con el auxilio de Atenea.

\section{II.4. Fiestas en torno a la clausura de la temporada naviera}

Cuando en el apartado I.r me detenía en el estudio de las Cibernesias ya apuntaba la existencia de unas fiestas que, según mi punto de vista, marcaban el fin de la estación navegable. Se trata de las Pianopsias y las Oscoforias, celebradas ambas en el mes de Pianopsión (octubre/noviembre).

273 El paso por el Cerámico de las carreras de antorchas está corroborado por distintos documentos recogidos por Palagia, «A Gymnasiarch’s Dedication ...», 404 . 
El día 7 de Pianopsión se celebraba una fiesta consagrada a Apolo, las Pianopsias, conmemorando el regreso de Teseo de su aventura cretense ${ }^{274}$. Esta festividad también está constatada, como venimos comprobando que sucede con otras fiestas, en Tórico, donde probablemente tendrían lugar después de la celebración de las Pianopsias atenienses ${ }^{275}$. El acto principal y mejor atestiguado era la ofrenda de la eiresione -rama de olivo rodeada de lana y cargada de frutos- que realizaba por un muchacho, cuyo padre y madre estuviesen vivos, en el templo de Apolo Delfinio en Atenas.

Como indicaba más arriba, por consejo de Apolo, Teseo había elegido a Afrodita como compañera de viaje pues éste, a pesar de ser un dios vinculado al mar, no actuaba personalmente como protector durante la navegación. Por esta razón, bajo mi punto de vista, las Pianopsias conmemorarían la última muestra de agradecimiento que Teseo habría realizado a la divinidad que le había otorgado los instrumentos necesarios para llevar a buen fin su viaje.

Íntimamente conectadas con las Pianopsias, y entremezcladas en el relato de Plutarco sobre la aventura de Teseo, encontramos las Oscoforias que se celebraban aproximadamente entre los días 6 y 8 de Pianopsión ${ }^{276}$. El acto principal de la fiesta consistía en una procesión que iba desde el templo de Dioniso en Atenas al de Atenea Escírada en Falero ${ }^{277}$. En esta procesión participaban dos jóvenes pertenecientes a familias principales de la ciudad, portando ramas de viña. El aition de la fiesta según las fuentes era la llegada de Teseo a Atenas y la muerte de su padre, y precisamente el retorno del héroe coincide con un suceso dramático vinculado al mar. Cuando Teseo zarpa hacia Creta su barco llevaba velas negras, que habría de cambiar por otras blancas si regresaba a salvo; sin embargo, al volver a Atenas olvidó sustituirlas y su padre Egeo, pensando que Teseo había muerto, se suicidó ${ }^{278}$.

Resulta interesante que el regreso de Teseo coincida con la celebración de unas fiestas, las Oscoforias, que, mediante una procesión, establecen un nexo entre

\footnotetext{
274 Harpocr. $\pi$ I20; Plus. Thes. 2.4; cf. Sokolowski, LSCG, 1969, 7.8-19; 52, 1. 9; Mikalson, The sacred and civil calendar..., 69-70; Parker, Polytheism and Society...,185, 204-206, 480.

275 Lupu, Greek Sacred Law..., 1.27, pp. 122, 136.

276 Ferguson, «The Salaminioi of Heptaphylai...», 27 (el día 6); Simon, Festivals of Attica..., 89 y Parker, Athenian Religion..., 315-316 (el día 7); Mikalson, The sacred and civil calendar..., 7I (el día 8).

277 Plu. Thes. 22.2-4; Procl. Chrest. Ap. Phot. Bibl., 239, p. 322a. Cf. Parke, Festivals of the Athenians, 77 ss.; E. Kadletz, «The race and procession of the Athenian Oscophoroi», GRBS, 21, 1980, 363-371; Simon, Festivals of Attica..., 89 ss.; I.C. Rutherford, J.A.D. Irvine, «The race in the Athenian Oschophoria and a Oschophoricon by Pindar», ZPE, 72, 1988, 43-51; Parker, Polytheism and Society..., 21-217. 278 Apollod. epit. 1.7, 10; Plu. Thes. 17.4-5; 22.1; D.S. 4.61.4, 6-7; Paus. I.22. 5; Hyg. fab. 41.3; 43.2.
} 
dos divinidades asociadas al mar -Dioniso y Atenea- y en las que participaban unos remeros $^{279}$. Y es que Dioniso también se relaciona con el mito de Teseo, pues desposa a Ariadna cuando el héroe la abandona en Naxos, bien forzado por designios divinos, bien porque se había enamorado de otra ${ }^{280}$. Algunas tradiciones dicen que el dios la raptó, e incluso que Ariadna vivió con un sacerdote de Dioniso. Según otra versión, Ariadna (Plu. Thes. 20.4-7), después de haber sido dejada por Teseo en Amatunte porque estaba embarazada y no soportaba los avatares del oleaje, murió y fue enterrada en un lugar al que se llamó «de Ariadna Afrodita», lo que indica la existencia de un culto dedicado a la simbiosis de ambos personajes. Teseo regresó al lugar y encargó que hiciesen sacrificios en memoria de Ariadna y que se erigieran en su honor dos pequeñas estatuillas, una de plata y otra de bronce. Añade Plutarco, que el día 2 del mes Gorpieo (agosto/septiembre aproximadamente) los jóvenes imitaban a las parturientas dando gritos tumbados en el suelo. Curiosamente, también durante las Oscoforias atenienses dos chicos se vestían de mujer.

Como he defendido más arriba, en Atenas se celebraba en honor de Dioniso una festividad, las Antesterias, donde se conjugaban las distintas facetas del dios: divinidad agraria que trae el vino, deidad de los infiernos que arrastra consigo a los difuntos y dios marino que llega en barco. Pues bien, precisamente algunos autores han defendido una relación de las Oscoforias con la vendimia y la fertilidad ${ }^{281}$, por lo que considero plausible que también en estas fiestas que se celebran en torno a la clausura de la temporada naviera, Dioniso actuase como un dios agrario asociado al vino, pero también marino porque se vincula con la llegada de Teseo y de los infiernos porque precisamente el regreso feliz del héroe acarrea dos muertes, la de Ariadna y Egeo, éste último, además, arrojándose al mar.

Por otra parte, no debemos olvidar la otra deidad receptora de la procesión de las Oscoforias, Atenea Escírada, por cuya presencia algunos investigadores han pensado en una relación de la fiesta con la guerra y el matrimonio ${ }^{282}$. Verdaderamente esta suposición no me parece contradictoria pues ya he tenido ocasión de señalar un considerable número de ejemplos en los que algunas divinidades pueden actuar como protectoras de

279 Sokolowski, $L S C G$, n. 19, 1. 46; FGrH, 323a-334.

280 Hes. Th. 947-949; Plu. Thes. 20.1; Apollod. epit. 1.9; D.S. 4.60.4; Ov. fast. 3.460 ss.; Paus. 1.20.3; 10.29.4; Hyg. fab. I 4, 42-43; Astr. 2.5.

281 Jacoby en $F G r H$, 1954, I, p. 303; Parke, Festivals of the Athenians, I60-I6I; Ferguson, «The Salaminioi of Heptaphylai...», 40 .

282 I. Chirassi Colombo, «Paides e Guniakes: nota per una tassonomia del comportamento rituale nella cultura attica», QU, 30, 1979, 31; P. Vidal-Naquet, Le chasseur noir. Formes de pensée et formes de société dans le monde grec, París, 1981, I66 ss.; Calame, Thésée et l'imaginaire athénien..., 344 ss. 
los navegantes ejerciendo también su auxilio sobre otros ámbitos que pudieran parecer en principio contradictorios como el matrimonio, la fertilidad agraria o la guerra. No sólo creo que estas atribuciones no resultan excluyentes, sino que defiendo que pueden resultar absolutamente compatibles y que apuntan en favor de un origen de estas fiestas en una época muy antigua cuando los que navegaban también controlaban la defensa y el abastecimiento a través del comercio prexis. De hecho, esta antigüedad ya ha sido defendida por autores como Simon, quien considera que tanto las Pianopsias como las Oscoforias pueden remontarse a la Edad del Bronce ${ }^{283}$.

Como ya he tenido ocasión de defender, la advocación Escírada está relacionada con los cultos marítimos de la zona costera del Ática. La Atenea Escírada salaminia probablemente estaría asociada a la actividad náutica antes de su llegada a Atenas, donde encontró unos cultos en el puerto que le permitieron adaptarse sin dificultad a una serie de celebraciones que se vendrían celebrando desde una época muy antigua. Además, resulta especialmente interesante la noticia que menciona que había sido el propio Teseo quien había moldeado la imagen de esta diosa utilizando una arcilla de color blanco, pues precisamente ese es el color con el que se identifican las diosas fosfóricas que auxilian a los navegantes desde las rocas "blancas" costeras. Pues bien, Atenea Escírada, junto con Esciro, recibe en Falero, un mes después de haberse celebrado las Oscoforias, en Maimacterión, un sacrificio que, desde mi punto de vista, forma parte de una celebración que cierra definitivamente la temporada naviera, inaugurada en Muniquión, y establece un sólido nexo entre Posidón, Atenea y sus más leales devotos, los timoneles, venerados junto a su santuario. Es más, se trata de una corroboración más del lazo que une a los pilotos con Posidón y Atenea y que encuentra su reflejo en santuarios como Sunio o Lindos ${ }^{284}$.

Aunque la estación navegable más larga finalizaba en noviembre, se tiene constancia de la realización de viajes marítimos durante el invierno, al menos desde finales de la época arcaica y comienzos de la clásica ${ }^{285}$. Así pues, y aunque las travesías realizadas durante esta estación fuesen esporádicas, deberían contar con la sanción divina cuyo reflejo tal vez se pueda encontrar en sacrificios como los realizados en Maimacterión. De hecho, se celebraron en distintos lugares del Egeo fiestas en honor de Posidón en invierno, las Posidea, y el mes que llevaba el nombre de esta divinidad

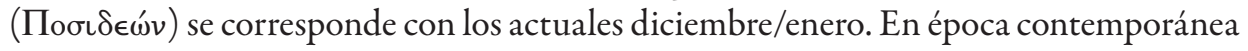

283 Simon, «Theseus and Athenian Festivals», 19.

284 Romero Recio, Cultos maritimos ..., i18.

285 Pind. I. 2.39-42; Thuc. 2.69; 3.88; 4.50; Xen. Ages. 2.31; Dem. Con. Dion. 30. 
también encontramos fiestas invernales asociadas a la navegación. Según Svoronos ${ }^{286}$, a finales del invierno los ortodoxos celebraban una fiesta -Phota- en la que los sacerdotes, para calmar el mar y cazar a los démones marinos, echaban a las aguas la cruz con la imagen de Cristo atada a una cuerda, lo que recuerda a la práctica de lanzar, en caso de naufragio, el ancla más pesada -«ancla sagrada»- en último lugar.

Así pues, no creo que, como afirma Robertson ${ }^{287}$, las fiestas invernales en honor de Posidón deban relacionarse únicamente con la fertilidad agraria -de nuevo la permanente exclusión que por defecto se lleva a cabo cuando se defiende un ámbito de actuación de los dioses- pues los lugares en los que se celebran (Tasos, Miconos, Egina, etcétera) están muy vinculados al mar y cuentan con otros cultos asociados a este medio. La intervención de las hetairas en algunas de estas fiestas es otro motivo que permite pensar en un nexo con el mar y la navegación, como ya he tratado de poner de relieve anteriormente. Además, la asociación de Deméter y Posidón en este tipo de festividades no necesita explicarse necesariamente desde el ámbito de los cultos agrarios pues, a mi modo de ver, las divinidades ctónicas también pueden aproximarse a la religiosidad de los navegantes.

Pero es que, además, creo que se pueden aportar otros ejemplos que muestran la existencia de otras fiestas que podrían relacionarse con la navegación fuera de la temporada naviera y que buscarían la protección de los dioses. Ya he tenido ocasión de aludir a las Antesterias, una festividad dedicada a dioniso a finales del invierno, pero existen otras, como por ejemplo, las Erosouria celebradas el día 9 del mes de Gamelión (enero/ febrero) en otro demo del Ática, Erquia ${ }^{288}$. El documento que alude a esta festividad data del s. IV a.C. y alude a un sacrificio realizado en honor de Atenea. Según Daux, la fiesta de las Erosouria estaría dedicada a los vientos favorables necesarios durante la navegación, pues su nombre deriva de oûpos, el viento favorable. De hecho, la advocación Oúpıos designa a Zeus como protector de los navegantes, el dios del «buen viento» que aparece en Esquilo (Supp. 594-595) y cuyo culto está constatado también en Siracusa ${ }^{289}$, y fue de gran importancia en Delos y en Calcedonia, a la entrada del Bósforo, en un templo que, según Pomponio Mela (I.I9.IOI), fue fundado por Jasón ${ }^{290}$.

$286 \ll$ Stylides, Ancres hierae...», I05 ss.

287 N. Robertson, «Poseidon's festival at the winter solstice», CQ, 34, I984, I-I6.

288 G. Daux, «La grande démarchie: un nouveau calendrier sacrificiel d'Attique (Erchia)», $B C H, 87$, 1963, 615 ss.; Sokolowski, $L S C G$, 1969, n. 18 b 1. 28-29.

289 IG XIV.574 (ép. helenística); Cic. Verr. 2.4.128. Cf. Inscriptions grecques dialectales de Sicile: contribution à l'étude du vocabulaire grec colonial, Roma, n. I88.

290 Delos: ID 1561, 2128, 2179, 2305 (s. II a.C.); Recherches sur les cultes de Délos à l'époque hellénistique et à l'époque impériale (BEFAR 217), París, 245-246. Calcedonia: Hdt. 4.87; Str. 12.4.2; Plb. 4.43; Plin. 
Así pues, creo que no sería extraño que la fiesta de las Erosouria tuviese unas connotaciones similares, sobre todo teniendo en cuenta que se celebra un sacrificio en honor de una divinidad marina, Atenea, y que en este lugar está también constatada la celebración de las Plinterias.

\section{Conclusiones}

Este trabajo ha tratado de evitar las descripciones de las festividades a las que se alude puesto que éstas han sido sobrada y ampliamente elaboradas por otros autores que aparecen citados en el aparato crítico. Mi pretensión a la hora de abordar el tema que planteaba en la introducción ha sido centrarme en los aspectos marinos de las fiestas mencionadas puesto que son los que habitualmente suelen pasar desapercibidos o relegados a un segundo plano en los trabajos de investigación. No he pretendido con ello defender que estos elementos marinos sean en todos los casos los que predominan en el origen de estas fiestas, sino subrayar cómo la defensa del carácter de una festividad no puede llevar a la negación de aspectos que, aunque en ocasiones secundarios en la información que ha llegado hasta nosotros, también pueden ser relevantes y que afectan al sentimiento religioso de un espectro importante de la población. Y es que, en general, la documentación de la que disponemos para conocer una fiesta pertenece a época clásica o helenística y tendemos a creer que las cosas han sido siempre como se describen en ese momento, pero, obviamente, esto no es así. Es posible rastrear la antigüedad de una fiesta a través de diferentes elementos, pero incluso aunque no diésemos con ellos tampoco estaríamos en disposición de negar tajantemente su existencia.

Creo que es necesario aceptar como premisa que la navegación, como cualquier otra actividad, estaba marcada por una serie de fiestas. Y una vez aceptada esa premisa no puede quedar otra alternativa que buscar esas festividades que difícilmente pueden reducirse a una celebración constatada en época tardía como el Navigium Isidis y a una fiesta bastante marginal como las Cibernesias. Las fuentes literarias y arqueológicas apuntan en otra dirección pues nos permiten constatar la existencia de elementos asociados al mar y la navegación en los rituales y celebraciones dedicados a algunos dioses que no sólo se relacionan con este ámbito a través de su corpus mitológico, sino que también fueron venerados por los viajeros gracias a la ayuda que podían prestar durante la travesía.

nat. 5.1 49; Arr. Peripl.M.Eux. 37 GGM; Philostr. VS I.24.I; Pseud. Scyl. 92 GGM; Ptol. 5.I.2; L. Robert, «Amulettes grecques», JS, 1981, 24; F. Cordano, «Due note Adriatiche», Hesperia. Studi sulla Grecità di Occidente, 3, 1993, 150-153. 
A lo largo de estas páginas he tratado de incidir en una serie de elementos que, en mi opinión, puede ayudar a entender mejor el calendario ritual griego, sobre todo el que estuvo en uso en la región del Ática. Esos elementos son: la antigüedad de las fiestas a las que se alude -exceptuando el caso del Navigium Isidis que, por otra parte, hubo de tener sus antecedentes en otras festividades dedicadas a divinidades propiamente griegas-, la existencia de elementos asociados al mar en estas celebraciones y el vínculo de las deidades a las que están dedicadas con la navegación.

El estudio de las fiestas que he abordado permite observar cómo se produce una simbiosis de elementos variados que, bajo mi punto de vista, vienen a reforzar el carácter antiguo de estas celebraciones pues tienen su génesis en un momento en el que las diferentes tareas no estaban tan netamente diferenciadas y donde la navegación asociada al abastecimiento se identificaba con las razzias piráticas practicadas por los nobles. Tengo la impresión de que a medida que el comercio prexis cede su lugar al comercio emporie y que los aristócratas se van desvinculando de la práctica comercial, los dioses se van desmarcando también de ese ámbito de actuación. Es por esta razón por la que, también a medida que la aristocracia se va desvinculando de celebraciones asociadas a la navegación como actividad indisolublemente unida al comercio, se va acercando más a la práctica marítima relacionada con la guerra, de ahí que, en un momento en el que la armada vaya cobrando mayor protagonismo, las divinidades retomen su carácter marino en algunas fiestas y se incorporen elementos que aluden a este ámbito.

Esto me lleva a defender que incluso aunque algunos de los elementos marinos de una fiesta puedan ser tardíos, se aplican en un momento en el que las batallas navales pueden ser decisivas en la victoria y se está fomentando el desarrollo de la armada, y eso se debe a que existe un poso cultual y cultural que reconoce el carácter marino de esas divinidades y de esas celebraciones y se exhibe públicamente en ese momento incorporando nuevos símbolos alusivos porque se asocia a los intereses generales de la ciudad y porque define a la ciudadanía. La navegación había perdido prestigio porque se vinculaba básicamente al comercio, pero después de las Guerras Médicas se "ennoblece" porque resulta imprescindible en la obtención de la victoria durante las campañas bélicas, de ahí la revitalización de fiestas que se vinculaban a la actividad náutica desde una época muy antigua.

Pero el nexo entre actividad náutica y armada no significa, evidentemente, la ruptura del lazo entre navegación y comercio. Las fiestas que hemos estudiado marcan la apertura, el desarrollo y la clausura de la temporada naviera lo que afecta a todas las actividades asociadas al mar, incluyendo claro está el transporte de personas y mercancías. Y así ha seguido siendo, como muestran las celebraciones asociadas a santos protectores 
de los marineros o a la Virgen del Carmen. Sin embargo, la estacionalidad de la navegación estaba mucho más marcada durante la Antigüedad griega por lo que la necesidad de establecer festividades que marcasen el ritmo de las travesías era todavía más necesaria, de ahí que encontremos un nutrido grupo de divinidades asociadas a este ámbito y un considerable número de fiestas que integran aspectos vinculados al mar incluso fuera de la temporada naviera. Estos elementos no pueden explicarse al margen de la navegación, ni pueden subestimarse pues las fuentes de las que disponemos, aunque puedan resultar escasas, permiten ofrecer una interpretación integradora.

Puede que, como planteaba al principio, haya sido la historiografía contemporánea la que ha infravalorado la actividad marítima/comercial ejercida por una clase social que no podía competir con la aristocracia propietaria de la tierra y, por tanto, promotora de una actividad mucho más digna. El estado actual de mi investigación al respecto no me permite confirmar este presupuesto, pero espero poder abordar esta cuestión en el futuro complementando este trabajo con un estudio historiográfico que creo que podrá arrojar luz sobre algunas cuestiones sobre las que no nos hemos parado a reflexionar porque, sin cuestionarlas, las hemos asumido como propias de la religión griega antigua. 